\title{
Liminal urbanity: Wars, connections and material culture in early modern Helsingborg
}

Amanda Sumner

ARKM22 Master's Thesis in Historical Archaeology

Department of Archaeology and Ancient History

Lund University

Spring 2021

Supervisor: Jonas Monié Nordin

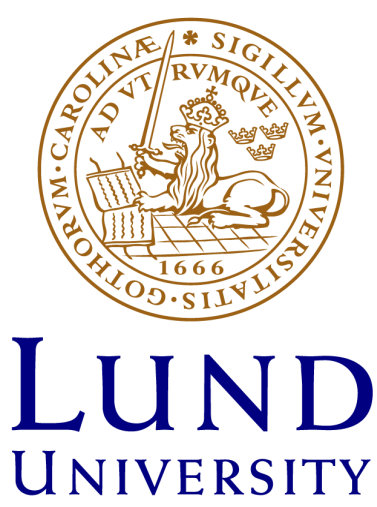




\begin{abstract}
In the 1600 s, Helsingborg was a small market town with great importance as a transport and trade connection between Scandinavia and the rest of Europe. Caught in the middle between two empires, Denmark and Sweden, the lives of Helsingborg residents were affected by wars, plagues and political disturbances. This thesis investigates the status of Helsingborg as a contested periphery town in relation to Helsingör on the other side of Öresund and in a wider southern Scandinavian context. Analysis of archaeological finds from six post-medieval sites in town centre, with primary focus on ceramics, examines how the material culture reflects urban consumption patterns, global trade connections and political changes. The results of the study demonstrate that Helsingborg in the 1600s was closely connected by trade and personal relationships to Helsingör.
\end{abstract}

Keywords: Helsingborg, early modern period, material culture, ceramics, consumption, global trade, conflict, world-systems. 


\section{Table of contents}

$\begin{array}{lr}\text { Introduction } & 4\end{array}$

$\begin{array}{ll}\text { Purpose and research questions } & 4\end{array}$

Theoretical perspectives and methods $\quad 5$

$\begin{array}{ll}\text { Background } & 7\end{array}$

$\begin{array}{ll}\text { Location and history } & 7\end{array}$

$\begin{array}{ll}\text { Helsingborg in the 1600s } & 7\end{array}$

Brief overview of urban archaeology in Helsingborg 18

$\begin{array}{ll}\text { Material } & 19\end{array}$

$\begin{array}{ll}\text { Post-medieval ceramics } & 19\end{array}$

$\begin{array}{ll}\text { Case studies of sites } & 23\end{array}$

$\begin{array}{ll}\text { Overview } & 23\end{array}$

Norden $24 \quad 26$

$\begin{array}{ll}\text { Finds from Norden } 24 & 28\end{array}$

$\begin{array}{lr}\text { Norden } 19 & 29\end{array}$

Finds from Norden $19 \quad 31$

Coin hoards from Norden block 33

Karl XI Södra 20

Finds from Karl XI Södra 20

$\begin{array}{ll}\text { Färjan } 4 & 40\end{array}$

Finds from Färjan $4 \quad 41$

$\begin{array}{ll}\text { Thalia } 8 & 44\end{array}$

Finds from Thalia $8 \quad 46$

$\begin{array}{ll}\text { Kärnan Mellersta } 9 & 48\end{array}$

Finds from Kärnan Mellersta $9 \quad 49$

Results and discussion $\quad 51$

$\begin{array}{ll}\text { Conclusion } & 56\end{array}$

$\begin{array}{ll}\text { References } & 57\end{array}$ 


\section{Introduction}

This thesis emerged from my work as a master's student at Helsingborg's Kulturmagasinet. My experience there introduced me to early modern ceramics and opened a window into the post-medieval town into which I eagerly climbed. Early modern Helsingborg was a liminal space - on the threshold between the land and the Sound, between being Danish and Swedish, a settlement that emerged to facilitate the movement. Helsingborg of 2021 can relate to Helsingborg of the 1600s in multiple ways; we share the topics of global pandemics and war refugees. During the past year we got a taste of what the residents of Helsingborg experienced in the 1680s when their family visits and shopping trips to Denmark were suddenly off limits. This thesis is shaped by the pandemic year, taking it into a direction I did not anticipate, thus emphasising the liminality of the research process.

In the past decade, Scandinavian archaeology has been turning its sights towards the post-medieval urban setting. Several major projects have emerged from this trend, among them the Nya Lödöse project and the Urban Diaspora project. Popular topics in post-medieval archaeology are urbanisation, cross-site consumption analysis and cultural interactions seen through the lens of materiality. Helsingborg seems to be often excluded from Swedish early modern cross-site studies because during the target time period it was located in Denmark and from Danish research because it now belongs in Sweden. My aim with this work is to bring early modern Helsingborg back into its Scandinavian and European context by means of material culture analysis while highlighting its organic connection with Helsingör which was disrupted by 17th-century politics.

\section{Purpose and research questions}

The purpose of this thesis is to gain an insight into life in early modern Helsingborg based on material culture, particularly on artefacts recovered during archaeological excavations. Earlier archaeological research in Helsingborg has focused on the medieval castle Kärnan and the Dominican monastery in the upper part of the town, remains of the churches of St. Clemens and St. Petri, as well as the extant St. Maria church including its cemetery and the nearby medieval residential blocks. In previously published research, less attention has been given to the development of the town in the post-medieval period and its role in connection with its sister town Helsingör on the other side of the Öresund. This study focuses on the part of the town which developed as a middle and upper class residential and commercial neighbourhood starting from the 1300s and its inhabitants, particularly the burgher households.

The purpose is guided by two research questions: the profile of Helsingborg as a Danish periphery town and a supply and transport hub with linked markets to Helsingör, and the political transition to a Swedish town post-war, consisting of several violent military campaigns and the destruction and rebuilding of the town centre.

What does the material culture of 1600s Helsingborg reveal about its status as a satellite town to Helsingör and how did that change after the Swedish takeover?

How is the transition to Swedish rule reflected in the material culture? 


\section{Theoretical perspectives and methods}

The main aim of this thesis is to place early modern Helsingborg within its regional and global context. For this purpose I have chosen to apply the framework of world-systems analysis. The key theoretical concepts I am using are world-system, core-periphery relationships, contested periphery, negotiated periphery and prestige goods.

World-systems analysis is based on the world-systems theory developed by Immanuel Wallerstein in the 1970s in the context of the rise of the capitalist world economy in the "long 16th century". To Wallerstein a world-system is not, in fact, the entire world but a self-contained socio-political unit, "an integrated zone of activity and institutions which obey certain systemic rules" (Wallerstein, 2004). While traditionally used mainly in regards to European empires and their colonies from the 1500s onwards, world-systems analysis can be applied to any such world-system at any point in history, on a larger or smaller scale - northwestern Europe, southern Scandinavia, the kingdoms of Denmark or Sweden. As an example of this nested hierarchy, Southern Scandinavia itself is often seen as a semiperiphery to its western European core, while Stockholm is the core to the early modern northern Fennoscandian periphery (Kuusela, Nurmi and Hakamäki, 2018).

The structure of a world-system, according to the original theory by Wallerstein, depends on an asymetrical relationship between its core and peripheries, with semiperipheries inbetween them, characterised by an unequal exchange. The cores exploit the perhipheries for resources and semiperipheries act as intermediaries. Since the 1970s, the world-systems analysis has undergone various modifications (Hall, Kardulias and Chase-Dunn, 2011). One of them is the distinction, proposed by Chase-Dunn and Hall (1997), between core-periphery hierarchy where one unit of the system dominates over others and core-periphery differentiation where the system works on the basis of equal interchange.

Chase-Dunn and Hall (1997) distinguish four types of core-periphery interaction - bulk goods network, prestige goods network, political and military network, and information network. While bulk goods network is usually localised, prestige goods can be exchanged over a larger, cross-cultural area. The four networks may or may not overlap, although information exchange is expected to follow along the prestige goods network.

Two more related concepts are relevant to this thesis. A border region is in its essence peripheral. A peripheral zone where two or more systems intersect or compete is considered a contested periphery. A contested periphery is a strategic location with economic or military action taking place over it (Hall, Kardulias and Chase-Dunn, 2011; Cline, 2000). While world-systems analysis can come across as an overly top-down approach, the concept of negotiated periphery adds human agency to a world-system where human agents negotiate their own level of incorporation and mutual benefits (Kardulias and Hall, 2008).

According to Galaty (2011), it is most often violence that sets in motion core shifts from one system to another. In regards to Helsingborg, we can talk about a systemic crisis in the mid-1600s which could not be resolved within the framework of the existing historical system. Scanians, subsisting in a contested periphery zone, were continuously fought over by Denmark and Sweden between the 1500s and the 1700s. The war between Denmark and Sweden was the violence that set the change in motion, and the transition of power to Sweden in 1658 left Helsingborg in an unstable position that continued for half a century. Helsingborg remained the periphery, and the core shifted from Denmark to Sweden, or so it would seem without a more 
in-depth look at the interactions on a local level. In the words of Immanuel Wallerstein (2004), "The period of transition from one system to another is a period of great struggle, of great uncertainty, and of great questioning about the structures of knowledge."

Although I propose that early modern Helsingborg acted as a periphery to Copenhagen, with Helsingör as their semiperiphery connection, based on the direction of the interaction networks, the exact nature of this core-periphery relationship is not immediately obvious. Helsingborg is older than Helsingör by centuries, the latter being founded in the 1420s, but it is unclear whether local agency was involved or whether it was a deliberate move from above to place Helsingborg in the periphery to Helsingör, acting as a supplier of bulk goods and transport as a commodity. Gosden (2004) links material culture to structures of power, making the connection between colonialism in a shared cultural milieu and the values of wealth, style and aesthetics. Analysing the material culture may clarify whether the population of Helsingborg had the agency to define their status in this core-periphery relationship as a mutually beneficial one, whether raw materials and bulk goods were routinely exchanged for prestige goods, and whether the prestige goods arrived via Helsingör or elsewhere.

While records exist of the import and export of bulk goods such as grain, meat, wine or fabric, accumulation of prestige goods by residents relies on individual connections and gifts as much as on trade imports. Due to the loss of the town archives in 1679 , the majority of data on household possessions in 1600s Helsingborg comes from archaeological sources. Ceramics, as the most abundant type of find that can also be analysed for provenience and date, is a suitable material for answering questions related to trade networks and social status of households. In this thesis I investigate whether the household ceramics in early modern Helsingborg were predominantly locally made or imported, where the imports came from, how the distribution varies among the case study sites and how it compares with the ceramic finds from Helsingör. 


\section{Background}

\section{Location and history}

Helsingborg is located on the western coast of Scania in southern Sweden. Its geographical position at the narrowest part of the Sound (Öresund), only $4 \mathrm{~km}$ from Denmark, on the main route of ships passing through from the Baltic to the North Sea, has made it an attractive location for a settlement since prehistoric times. The layout of the city closely follows its topography, with the lower and the upper parts of town being separated by Landborgen, a natural plateau which in the middle of town rises between 20 and $40 \mathrm{~m}$ above sea level. Ravines carved by retreating glaciers 13,000 years ago provide access from Landborgen to the Öresund shore. Inhabited since prehistoric times, the area is rich in mesolithic, neolithic, and bronze age finds and grave mounds. There are 230 mounds registered in the Helsingborg municipality (Jennbert, 2010). The Helsingborg area was inhabited during the Iron age and Viking age, with Filborna the largest settlement acting as a central place. Fishing and trade activities took place along the coastline.

Already in the Viking age Helsingborg linked the two sides of the Öresund. "There is a short crossing by the Baltic sea at Helsingborg where Zealand can be seen from Scania, a common haunt of vikings," wrote Adam of Bremen around the year 1070 (Jennbert, 2010). The lower town of Helsingborg grew around the coastal marketplace. The founding of Helsingborg as a town can be traced to a donation letter of Canute the Holy in 1085 (Aarhus Universitet, 2011). During the early middle ages, a castle and three churches - St. Clemens, St. Petri and St. Olof - were built on Landborgen. St. Nicolai dominican monastery was founded in 1275. The origins of St. Maria church in the lower town go back to the 1100-1200s. During the Reformation in the 1530 s, the upper town churches and monastery were closed and demolished. St. Maria remained as the only church in town and is still standing today as one of the two surviving medieval buildings, along with the castle tower Kärnan which was built in the early 1300s in place of an 1100s round sandstone tower (Wihlborg, 1981).

Helsingör on the other side of the Sound is first mentioned as a market town in 1231 (Appel, 2020). As part of the introduction of the Sound Toll, the Krogen fortress, later the Kronborg castle, was built at the narrowest part of the Sound in 1426, opposite Kärnan in Helsingborg. Denmark collected the Sound Toll from all ships passing through from 1429 until 1857 (Appel and Linaa, 2020). Öresund has always had an economic and symbolic importance to both Denmark and Sweden, as evidenced by the many military conflicts across the area, culminating in the Scanian war of $1676-1679$.

\section{Helsingborg in the 1600s}

"Helsingborg is a nice and good little market town," wrote Jens Laurits $\varnothing$ n Wolf in 1654 (Wolf, 1654). A visitor to Helsingborg in the first half of the 1600 s would have encountered a small but bustling lower town along the seashore and a castle on a steep hill above it, surrounded by a medieval ring wall (Figure 1). Two parallel streets led through the town from one end to the other, Adelgatan (later Storgatan) and Lilla gatan (now Kullagatan). Arriving from Landskrona or Malmö, one would have entered the town from the south into Storgatan, while travelling from Halland, Ängelholm or eastern Scania a road along a natural ravine descended from Landborgen into Strömmen, a street located near modern day Springpostgränden. An imaginary line divided the town into the north and the south parts, following a road downhill from the castle near the modern day Billeplatsen, to St. Maria church, and along Norra Kyrkogatan on its northern side to 
the shore, ending in a ship pier. St. Maria church was the focal point of the early $1600 \mathrm{~s}$ Helsingborg. The town hall was located directly to the south of it, the Latin school stood by the churchyard walls on the corner of Storgatan and Norra Kyrkogatan, and the town hospital was located between the church and the pier. The highlight of Storgatan, to the east of the church, was Billegården, the manor of the lord of the castle, Anders Steensen Bille. It was the only several-storey brick building in town and was surrounded by decorative gardens with water features. Twice a week on market days, Storgatan and the smaller streets around the church were filled with market stalls and shoppers (Johannesson, 1969b).

We know about the layout of the town and certain buildings from maps and letters of travellers, but we have only fragmentary knowledge about the lives of the people of Helsingborg before the mid-1600s. Almost nothing remains of the town archives from 1537-1658 after the old town hall was destroyed in 1679 during the Scanian war. The population of Helsingborg can be estimated from the 1637 tax rolls as approximately 1000-1400 people. This number consists of the 205 listed burghers, with their families, servants, priests, Crown officials, nobility, craftsmen and tradesmen, foreign merchants and diplomats, tenants, the poor and beggars. Copenhagen at the same time had a population of 23,000 and Helsingör around 4000 . Twenty-eight of the burghers were involved in town administration and were merchants. Another 174 were in crafts and trades. This ratio is characteristic of medium-sized Danish towns in the 1500-1600s (Johannesson, 1969b, p. 35).

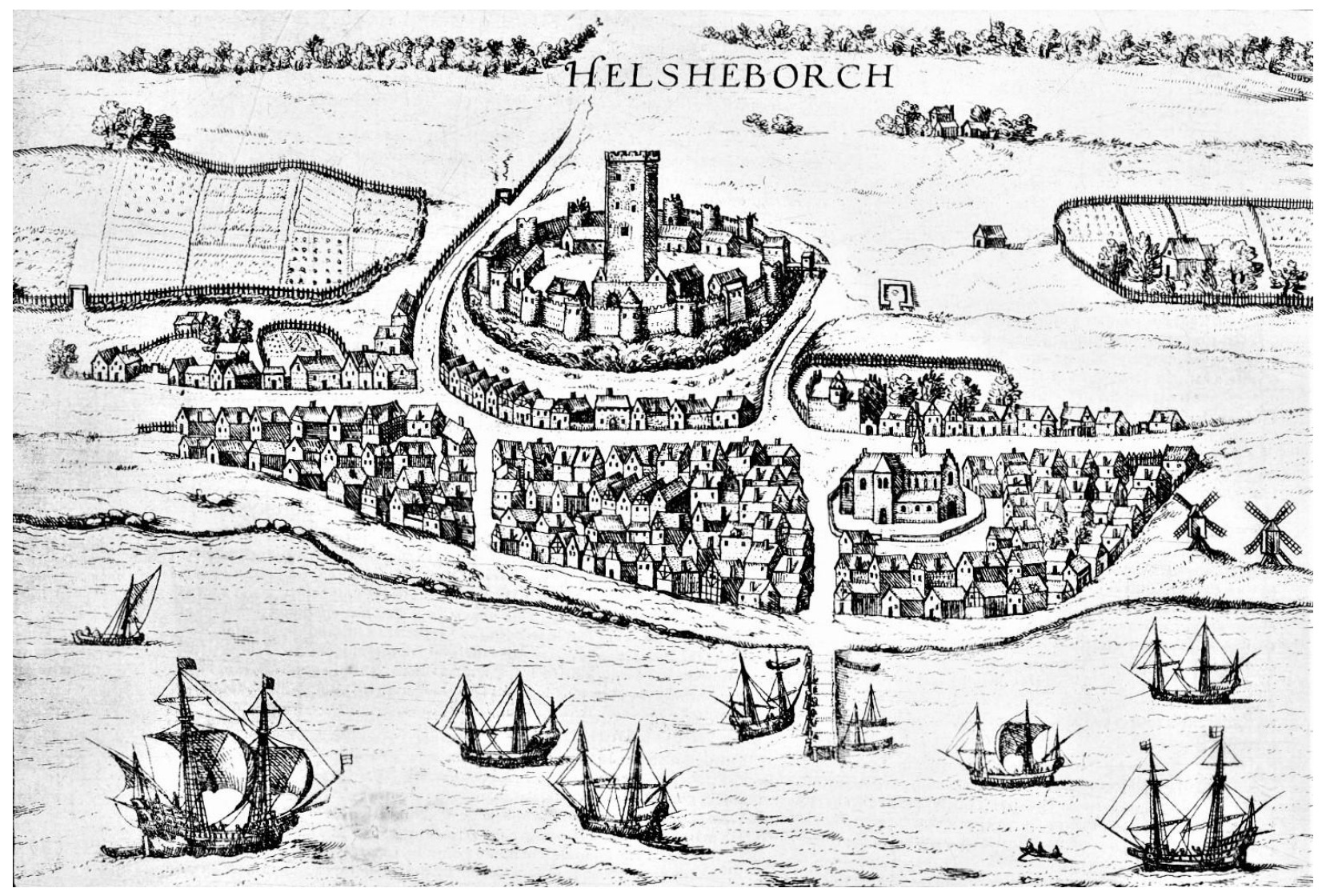

Figure 1: the earliest image of Helsingborg. Braun and Hogenberg, Urbium praecipuarum totius mundi, 1588. 
Burghers were property owners and merchants who could be elected to the town council and hold administrative posts. They could be untitled middle class or titled nobility (Hansen, 2020). Among the burghers were women, some on their own merits and others as widows of burghers. The town council in the first half of the 1600s had two mayors (borgmästare) and four to six aldermen (rådman). The alderman position was unpaid; they had to rely on their own business for income. Despite an annual rotation of council positions, the administration of Helsingborg was essentially a merchant oligarchy (Johannesson, 1969a, p. 21). Most of the burghers in Helsingborg were Danish; however, some were of foreign origin. The Ennes family descended from the Innes of Scotland. The Forbes were Scottish, the textile merchant Primroes English or Scottish. Others came from Germany, Flanders, the Netherlands, and Norway. Migration in and out of town was a common occurrence; those who left Helsingborg most often moved to Helsingör or other Scanian towns.

By a royal decree of 1561, the King's vassal and lord of the castle, or länsman, was the intermediary between the Crown and the town council, acting essentially as a governor. A länsman was a member of the higher aristocracy (Hansen, 2020). He could enact the King's orders and override decisions of the aldermen. The most influential länsmen of Helsingborg in the 1600s were Anders Steensen Bille (1610-1629) (Figure 2), Christoffer Ulfeldt (1629-1649), and Ove Giedde (1650-1658) (Figure 3).

Helsingborg was a small town with a high military and transit value. The oldest Helsingborg charter from 1414 already mentions the responsibility of burghers to keep the ferries between Helsingborg and Zealand running. Although Helsingör owned a few ferries, the business on their side was not as profitable. Cattle export to Denmark and from there to the rest of Europe provided a significant income to Helsingborg. By a 1640 royal decree, for every horse and ox shipped from Skåne, Halland, or Blekinge, a tax was paid for the Helsingborg ship pier upkeep. Although ferries also ran from Helsingborg to Copenhagen and connected other Scanian towns to the capital, the route between Helsingborg and Helsingör was the main cargo and passenger highway between Scania, Norway, and Sweden and the rest of Europe. A Crown letter granted its holder a free passage on the ferry. Similarly, a Crown letter granted a free ride out of Helsingborg. Carts for this purpose were owned by burghers and rented out on request. There were several attempts starting in the 1500 s to organise a postal service but at first it was limited to the Crown needs. The first official Danish postal lines opened in 1624, connecting Copenhagen to Helsingör, to Helsingborg, to Falkenberg, via Laholm and Halmstad. From there the connection extended to Norway. Meanwhile, the Swedish postal service founded in 1636 carried its mail to Markaryd where it was exchanged with the Danish post. A burgher was assigned in each town to collect letters and pass them on to the postal service. The post passed through once a week. Helsingborg was exempt from paying for the postal service; it recompensed by providing the ferry services (Johannesson, 1969b, p. 94).

Most of the town was in some way involved in facilitating travel and hospitality. By a 1537 decree, the mayor and the council in each town had to identify a few burghers who had the ability to open lodging, providing food, drink, horse feed, good beds, and good stable room. A sign had to be hung outside their house. Updates to this regulation were issued in 1611 and 1643 , freeing lodging providers from all tax and debt to the city. The King himself stayed in the Helsingborg castle for a night or two on his travels, while his retinue and horses were lodged in town. Travelling nobility also usually but not always stayed at the castle. Foreign diplomats, including Russian and French ambassadors, with entire delegations regularly stopped over in Helsingborg. In 1632, two Russian ambassadors stayed in town with a delegation of 60 people. 


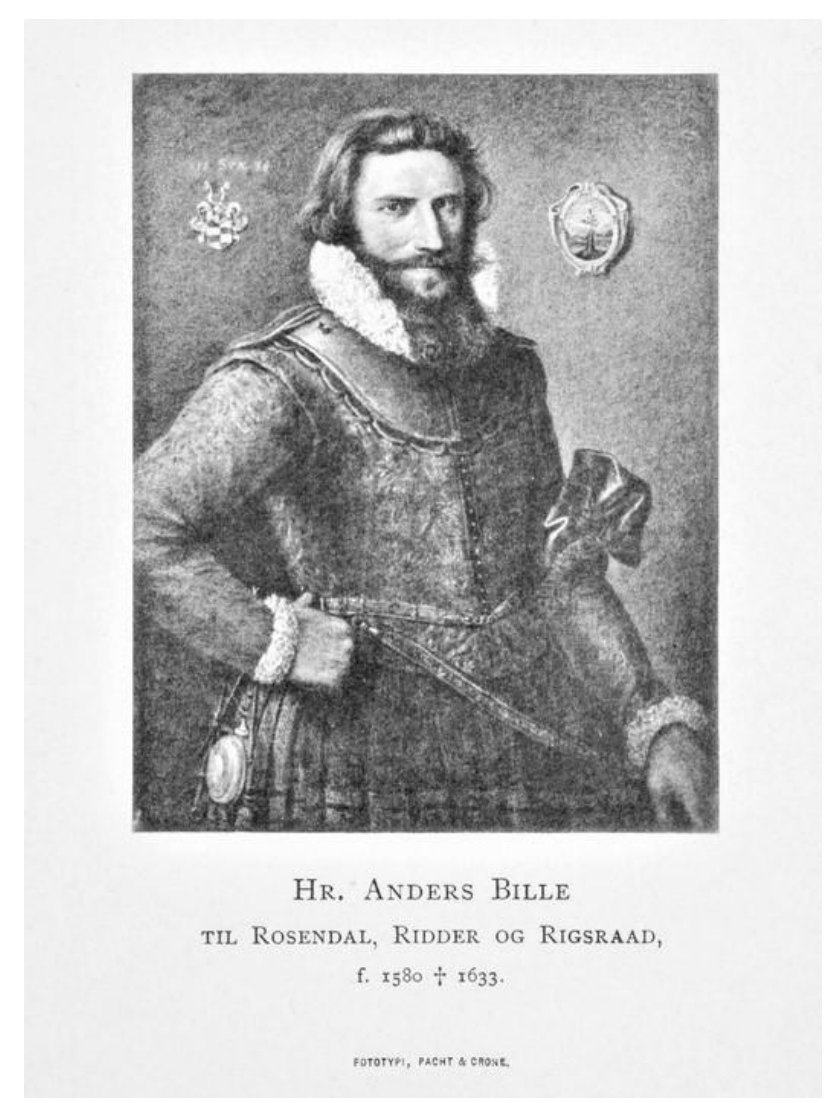

Figure 2: Anders Steensen Bille (1580-1633). Helsingborgs museum.

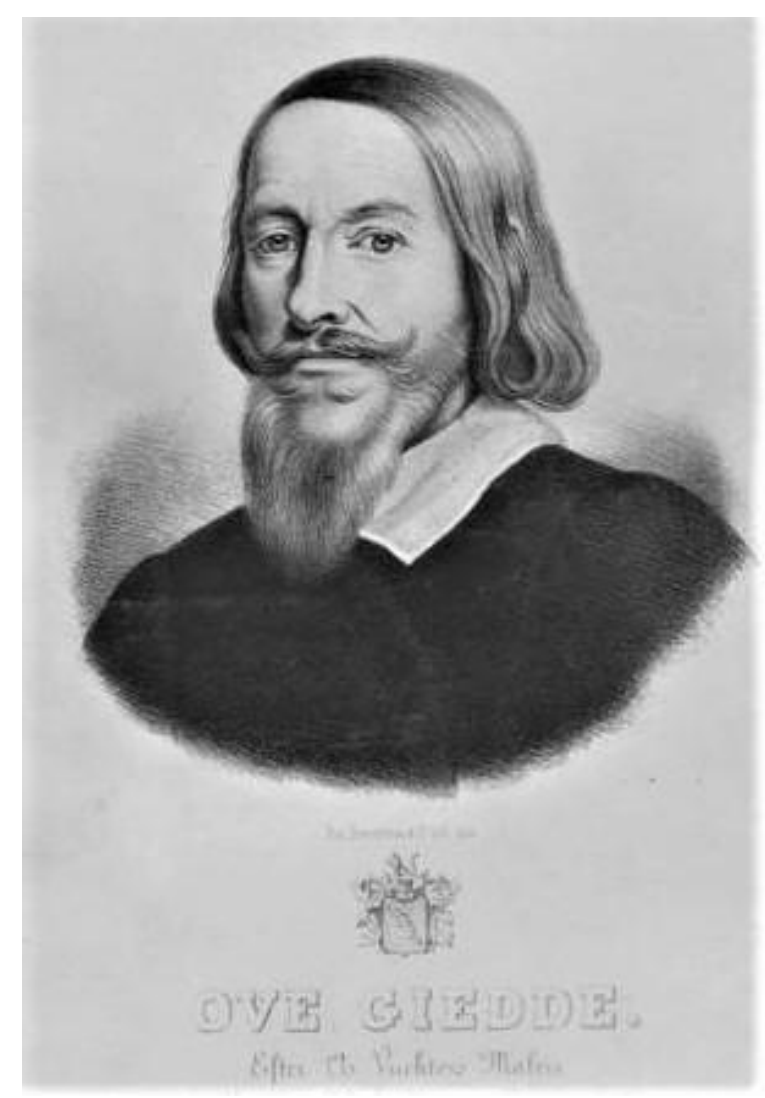

Figure 3: Ove Giedde (1594-1660). Helsingborgs museum.

At the same time, the town tried to keep out undesirable persons, beggars and vagabonds. Ferrymen were forbidden to carry across the above or any man or woman who did not have written evidence showing where they came from (Johannesson, 1969b, p. 99).

The Danish market town ordinance from 1422 set detailed rules for who could sell and buy and where. A craftsperson should live on the income from their craft and not do other business. The town folk who were not craftspeople should engage in trade and brewing. Craftsmanship should be concentrated in towns. The trade of goods outside of market towns was strictly forbidden, giving market towns a monopoly on trade, with the exception of trading with ships anchored on the Öresund. Danish nobility as well as citizens of Helsingör, Helsingborg, Copenhagen, Landskrona, and Malmö were allowed to sell and buy from the ships but only by the whole boatload (Johannesson, 1969b, p. 122). Merchants who were not burghers in the market town came to market days as "guests". Guest merchants had to lodge with burghers and were allowed to buy only what was required for their own use and not for resale elsewhere. They could sell their own goods only to the burghers of the town. Special rules applied to Helsingör's burghers who were not considered "guests" in Helsingborg. The Helsingborg/Helsingör common market was unique in Denmark. Helsingör's market space was limited, therefore the burghers were given the rights to shop at Helsingborg, as well as at Isefjord and Limfjord. Helsingborg's burghers in return had the right to freely trade in Helsingör. In market terms this made them one town, with two administrations (Johannesson, 1969b, p. 117). The common market continued until 1658 and the loss of it had a major impact on both towns' economies. 
The troubles in Helsingborg started during the 1643-1645 Swedish-Danish war. The town was occupied by Swedish troops from February 1644 to September 1645 . Swedes reenforced the castle walls and built a half-bastion in front of the castle entrance (Roth, 2020). A large number of burghers evacuated to Helsingör at the approach of the Swedish army, leaving parts of town abandoned. Swedish troops looted the empty town, damaging the buildings. After the war, the residents returned and faced a cleanup. An inventory of town buildings found damage to 113 properties. Fifteen houses were completely ruined and three houses had been moved up the hill to the castle walls. One of the three relocated houses was eventually left at the castle and incorporated into its fortifications (Johannesson, 1969c, p. 201).

The work on a modern fortification system to better defend the town began in 1650. A system of bastions and walls was built around the town, including along the shoreline (Mårtensson, 1969b). The local garrison held 34 soldiers at the time. Their numbers were boosted by between 80 and 150 Norwegian soldiers and 350 men from the Zealand regiment who were ordered to Helsingborg for construction work. Crown peasants from as far away as Lund were ordered to deliver stone and timber. Quartering of troops and construction work in town had already made burghers' lives rather unpleasant when a plague hit the overcrowded town in 1654. Nearly half of the population died. In 1657, Helsingborg had only 120 burghers, compared to 205 in 1637 (Johannesson, 1969b, p. 38).

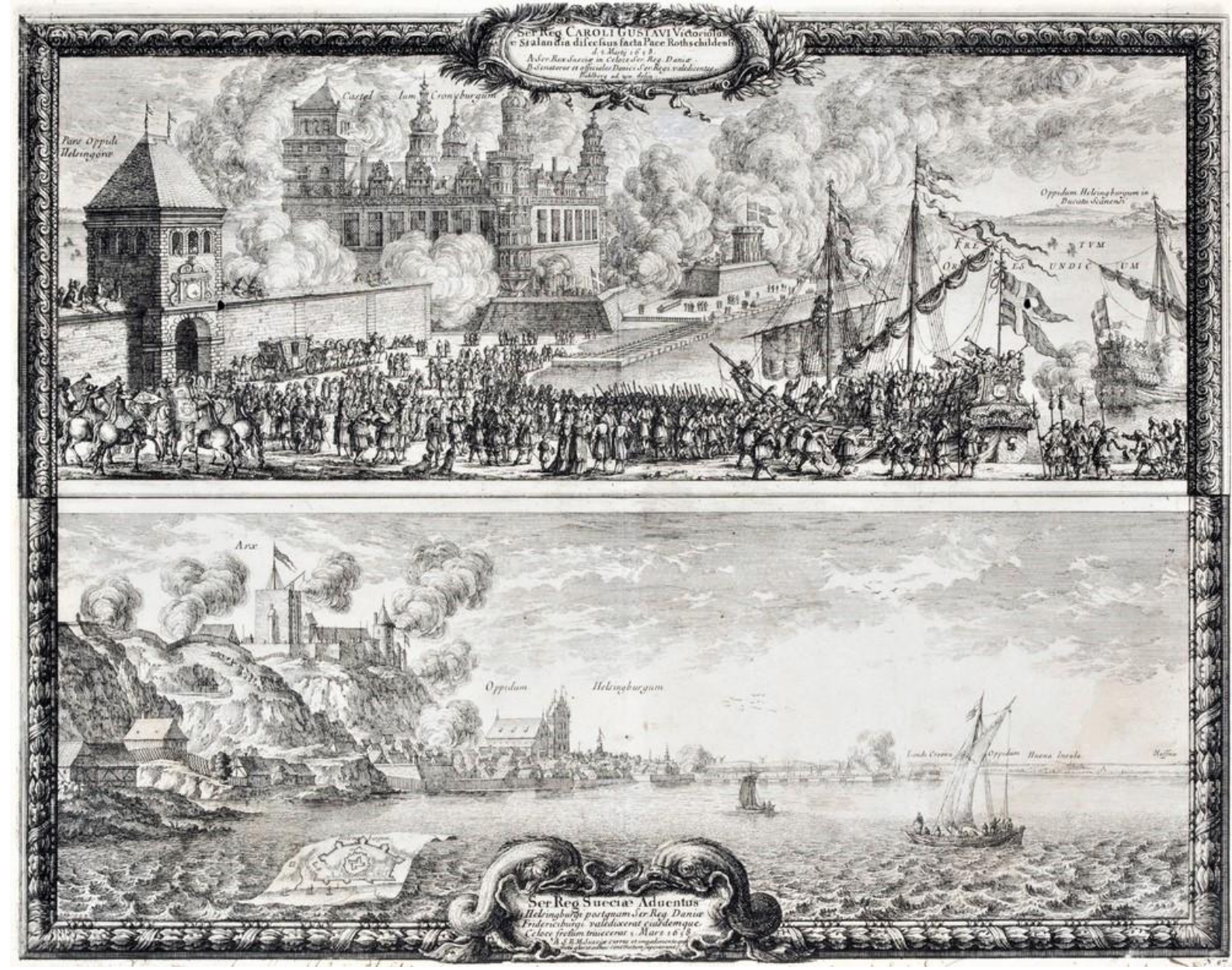

Figure 4: Dahlberg, E. 1696. Karl X Gustav's takeover of Scania 1658. Helsingborgs museum. 
A decision was made to demolish one quarter of the town's blocks to make space for the fortifications at the southern and northern entrances to the town as well as along the shoreline. It was determined that 108 plots were affected by the fortifications, of which 62 contained buildings and the rest were vegetable gardens or empty land. The total value of the properties was estimated at 12,406 riksdalers and the cost of dismantling houses and rebuilding them in a new place was calculated at 5500 riksdalers. (Johannesson, 1969c, p. 226). It was decided to offer some of the Crown land near the castle to those who lost their gardens. Negotiations with property owners about reimbursement took so long that the länsman Ove Giedde had to order houses demolished or moved in 1655 before any money had come in. As restitution, in 1655 Helsingborg was freed from all taxes to the Crown for 12 years. Unfortunately, the residents of Helsingborg were never fully recompensed by the Danish Crown because the Treaty of Roskilde at the end of the 1657-1658 war ceded Scania to Sweden. On March 1, 1658, as the result of the Treaty of Roskilde, Helsingborg was handed over to Sweden. The Swedish King Karl X Gustav visited the Danish King Frederik III at the Kronborg Castle on March 5, then took his ship across to Helsingborg (Figure 4). He was met by the Lund bishop, the new commandant of the castle, and the two mayors, Jens Nielsen and Eggert Elers with five aldermen. The King stayed for two days at the house of Elers on Storgatan (Figure 5) (Åberg, 1969, p. 14).

Despite the peace treaty, a new war broke out later the same year. Over the next year the town was filled with various military personnel, including German and Polish troops. There was a shortage of lodging. Thefts, conflicts and fights with officers and their wives were typical of this period. Officers bought goods on credit and never paid. In 1660, the residents of Helsingborg petitioned the Crown to say that the town was badly affected by quartering of the troops, repairs, big warships passing by, and countless shootings. Even more burghers lost their properties due to the expansion of the fortifications. The defense from the Öresund side was still poor.

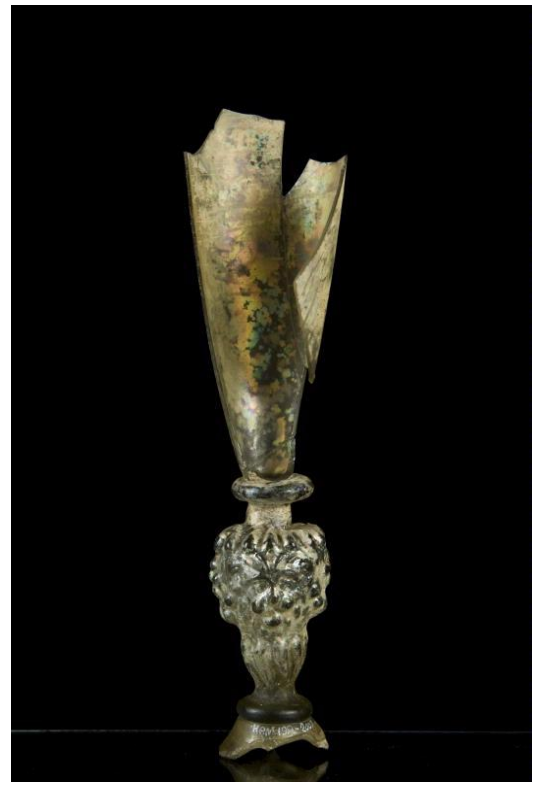

Figure 5: Venetian wine glass found at Eggert Elers house on Storgatan (199-2002). Helsingborgs museum.

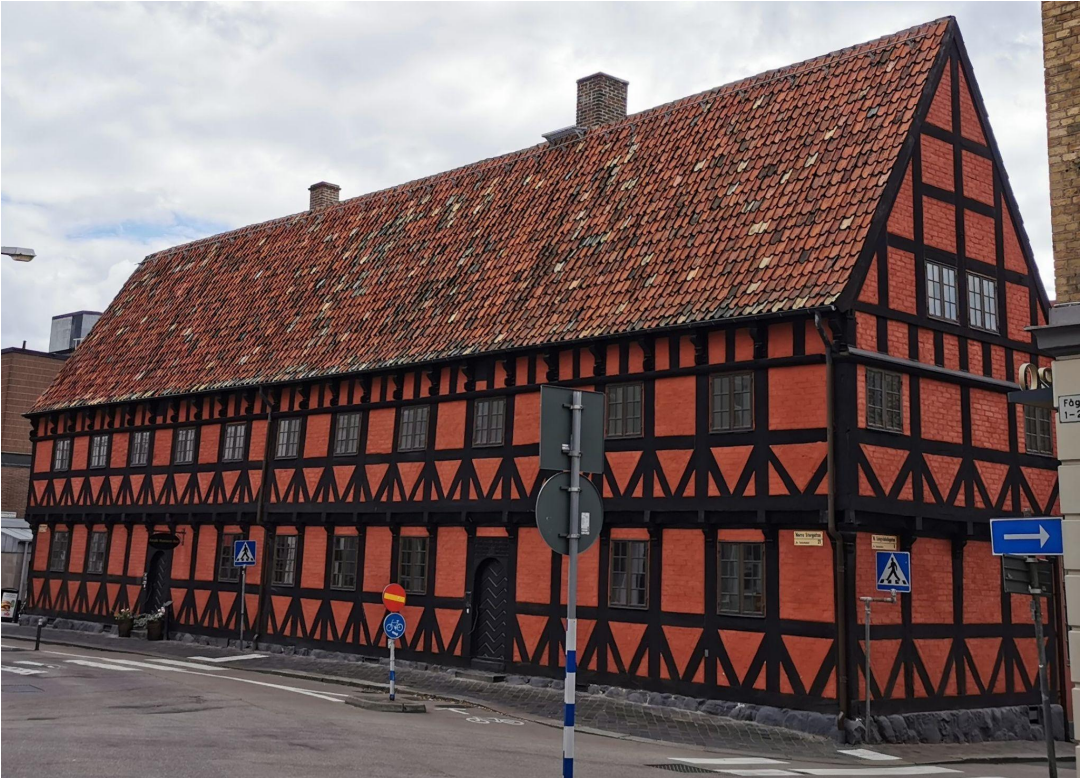

Figure 6: Jacob Hansen's house on Norra Storgatan. Hansen and his spouse Inger Mogensdotter built the house in 1641 . Hansen was a merchant, bailiff and alderman. 
The shore was guarded by patrols, especially in winter when the Öresund froze over and people could cross over on foot. Suspected interlopers were arrested and brought to the castle for questioning (Åberg, 1969, p. 24)

The Scanian war of $1676-1679$ is a topic that has been broadly discussed elsewhere, therefore I will only briefly mention the events that directly affected the lives of Helsingborg residents. In September 1675, Denmark declared war on Sweden. Young peasants and servants from Helsingborg area fled to Denmark to avoid being conscripted in the Swedish army. The situation at the Helsingborg garrison was demoralising - pay was delayed and provisions delivered by peasants were insufficient. In January 1676, of the 346 men in the garrison at the castle, 102 were sick and 25 had died. On June 30, Danes marched on Helsingborg and launched an artillery assault. A cannonball hit the well at the castle and the garrison lost their supply of fresh water, which lowered the already poor morale. On July 4, the commandant Hästesko capitulated. In December 1676, Swedes took Helsingborg back, while Landskrona remained under Danish control. The majority of burghers by then had fled the town and their houses were plundered of anything of value. At least 82 burghers from Helsingborg were listed as traitors for fleeing to Denmark and issued court summons. Some who attempted to return to town were arrested on arrival. On the night of April 5, 1677, four Danish battalions entered the town from the south; they were answered by heavy cannon fire from the castle, and the battle left many dead around the St. Maria churchyard and on the streets (Åberg, 1969, p. 63). Helsingborg remained in Swedish hands until 1678.

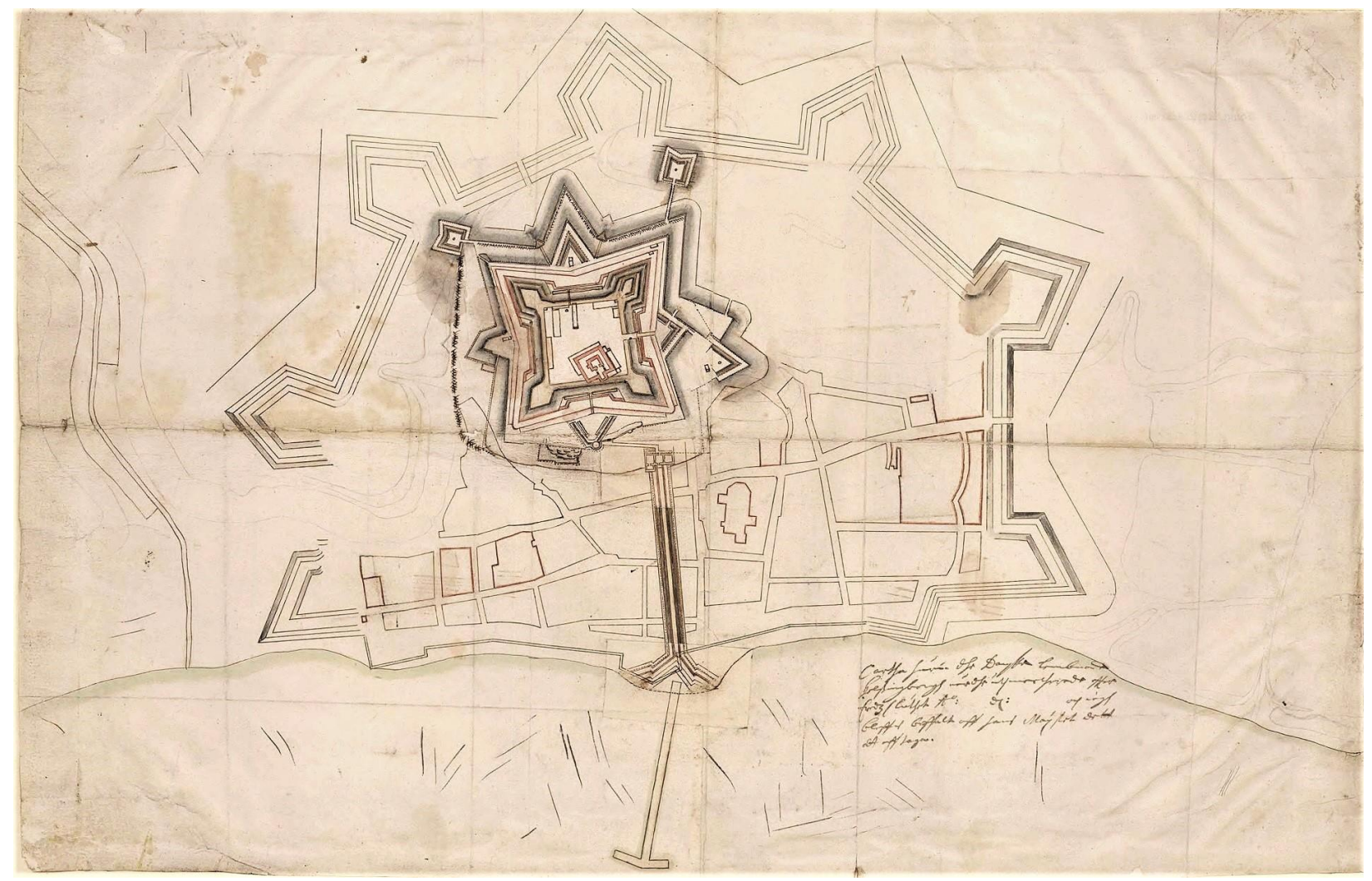

Figure 7: Erik Dahlberg's map of Helsingborg in 1679, showing the communication line and fortifications. The buildings marked in red were left standing after the demolition. Lantmäteriets historiska kartarkiv. 
When the Swedish garrison capitulated again, the Danes continued to expand the fortifications, for which they brought in soldiers from the Landskrona garrison as well as 400 peasants from Zealand. In spring 1679 it was decided that in order to receive reinforcements from the Öresund, a fortified communication line from the castle to the ship pier had to be created (Figure 7) (Mårtensson, 1969c, p. 212). An order came to demolish all houses in the way of this line so that Swedes could not use them as cover. A list was drawn up with 33 properties in the northern half of the town and 27 to the south of the church, including the town hall and the priest's residence. The remaining buildings were to be used for storage of munitions and housing the troops. The burghers were dismayed but their pleas to spare their properties went unheard. In March, the order to demolish 70 buildings was put to action. Many of the residents got only two hours' notice to leave everything behind and evacuate to Landskrona; others left for Helsingör. What houses were not immediately torn down were burnt and ruined during the later stages of the war (Johannesson, 1969d, p. 70).

The war ended with the Lund peace treaty on September 26, 1679 in Swedish favour. The Danish garrison had to leave Helsingborg. In summer 1679, the Danish government had offered all residents of the demolished Helsingborg the option to settle in Danish towns and receive a twenty-year reprieve from all taxes. By 1680, 51 burghers from Helsingborg had accepted the offer (Åberg, 1969, p. 76). The poor of Helsingborg were also offered help to resettle in Helsingör. In April 1680, nineteen burghers presented themselves to the Helsingborg magistrate to swear fealty to the Swedish King Karl XI, among them four former aldermen, but also several craftsmen and two ferrymen.

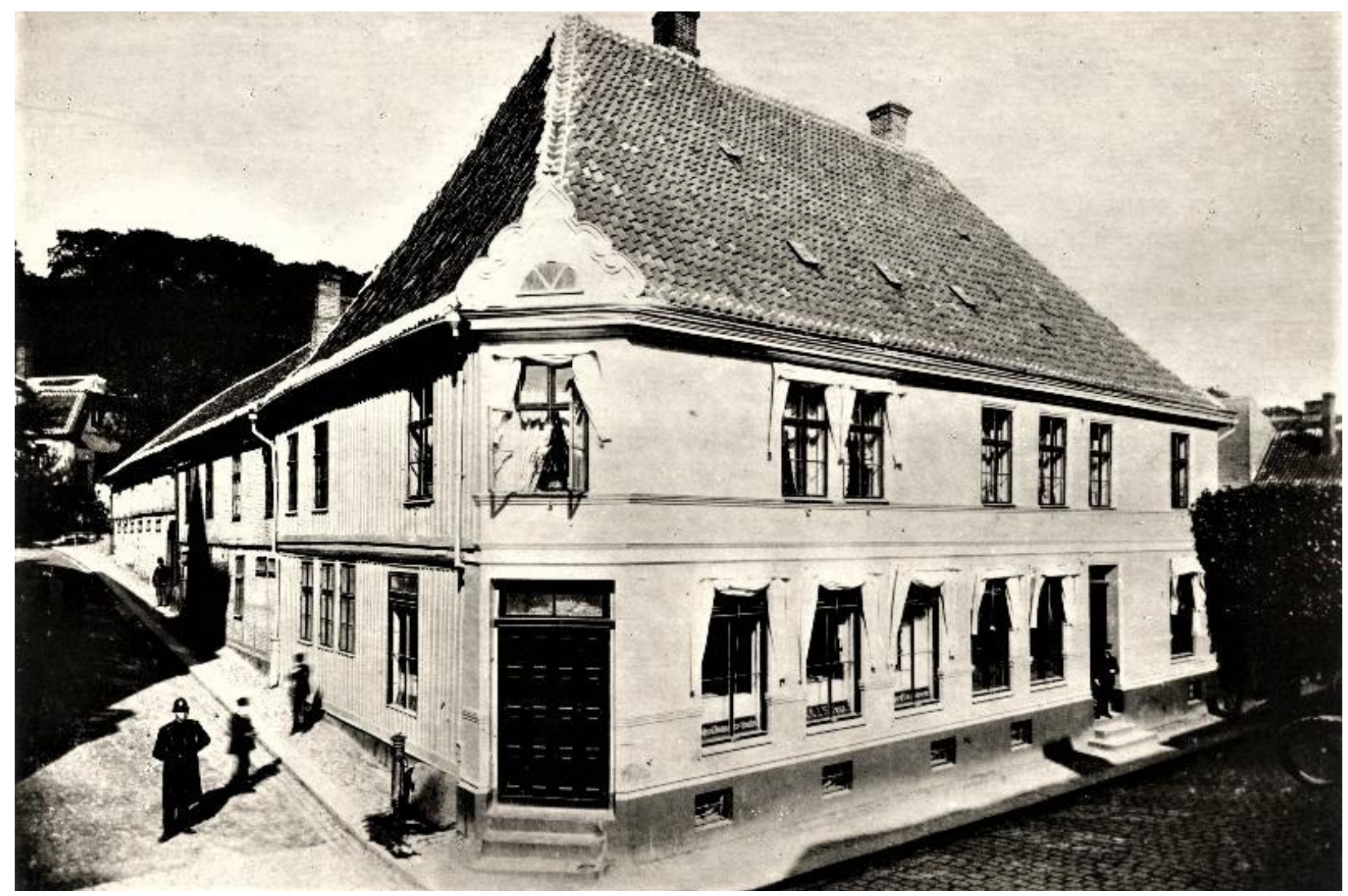

Figure 8: the main building of Henckelska gården on Norra Storgatan, built in 1681. 1880s. Helsingborgs museum. 


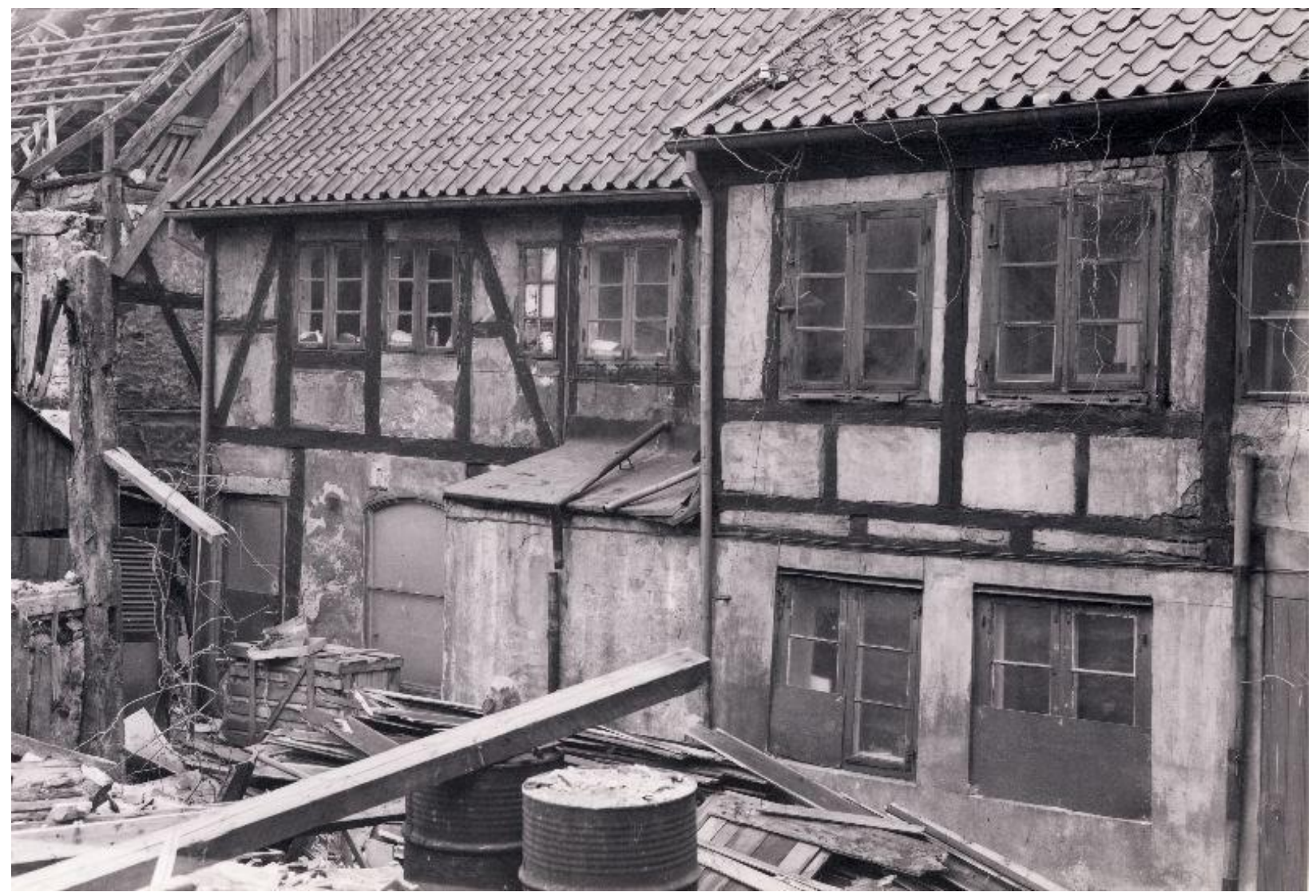

Figure 9: Bendt Pihl's house from the late 1600s on Kullagatan 18 was demolished in 1963. Bendt Pihl was a merchant and one of the main importers of tobacco. Helsingborgs museum.

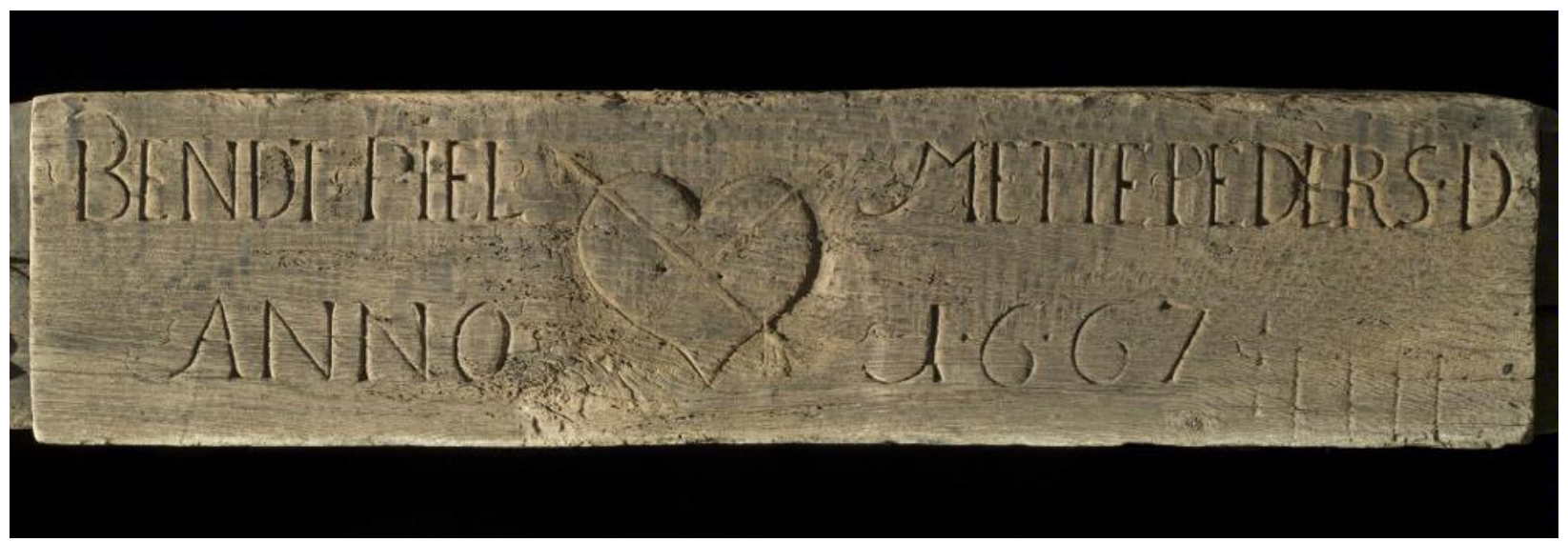

Figure 10: a detail from Bendt Pihl's house. Helsingborgs museum.

The Scanian governor general Rutger von Ascheberg visited Helsingborg two years after the end of the war and described in a letter to the King that the town had been ransacked repeatedly, houses torn down and burned out. "The town is populated mostly by miserable people who for the most part still live in basements of burnt houses. With the exception of six people, there is nobody in town who doesn't owe twice as much in debt as he owns." (Åberg, 1969, p. 78).

When Karl XI visited Helsingborg after the Danish troops had left it, he ordered all fortifications torn down, except for the castle tower (Mårtensson, 1969c, p. 220). In May 1680, soldiers and 
peasants began to dismantle the outer fortifications; the soil from the earthworks was used to fill the moat. In 1682, another 300 peasants were ordered to Helsingborg to finish tearing down the walls. Not only did most of the dwellings in the town have to be rebuilt, the town council had also lost its properties; the school and the hospital as well as the town hall by the church had been torn down. In the next few years the town hall met in rented buildings, including Herman Schlyter's newly built property, the current Henckelska gården on Norra Storgatan (Figure 8).

The estimated population of Helsingborg in the 1690s was 900-1000 (Johannesson, 1969e, p. 248). Along with returning residents, the population growth was helped by immigration, including foreigners from Germany, the Netherlands, Scotland, and Norway. There were not many new Swedish-born residents, despite government efforts to place Swedish persons in crucial positions such as school teachers, priests, and tax collectors.

The common market with Helsingör was no longer operational as it was now a foreign town. Passage across to Denmark now required a passport issued by the magistrate of Helsingborg. All goods transported into town were subject to taxation. A 1693 order stated that residents of Helsingborg are allowed to bring goods with them across the Sound only three days a week, Monday, Wednesday and Saturday (Fagerlund, 2003). There were complaints about a shortage of goods brought by sea and smuggling was commonplace, including tobacco. Two of the main Scanian exports to Denmark, cattle and horses, were no longer profitable and instead were directed to Ystad and from there transported to Germany.

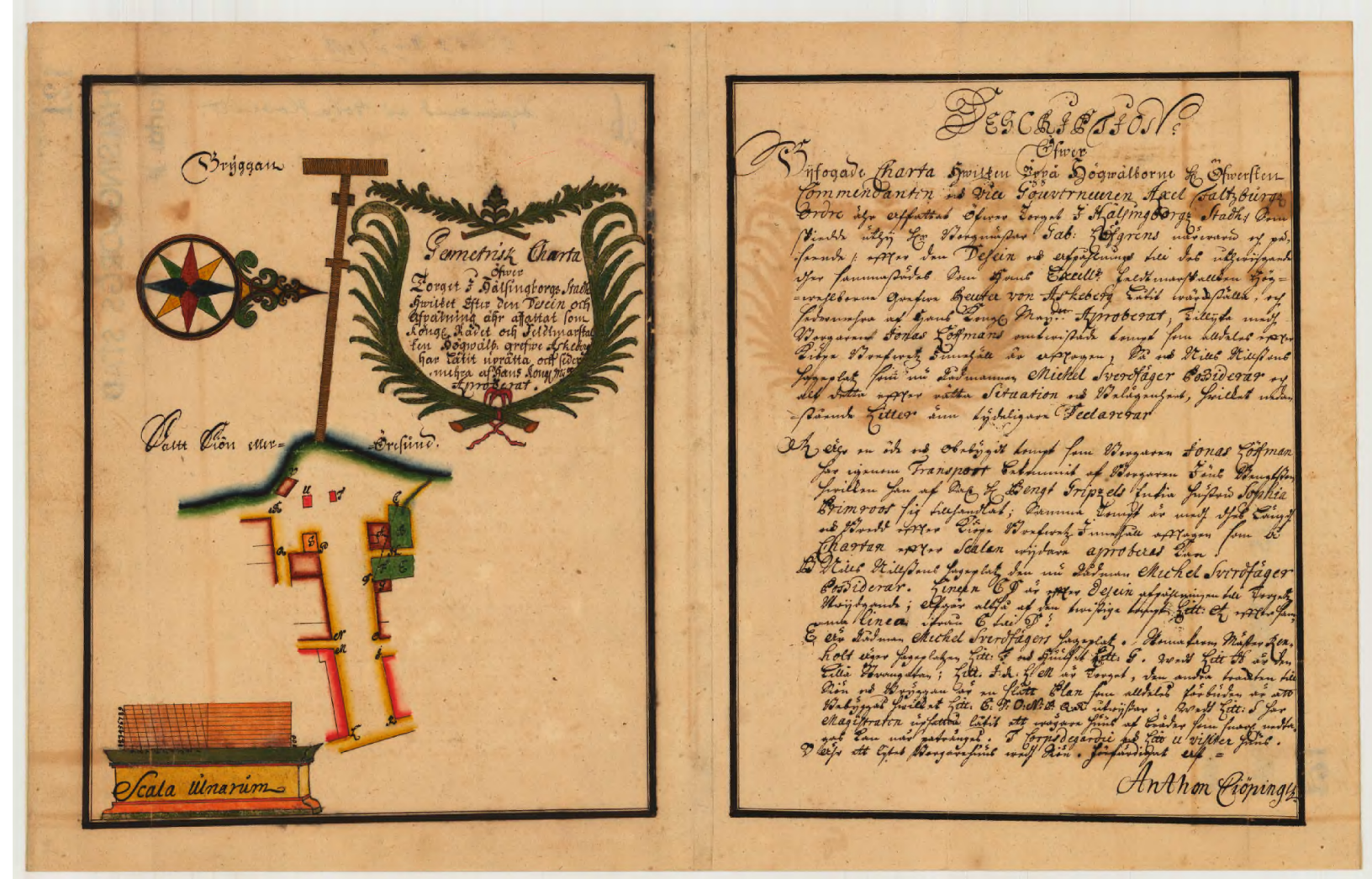

Figure 11: a map of Stortorget in 1706, listing buildings, streets, and property owner names. Lantmäteriets historiska kartarkiv. 
Only a small number of craftsmen worked in Helsingborg in the early 1680s: a goldsmith, a glovemaker, a hatmaker, a saddler, two tanners, and two belt makers. The town had a barber-surgeon, an apothecary, a gardener, and two musicians hired to play at the church (Johannesson, 1969d, p. 42). Most of the blocks in the demolished neighbourhoods were built up again, except for Stortorget, which was created in 1692 as the new market square (Figure 11).

Beginning in 1658 there were attempts to convince the merchants to use Swedish weights and measurements but the feedback was mostly negative until 1687 when the governor general issued a new order requiring the use of the Swedish system. Both Swedish and Danish coins were used during the 1660-1670s, as evidenced by buried coin hoards found in town (Jonsson, 2018). With the formal incorporation of Scania into Sweden in the 1680 s, the efforts towards "swedishisation" increased. The new policies can be particularly attributed to the governor general Rutger von Ascheberg who himself was a Baltic German and an immigrant to Sweden (Gustaffson, 2003). The attempts to turn Scanians Swedish continued to meet resistance for decades to come.

Denmark made their last push to take back Scania by landing 15,000 troops at Råå, south of Helsingborg, in November 1709 and entering Helsingborg which was no longer protected by fortifications. It was no surprise that the town magistrate along with more than 100 other burghers pledged allegiance to the Danish king. A new line of earthworks was built to the east of Kärnan. In the final battle between Denmark and Sweden in March 1710, the Danish army took massive losses and retreated to Helsingborg, which was then bombarded by the Swedish army. The Danish army was forced to leave Scania but only after slaughtering all their horses in the streets of Helsingborg. Horse cadavers with full equipment on them, including weapon holsters, saddle bags, muskets and pistols, were buried in pits outside the town gates and in the fortification moats. The work to clean the town took several weeks (Åberg, 1969, p. 103). One such pit with horse skeletons was excavated in the Kärnan Norra block south of Långvinkelsgatan in 1938. A similar discovery was made in 1944 in the Kullen Östra block on the northern side of Långvinkelsgatan (Mårtensson, 1969a). 488 finds from the 1710 battle, the majority of them horse equipment as well as munition and weapons, are held in Helsingborg's Kulturmagasinet.

In the following year, a plague started in Stockholm and by spring 1711 it had arrived in Helsingborg. Attempts by the authorities to limit the spread of the disease were resisted by the population throughout Sweden. Ignoring the restrictions, they visited the sick, reused personal belongings of the dead and dug up the buried bodies to rebury them in churchyards (Arcini, Jacobsson and Persson, 2006). The location of a mass grave from the 1711 plague has been identified in Helsingborg at Slottshagen. The plague continued to ravage Scania until spring 1712. After the war and the plague, the population of Helsingborg in 1720 was only around 700. For the entire 18th century Helsingborg remained a small and slowly growing town. Only in the 1800s did the population numbers reach the pre-Scanian war levels (Johannesson, 1979, p. 118). 


\section{Brief overview of urban archaeology in Helsingborg}

Archaeology in Helsingborg began around the time of the foundation of the Helsingborg museum in 1909. Beginning in the late 1800s, occasional finds from the town were gifted to the National Historical Museum in Stockholm. Consul Oscar Trapp was involved in the restoration of Kärnan and had an interest in history. His private archaeological collection was one of the first major exhibits at the museum. Trapp and the assistant director of the museum, Lindblom, investigated the remains of St. Petri church at Vattentornet block in 1910. The first organised archaeological excavation took place in 1911; its target was a waste heap from the Pålsjö faience factory from the 1760s. Torsten Mårtensson worked as the director of the museum from 1913 to 1955 and during these decades led many archaeological excavations in town (Ohlsson, 2009). Among them were excavations around Kärnan in 1925 and 1930-1933, at Billeplatsen in 1914 and 1939-1940, the first excavation at St. Nicolai dominican monastery in 1938, and digs in connection with demolishing older buildings in the town centre and new constructions.

In the next few decades, the two big names in Helsingborg archaeology were Lars-Göran Kindström and Margareta Weidhagen-Hallerdt. Kindström was the director of the museum as well as the city antiquarian until 1987. They were involved in major archaeological excavations at St. Clemens church, St. Nicolai monastery, Billeplatsen, St. Maria church and Tor block. Initially, finds from excavations in Helsingborg were stored in Helsingborg's museum or the National Historical Museum in Stockholm, but from 1965 on they have been sent to the Lund University Historical Museum. Starting in the 1970s, archaeological investigations in Helsingborg have been carried out by the Swedish National Heritage Board UV-Syd in Lund.

According to Wihlborg (1981, p. 23), by the beginning of the 1980s, 97 archaeological observations and excavations had been registered in Helsingborg. During the 1980s, several archaeological projects took place in the residential blocks of Kärnan Mellersta, Tor, Karl XI Norra, Ruuth, Thalia, Norden, and the 1982 and 1990 excavations of the St. Olof church and graveyard. The last two decades of Helsingborg archaeology are characterised by commercial archaeology in connection with street and utility improvement projects, among them excavations in Minerva block, Slottshagen, Lasarettet block and various other locations in the old town (Bolander and Larsson, 2017). 


\section{Material}

\section{Post-medieval ceramics}

According to Carlsson and Rosén (2002), around the year 1500 northern Europe experienced a "ceramic revolution", a major change in the use of ceramic vessels in households. Historically, the ceramic transition happens shortly before the Reformation, which is one of the temporal markers in northern Europe used to separate the medieval and post-medieval periods. In the Kingdom of Denmark which then included parts of modern day Sweden, the Reformation meant transfer of the Catholic Church property to the Crown in 1536-37, followed by closure and destruction of churches and monasteries (Wihlborg, 1981). The Reformation also brought the Renaissance style to home furnishings, coinciding with urbanisation and families no longer living in medieval one-room buildings (Thomasson, 1997). A distinction was made between peasant and burgher goods, with each class purchasing what was appropriate for its social status, according to the newly introduced Lutheran principles of social hierarchy.

Early modern Scandinavian society was hierarchical, based on the religious principle of a patriarchal household as a model for society (Tagesson, 2018). The personal belongings of an individual were expected to reflect their place on the social ladder, never exceeding it. In the 1700 s, though, the class system became less relevant and one's position was based more on merit since the feudal relationships were loosened and anyone with enough money could become a landowner. While the medieval peasants did not significantly differ in their consumption from the urban middle class (Poulsen, 2004), Rosén (2004) claims that in the 1600-1700s there was, in fact, a major difference between the material culture of the city and the country in southwestern Sweden, to the point of artisans crafting and merchants stocking two separate styles of inventories for the town and rural populations. Imported stoneware, faience and porcelain were all prestige goods, found in the city but rarely in the country. This rule is, however, not clear cut. While imported goods were indeed found more in the city, they were present even in remote rural locations such as Forest Finn farms at Grannäs and Svartviken, including German mineral water bottles and Westerwald stoneware (Elfwendahl, 2018).

Analyses of household consumption patterns disproportionately rely on ceramics since it is the most likely type of find to be preserved and present in literally every household. Even if soapstone, wood, metal, and glass vessels are found within the same assemblage, they are separated from the ceramic finds and often not analysed in the same context. Probate inventories starting from the mid-1600s are a good source of data for which items were actually used in a household, including objects such as candlesticks, utensils, table cloths and furniture. There is a notable discrepancy between what is listed in the probate inventories and what is found during excavations of the same site. Especially prior to the mid-1700s, inventories do not list redware ceramics, which is the most common archaeological find. Instead they list wood, tin and brass vessels which are not commonly found during an excavation. Wood and fabric as organic materials require waterlogged or otherwise anaerobic environmental conditions to be preserved over centuries, while soft metal objects such as plates, buttons and belt buckles were usually melted down and recycled into more fashionable styles. Older probate inventories are more likely to mention only a few exclusive ceramic items such as imported stoneware and faience but not kitchenware which was of low monetary value. Stoneware jugs with metal lids were listed among metal items since the value of metal was higher than that of ceramics (Rosén, 2004). Thus, a study of differences in social status based solely on archaeological finds will not give a full picture, being biased towards common ceramics. 
The analysis of post-medieval artefact assemblages cannot be fully separated from late medieval. As evidenced by urban excavations in southern Scandinavia (Augustsson, 1985; Carlsson and Rosén, 2002; Rosén, 2004; Linaa, 2016) and my personal experience with archaeological finds at the Helsingborg Museum, late medieval artefacts such as Siegburg stoneware and medieval redware from the 1300-1400s are often found on the same sites as ceramic stove tiles from the 1500s and post-medieval redware from the 1600s. Instead of artificially dividing the finds into medieval and post-medieval, they need to be analysed with relevance to the local history timeline. This method has been used by Augustsson (1985) in Halmstad by looking at the cross-era period between the move of the town to its current location in 1322 and its destruction in a fire in 1619; by Carlsson and Rosén (2002) in the towns of western Sweden, reflecting the period of redware use in households from the 1400s to the 1700s; and by Linaa (2016) who has looked at changes in urban consumption in Aarhus as an ongoing process between the Viking Age and 1800.

While certain artefact types have a specific terminus post quem such as tobacco pipes, other ceramic vessels may have a much longer lifespan. Rosén (2004) gives an example from Uddevalla where stoneware jugs were routinely found to be several decades older than tobacco pipes in the same context. Smoking pipes are the objects most likely closest to their time of production before being discarded, often a single-use item, bought already prefilled with tobacco. Cheaper and more common objects are more likely to be discarded sooner examples from England show that large amounts of household pottery and glassware were sometimes thrown out and smashed when moving to a new house (Johnson, 1996). Meanwhile, an expensive family heirloom is likely to be kept in the household for generations and repaired if damaged, skewing the relative dating of the assemblage.

Other than tobacco pipes, there are various changes in post-medieval material culture that assist with relative dating of archaeological finds. Occasionally, artefact styles are intentionally misleading. For example, it was fashionable for Raeren stoneware masters in the late 1500s to use pre-1500 woodcut patterns such as biblical scenes for stoneware designs (Gaimster, 1997). Outside of these exceptions, overarching trends such as the previously mentioned "ceramic revolution" give a good indication of the relative date of an assemblage. Starting in the 1400s, the older redware pottery - characterised by wheel-thrown, red-fired, either partly or fully oxidised clay, with usually yellow or orangeish lead glaze on the outside - was gradually replaced with younger redware. Its fabric is also red-fired but fully oxidised and of noticeably higher quality, and the inside of the vessel is completely lead-glazed, with the colours of the glaze ranging between dark brown and yellow or green. By the early 1500 s, the majority of ceramic finds are younger redware.

A greater variety of vessel forms and sizes was also introduced in the 1500 s, due to changes in social and eating habits. Whereas previously pottery was limited to the private sphere, namely kitchen and cooking, and tableware consisted of wood, soapstone, and metal objects, with pottery being represented almost only in the form of serving jugs, the growing urbanisation and social life brought ceramic plates, bowls and cups to the dining table. 


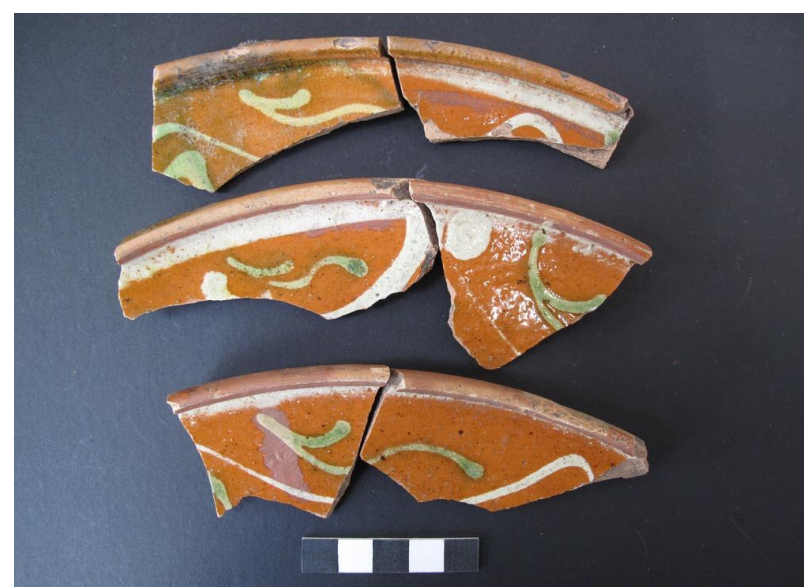

Figure 12: Werra ware plate, Germany, 1500--1600s.

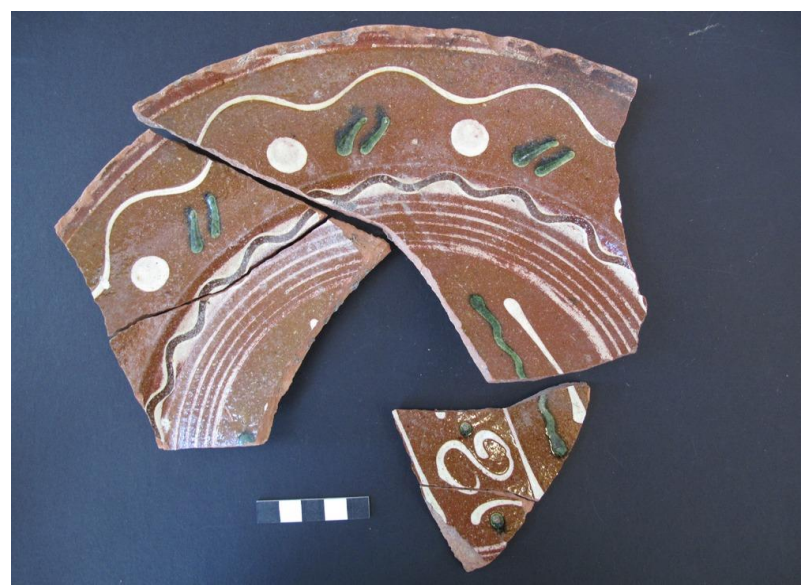

Figure 13: locally made slipware plate, with year $18 ? ?$ on one sherd dating it to the 1800s.

Decorated ceramic plates appeared in urban households, first as northern German imports such as Werra and Weser ware, and later as locally made ceramics, made to copy the imported patterns such as concentric waved bands. Weser and Werra ware were produced in Lower Saxony from the 1500s until the mid-1600s (Demuth, 2015). Internally glazed redware tripod pipkins of smaller sizes were used as cookware and in urban households their shapes now included shallow frying pans, indicating that families of higher social status had started including various fried foods in their diet, served on individual plates, as opposed to the entire household eating stews and porridges from a large common cooking pot (Rosén, 2004; Linaa, 2016).

The move to separate rooms in urban dwellings not only furthered the separation of kitchen and dining, it also brought the need to heat them more efficiently. In all probability the need for better heating was increased by the cooler climate in northern Europe with the ending of the Medieval Warm Period. A type of ceramic object characteristic of the 1500s and 1600s is a black or green glazed, decorated tile used to cover ceramic stoves (Tagesson and Jeppsson, 2015). Glazed stove tiles are a frequent find from post-medieval sites in Helsingborg.

Global developments such as overseas trade and colonialism and the Thirty Years' War in Europe (1618-48) increased migration of merchants and craftsmen and interest in foreign cultures and ideas. The presence of European traders of mixed ancestry in all major Scandinavian ports had an effect on the movement of goods and networking across ethnic boundaries (Dalhede, 2018; Nordin, 2020).

Asian trade goods had been making their way to Scandinavia through indirect trade in smaller quantities before the 1700s but imported porcelain was found only in upper class homes. The earliest documentary evidence of Chinese porcelain in Scandinavia is in Helsingör probate inventories of merchant houses dating to the late 1500s (Kristensen, 2014). Meanwhile in Helsingborg, there are no porcelain finds until the 1700s. The earliest probate inventories were destroyed when the town archives burned down along with the town hall during the war of 1676-79. It is possible that Chinese porcelain did not reach Helsingborg until the Swedish East India Company was founded and began imports to Gothenburg in 1731. 


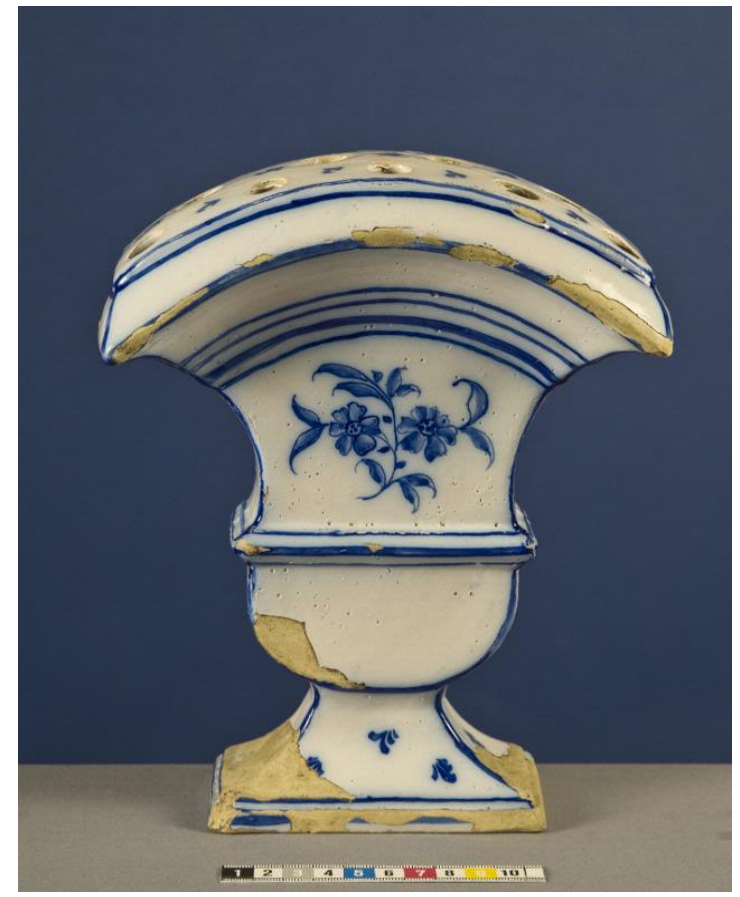

Figure 14: a tulip vase made at Pålsjö faience factory in Helsingborg, 1772-1774. Helsingborgs museum.

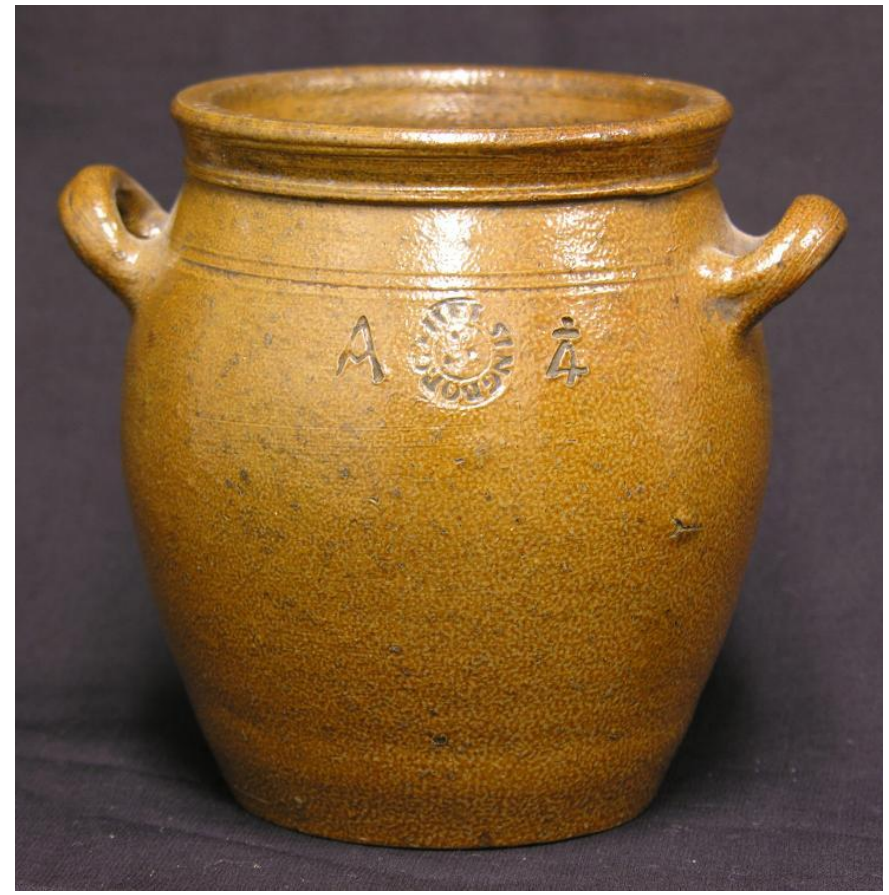

Figure 15: a stoneware jar made at Ruuthska bruket in Helsingborg, 1799-1841. Helsingborgs museum.

In the 1730s, a porcelain tea service and tea drinking became fashionable indicators of one's social standing. The introduction of coffee had a similar effect on social customs and ceramic vessel types. Ceramics were more likely to come as sets, recorded in probate inventories as a dozen or half a dozen, particularly when referring to tea cups. New vessel types such as soup terrines and punch bowls were introduced. Because mass-produced Chinese porcelain arrived in Sweden via Gothenburg, it became more common and affordable in western and southern Sweden and was no longer restricted to upper classes. Porcelain sets with family coats of arms or monograms were individually ordered from China by burghers who wanted to demonstrate their privilege (Linder, 2015).

Also in the 1700s, the production of faience began in Sweden. Rörstrand faience factory was founded near Stockholm in 1725. Pålsjö faience factory near Helsingborg was the first in southern Sweden, founded in 1765. In 1798, the first industrial factory, Ruuthska bruket, opened in Helsingborg, producing salt-glazed stoneware household vessels. Northwestern Scania around Helsingborg and Höganäs is one of the few places in the country with clays suitable for industrial stoneware production (Lindquist, 2015). A transition to factory-produced ceramics signifies the end of the post-medieval era. Carlsson and Rosén (2002) similarly suggest the year 1800 , when industrially produced creamware began to replace redware in everyday use, as the end point of post-medieval material culture and the beginning of modern or industrial archaeology. 


\section{Case studies of sites}

\section{Overview}

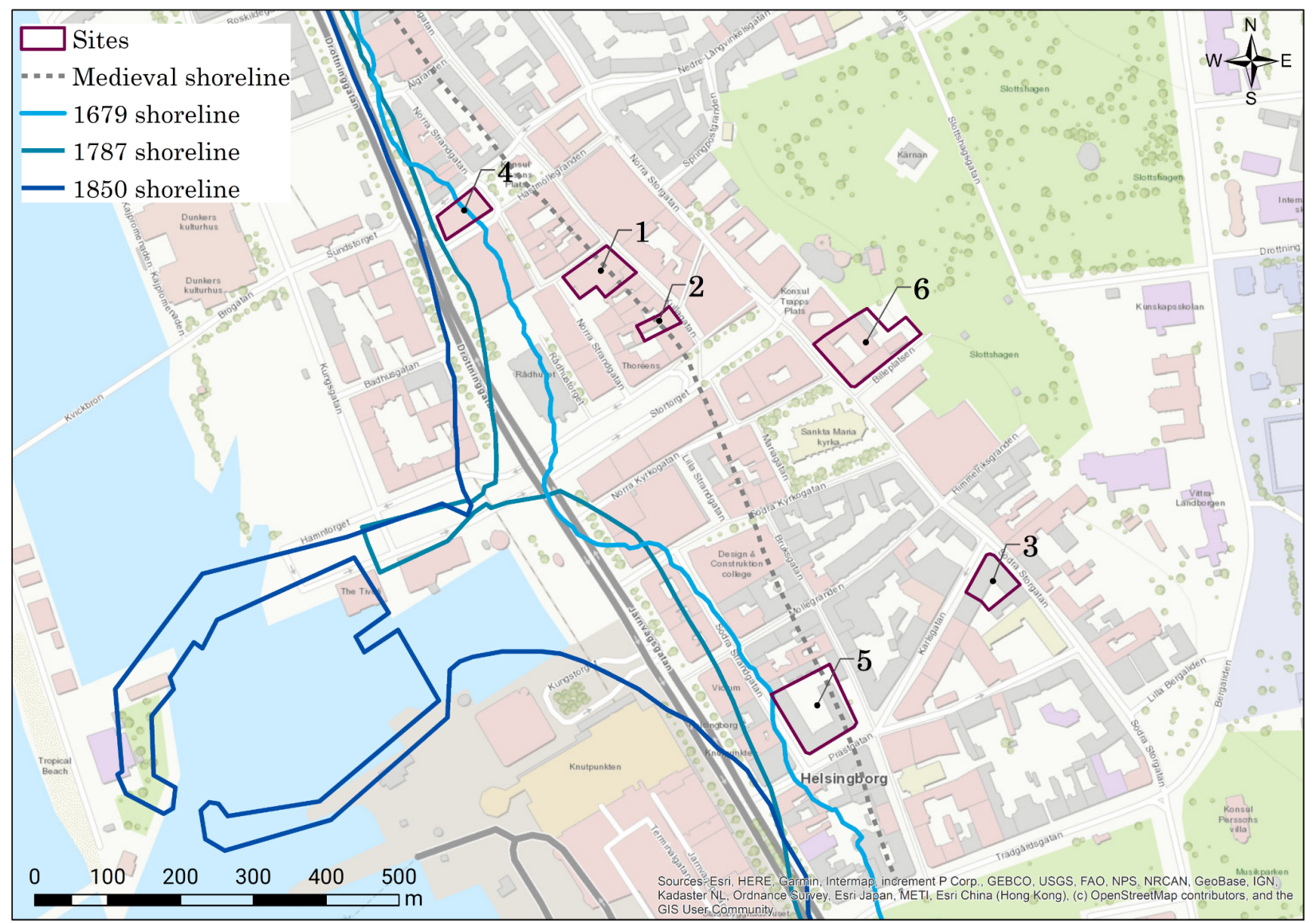

Figure 16: locations of the selected sites in Helsingborg and changes to the shoreline over centuries. 1. Norden 24, 2. Norden 19, 3. Karl XI Södra 20, 4. Färjan 4, 5. Thalia 8, 6. Kärnan Mellersta 9.

Six sites in the lower town of Helsingborg were chosen for this study (Figure 16). The criteria for my choice of sites for the case studies were their location, time period of occupation and availability of complete finds lists. The seventh site, Erik Dahlberg 1, was initially considered for inclusion in this study but registration of the finds could not be completed on time due to the covid-19 pandemic restrictions in 2020-2021. Several other sites in the study area have sufficient archaeological material but it has not yet been processed and registered.

Three of the sites, Norden 19, Karl XI Södra 20 and Färjan 4, were excavated in the late 1920s and the beginning of the 1930s as part of construction work in town. Another three sites, Norden 24, Thalia 8 and Kärnan Mellersta 9, were investigated between 1984 and 1988 by UV-Syd. The 1920-1930s excavations are characterised by a lack of archaeological reports or drawings. Helsingborg museum's annual reports from this time cover excavations in town in one or two paragraphs, focusing on interesting sites and objects but not giving any detailed information on the rest of the finds or site stratigraphy. Excavation methods may have been limited to picking up loose finds without registering their context. The area of excavations at Karl XI Södra 20 and Färjan 4 is not known. The total area of Norden 19 is $404.5 \mathrm{~m}^{2}$ but it is not 
known whether the entire property was excavated. Kärnan Mellersta 9 was investigated in a 700 $\mathrm{m}^{2}$ area which includes standing buildings. Excavation trenches at Norden 24 and Thalia 8 were $320 \mathrm{~m}^{2}$ and $360 \mathrm{~m}^{2}$, respectively.

Artefacts from the urban excavations in Helsingborg prior to 1964 are mostly stored in Helsingborg's Kulturmagasinet, with some particularly noteworthy objects having been sent to the National Historical Museum in Stockholm, while bone material was kept at the former Lund University Zoological Museum. The Kulturmagasinet storage holds a large number of unregistered finds from these older excavations. Registration of these finds has been a part of my internship and volunteer work for the past year. Excavations from the 1980s have archaeological reports available in print at the Kulturmagasinet archives with digital copies available on request from the Swedish National Heritage Board. Finds from the excavations are held at the Lund University Historical Museum.

All of the sites were part of the early modern lower town; however their earliest dates vary from medieval to the late 1600s (Färjan 4). Four of the sites are located to the north of St. Maria church and two to the south. Four of the sites, Norden 24 and 19, Karl XI Södra 20, and Kärnan Mellersta 9, were part of the same destruction event in 1679 when the town was demolished during the Scanian war.

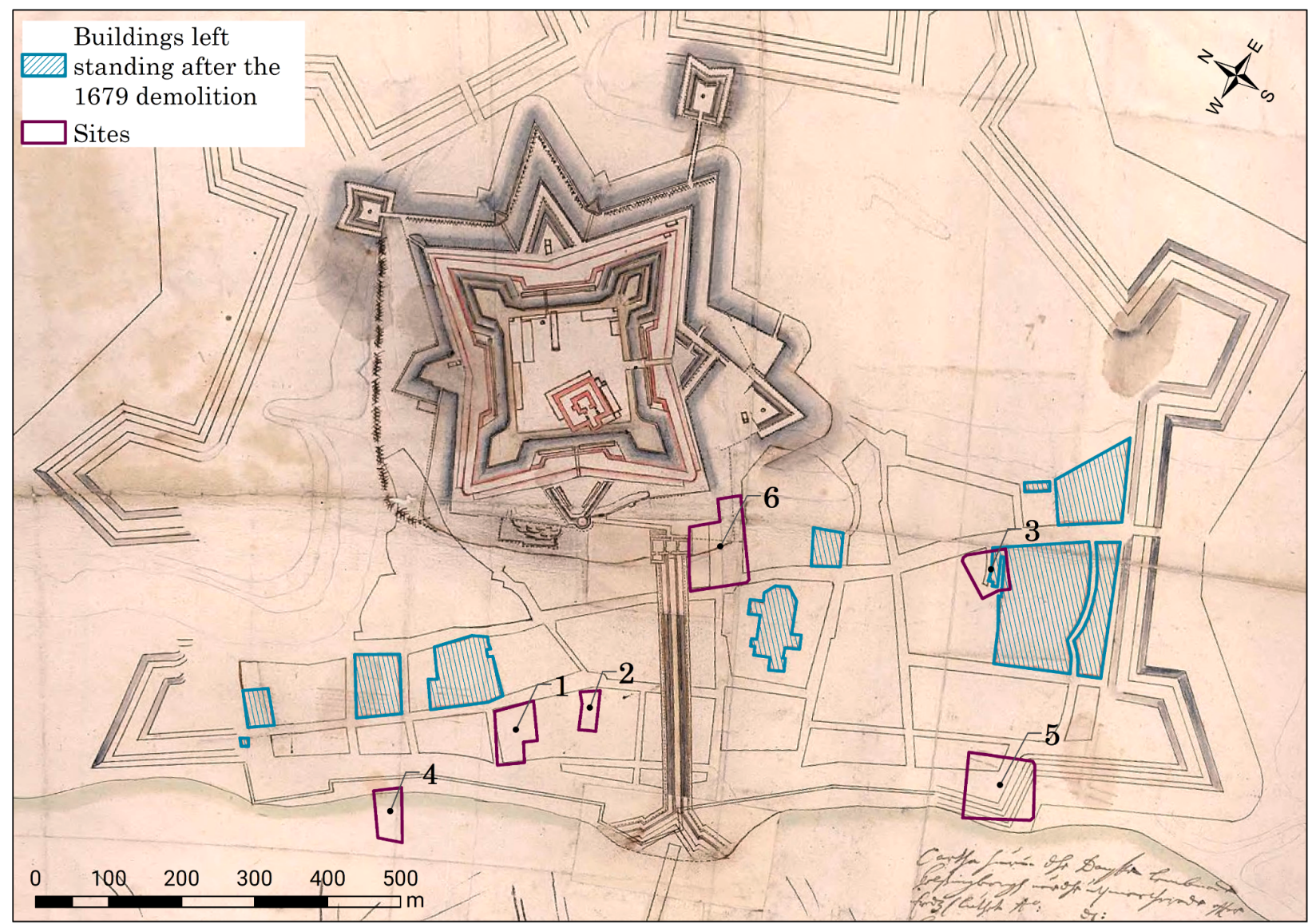

Figure 17: locations of the selected sites over a map of Helsingborg in 1679 by Erik Dahlberg, highlighting buildings that survived the March 1679 demolition. 1. Norden 24, 2. Norden 19, 3. Karl XI Södra 20, 4. Färjan 4, 5. Thalia 8, 6. Kärnan Mellersta 9. 
One site, Thalia 8 , had already been demolished earlier to make space for the town fortifications in the 1650s and one site, Färjan 4, was still either under the shore level or was partly covered by the shore fortification wall (Figure 17).

I have attempted to use a ceramic classification system inspired by the work of Jette Linaa on pottery from Aarhus (2016) and Helsingör and Aalborg (2020) to make a comparison of various sites possible. However, mainly due to the lack of identification data, certain shortcuts had to be taken and finds were grouped into fewer categories. For the sites at Norden 19, Karl XI Södra 20 and Färjan 4, all potential identification mistakes are my own and have occurred because of my relative inexperience with typology of pottery found in southern Sweden. For the sites at Norden 19, Thalia 8 and Kärnan Mellersta 9, the finds lists from the 1980s use Selling's typology system where, for example, all post-medieval redware is listed as type BII:4 regardless of its origin (Johansson and Århem, 2015). I have not been able to determine the ratio of imported versus local artefacts for these sites. Unfortunately, the finds list from Kärnan Mellersta 9 does not contain either a count of sherds or the weight of each listed object and cannot be directly compared with other sites.

Although commonly listed with redware in finds lists, I chose to exclude stove tiles from the ceramic totals. This is because when the sites were excavated in Helsingborg in the 1920-30s, some of the tiles were collected separately and stored without distinguishing which site they came from. Therefore, it is impossible to accurately assess the amount of tile material from each site.
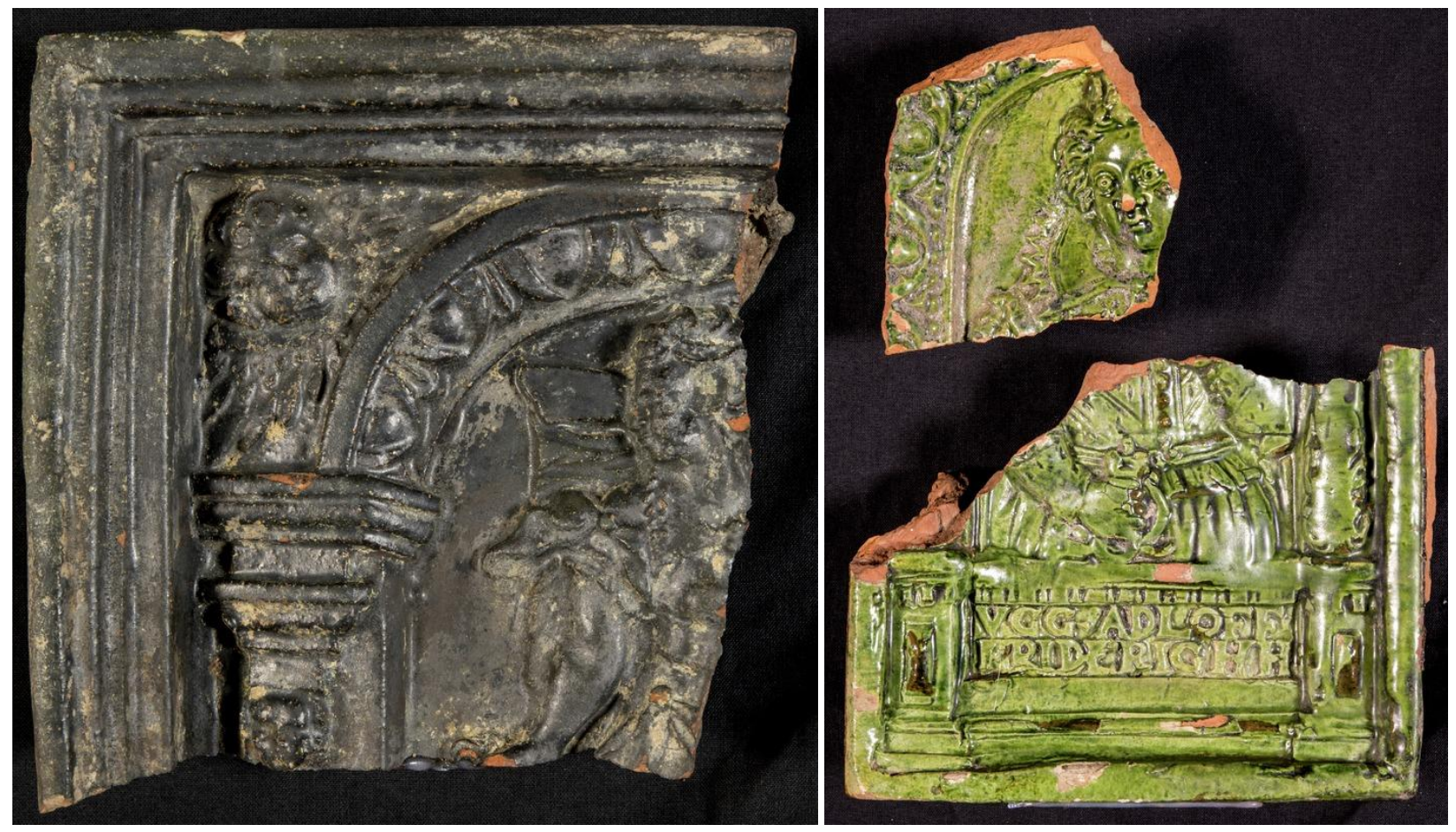

Figure 18: fragments of stove tiles excavated by Torsten Mårtensson in 1927 at either Fågelsångsgatan 23 or Kullagatan 3, 1500s (left) and early 1600s (right). Helsingborgs museum. 


\section{Norden 24}

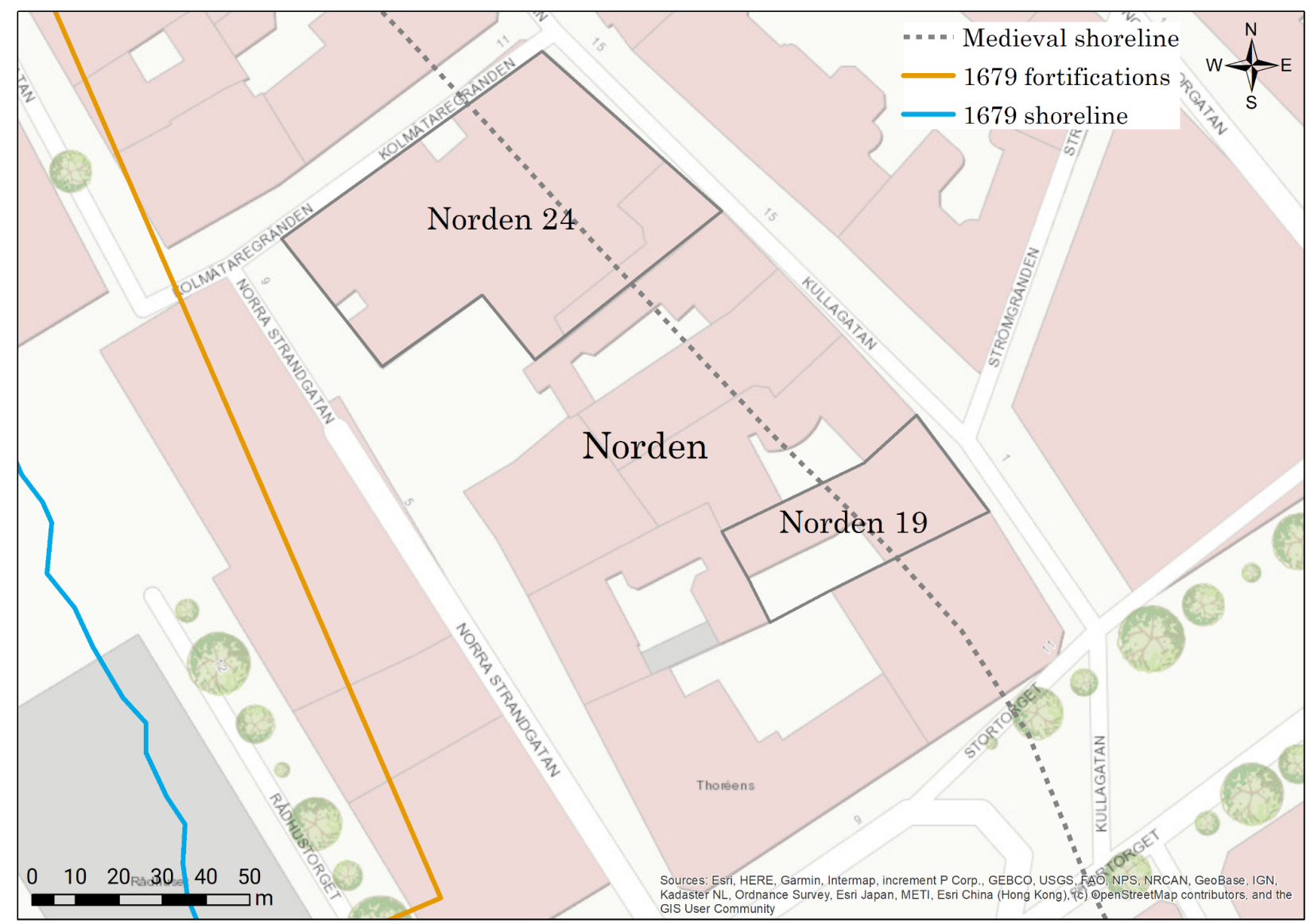

Figure 19: map of Norden block.

Block Norden 24 is located at the northern end of the city block, between Kullagatan to the east, Kolmätaregränden to the north, and Norra Strandgatan to the west. During the medieval period, the eastern side of Kullagatan was one of the earliest expansions into the lower town, after the area around St. Maria church. Beginning in the 1300s, Kullagatan - which ran parallel to the shoreline and Storgatan to the east - was one of the main streets of the city (Wihlborg, 1981). The medieval shoreline crossed the western half of the Norden block.

The modern day property Norden 24 comprises the former numbers 1, 2, 16 and 17. Two buildings at Kolmätaregränden 8 and Norra Storgatan 18 (former Norden 16/17) were built in 1814. The 1989 building in the location of former Norden 1 currently houses a Lindex store. The previous building was torn down in the 1980s. Due to a planned new construction, a preliminary excavation was conducted by UV-Syd in February 1988. Remains of buildings from the 1600s were found under a thick layer of rubble. An intensive excavation of a $320 \mathrm{~m}^{2}$ area directly south of the corner of Kullagatan and Kolmätaregränden followed in August - September 1988 (RA $\ddot{A}$ dnr 4168-88; Kriig, 1992). It was the first and to this day the only modern archaeological excavation in the Norden block. The southern part of the block was excavated in 1927-1931 (see Norden 19) and during various street and utility improvements on Stortorget in the second half of the 20th century. 


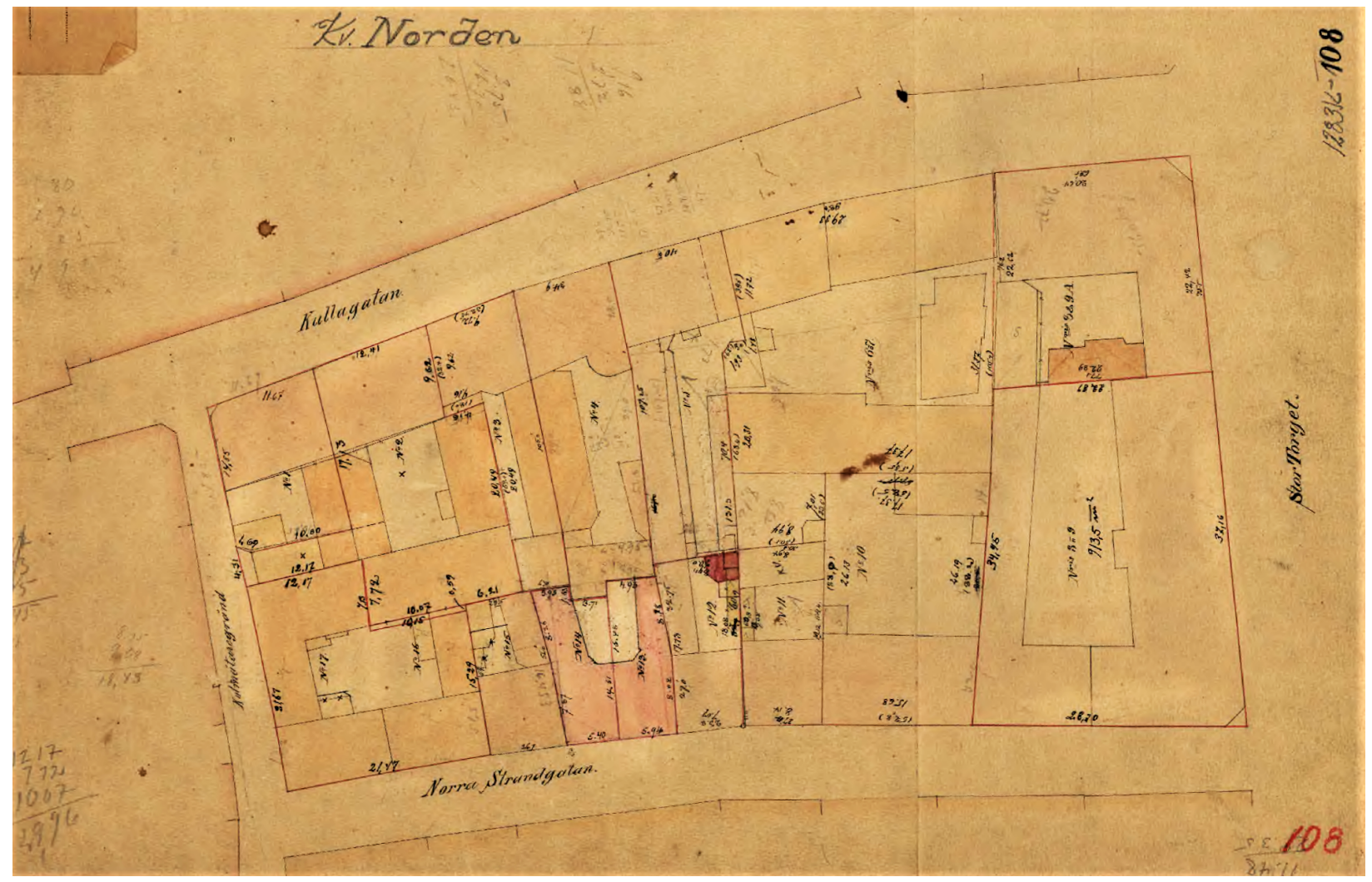

Figure 20: map of the Norden block, 1902. Lantmäteriets historiska kartarkiv.
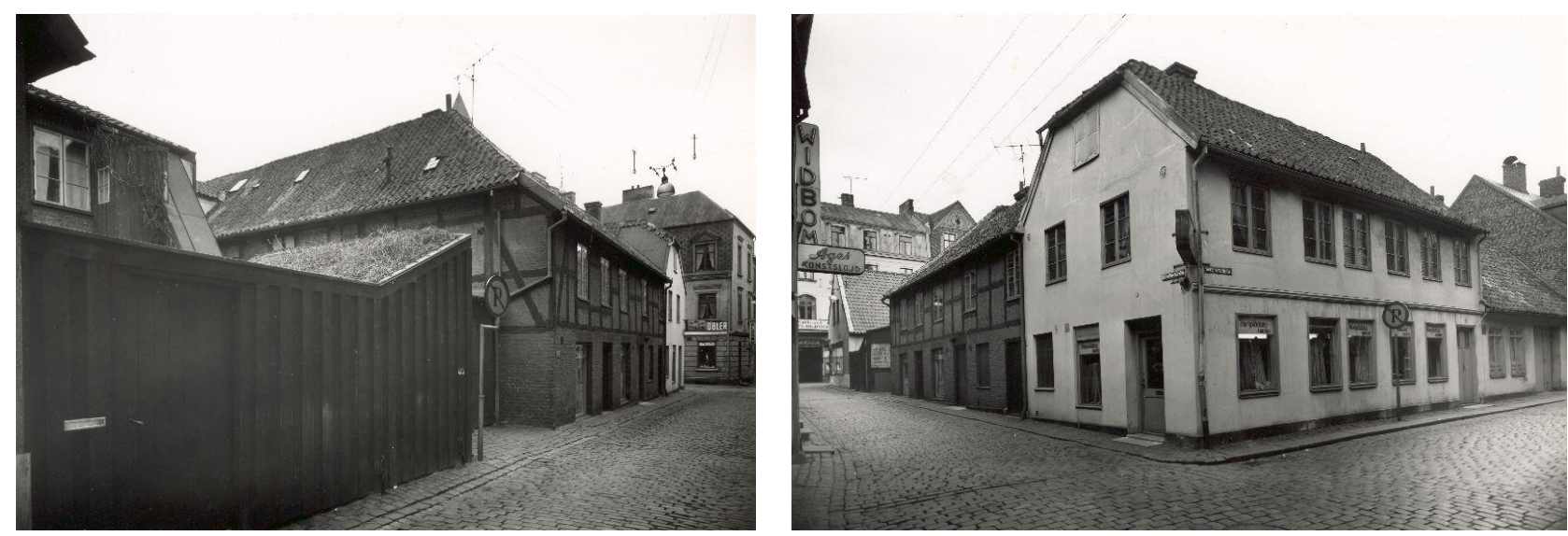

Figure 21: Norden 1 and 16/17 (now part of 24) from Kolmätaregränden and Norra Strandgatan in 1961. Photographer Otto Holmström. Helsingborgs museum.

According to Kriig (1992), the 1988 excavation uncovered three chronologically separate construction phases.

Phase 1: a seasonal herring fishing and processing area, with clay floors characteristic of the medieval shoreline of 1100-1200s Skåne and Denmark (Löfgren, 1992) and postholes from temporary shelters. There were no artefact finds from this phase. 
Fill layer: in the 1300-1400s the site was covered with landfill to expand the shoreline. Remains of two large oak posts were found which were most likely used to reinforce the shore.

Phase 2: fragmentary remains of a building with a fireplace along Kullagatan, as well as one or two buildings along Kolmätaregränden which date to the 1500s. A stone-paved yard had two stone wells and a gutter running from Kullagatan west towards the shore. The buildings were demolished after a short time and the site was covered with a large layer of landfill, possibly indicating that the shoreline was still unstable and in need of further reinforcing. Finds from phase 2 included post-medieval redware and stoneware ceramics, tiles, and two early and mid-1500s coins.

Phase 3: remains of the western and northern walls of a stone building situated along Kullagatan as well as the foundation of a $8 \times 4 \mathrm{~m}$ two-room timber frame building adjoining the larger stone house, with remains of a fireplace. The yard was paved with stones and bricks in a pattern. One of the wells from phase 2 appears to have been reused in phase 3 . The buildings were demolished in 1679. A silver coin dating to 1676 was found on the floor of the timber frame building. Multiple finds of canon and musket shots indicate that the area was a battle site during the 1676-1679 Scanian war.

\section{Finds from Norden 24}

There were a total of 414 finds from the site, although only a portion of them could be placed in the context of a specific phase due to the large amount of landfill. The two main groups of finds were household waste and building rubble. Among the other finds were two complete cannonballs weighing respectively 3350 and $2515 \mathrm{~g}$, a crossbow bolt, two iron knives, a bone needle, a fragmented glass bottle, a rosary made of antler, and eight tobacco pipes. Two of the three coin finds have been identified and date to 1513-1523 and 1676.

Post-medieval redware dominates the finds and at 7469 grams comprises $90 \%$ of all the ceramic finds. The majority of it was found in phase 3 , in the 1600 s building context. Phase 3 also contained 19 fragments of glazed redware stove tiles, weighing $2095 \mathrm{~g}$. For reasons mentioned earlier, I have not included stove tiles in the totals of ceramic finds.

The finds from Norden 24 are stored at Lund University Historical Museum with inventory number 30039 .

Table 1. Ceramic finds from Norden 24.

\begin{tabular}{|c|c|c|c|}
\hline Type & Weight $\mathrm{g}$ & Count & Percentage \\
\hline blackware & 390 & 18 & $4.70 \%$ \\
\hline medieval whiteware & 228 & 10 & $2.70 \%$ \\
\hline post-medieval redware & 7469 & 241 & $90.00 \%$ \\
\hline stoneware & 204 & 9 & $2.50 \%$ \\
\hline faience & 4 & 1 & $0.10 \%$ \\
\hline Total & 8295 & 279 & $100 \%$ \\
\hline
\end{tabular}


Ceramic type by weight Norden 24

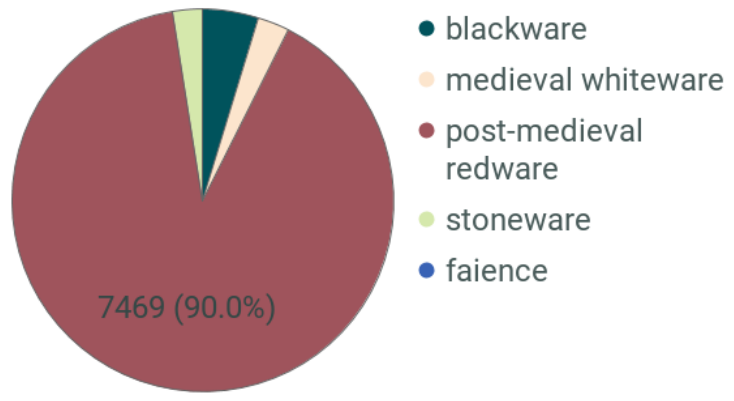

Figure 22: ceramic finds from Norden 24.
Ceramic type by weight, Norden 24

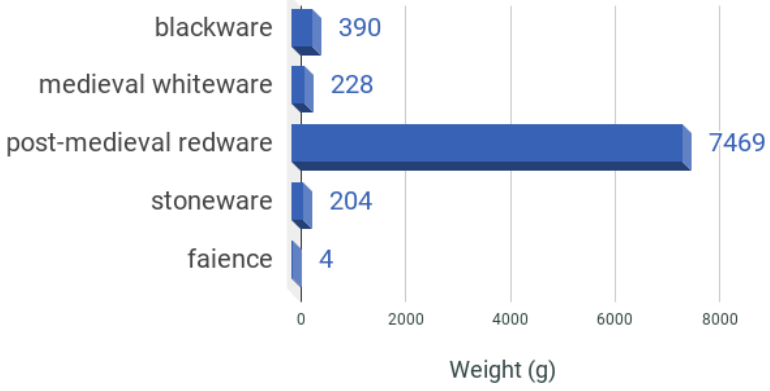

Figure 23: ceramic finds from Norden 24.

\section{Norden 19}

Block Norden 19 is located in the southern part of Norden, at the address Kullagatan 3. The building which is currently housing Carl Hoff jewellers shop was built in 1927. The previous building on this site was demolished in 1922 and was part of Norden 6/7 until the plot was split in two in 1927. Norden 6/7 was known as Strömbergska gården, after Strömberg's bicycle shop. As previously mentioned, the Norden block was close to the medieval shoreline and Kullagatan as a merchant street originated in the 1300s. The block extended over the modern day Stortorget until its demolition during the Scanian war in March 1679. The southern part of the block was not rebuilt and was paved over when Stortorget was created as the city market square in 1692.

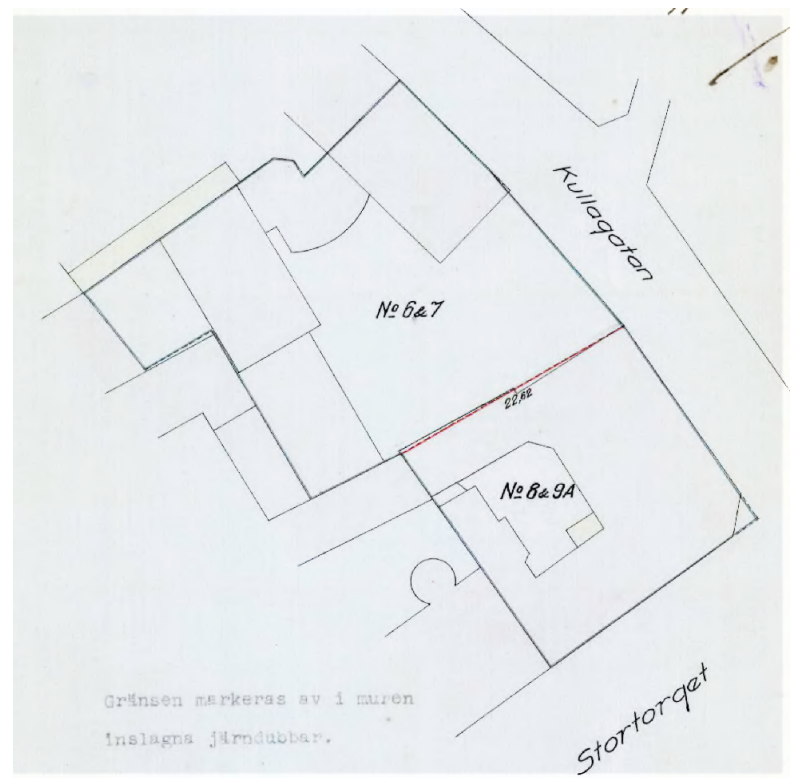

Figure 24: plan of Norden 6/7, 1922. Lantmäteriets historiska kartarkiv.

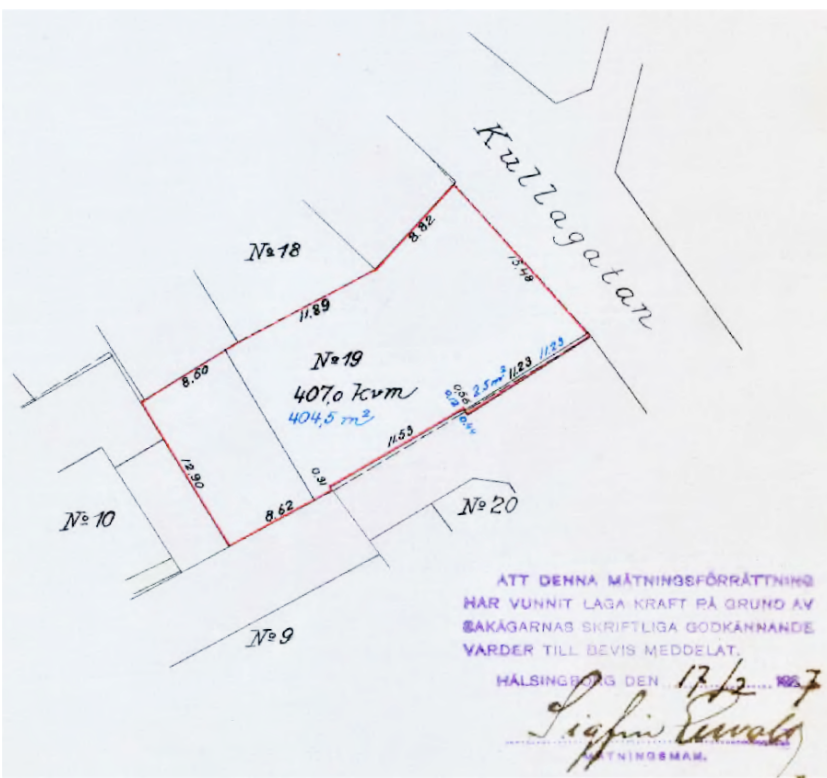

Figure 25: plan of Norden 19, 1927. Lantmäteriets historiska kartarkiv. 

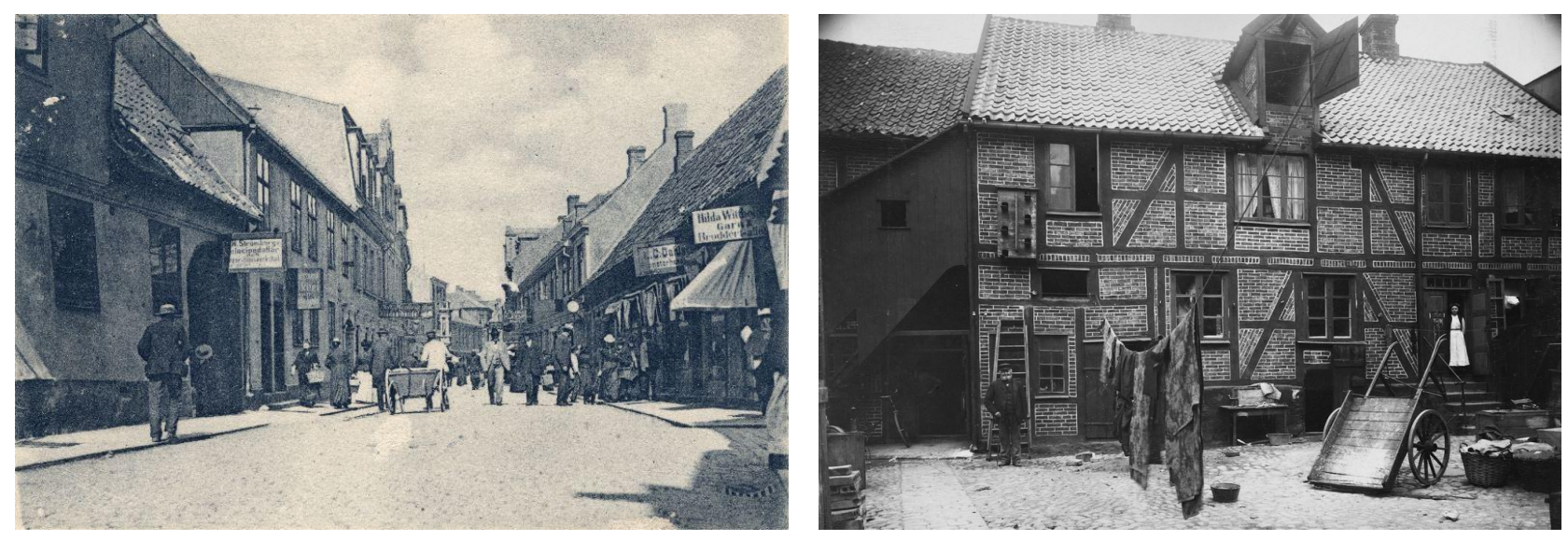

Figure 26: Kullagatan looking north in 1898. Kullagatan 3 is on the left with Strömberg's bicycle shop sign. Helsingborgs

Figure 27: the yard of Kullagatan 3 in 1905. museum.

Photographer Alfred B. Nilson. Helsingborgs museum.

The site at Norden 19 was excavated in 1927 in connection with a new construction on the empty plot. The excavation gets a brief mention in the Helsingborg museum annual report for 1927 as one of the two sites in the city with the most significant archaeological finds, the other site being Fågelsångsgatan 23. Both sites were excavated by Torsten Mårtensson, the director of the Helsingborg museum.

No archaeological reports exist for these urban excavations in the 1920s and 1930s. This work can be best described as salvage archaeology, where the Helsingborg museum curators visited construction sites and, with the assistance of property owners and construction workers, picked up loose finds. Several such excavations are mentioned in one or two paragraphs in each of the annual reports published by Helsingborg museums since 1912, with the most attention given to unusual singular finds and no details on excavation specifics.

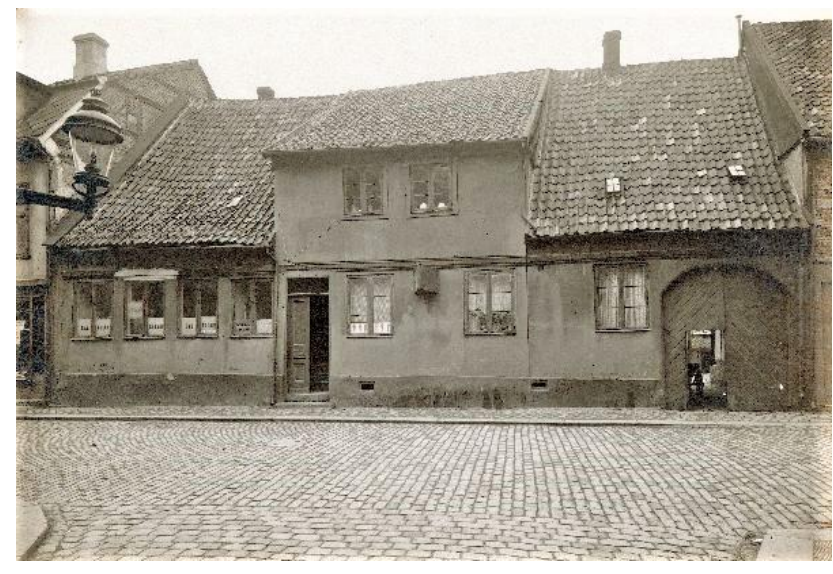

Figure 28: Kullagatan 3 in 1921 from the street. Helsingborgs museum.

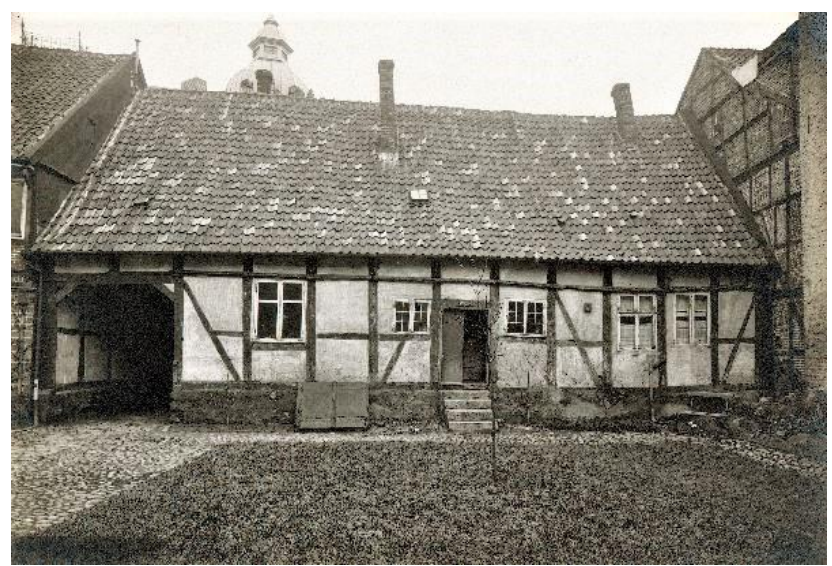

Figure 29: Kullagatan 3 in 1921 from the yard. Helsingborgs museum. 


\section{Finds from Norden 19}

Only four of the finds appear to be registered in the museum collections in 1927: a Westerwald stoneware jug (797-27) (Figure 27), a sherd from a similar jug (798-27), a fragment of a glass beaker (793-27), and a decorated wine glass (794-27) (Figure 28), all of the above finds dating to the 1600s. The Westerwald jug and the wine glass are currently on display at Dunkers Culture House. Additionally, a collection of stove tile fragments dating to the 1500-1600s has been registered as originating at either Fågelsångsgatan 23 or Kullagatan 3.

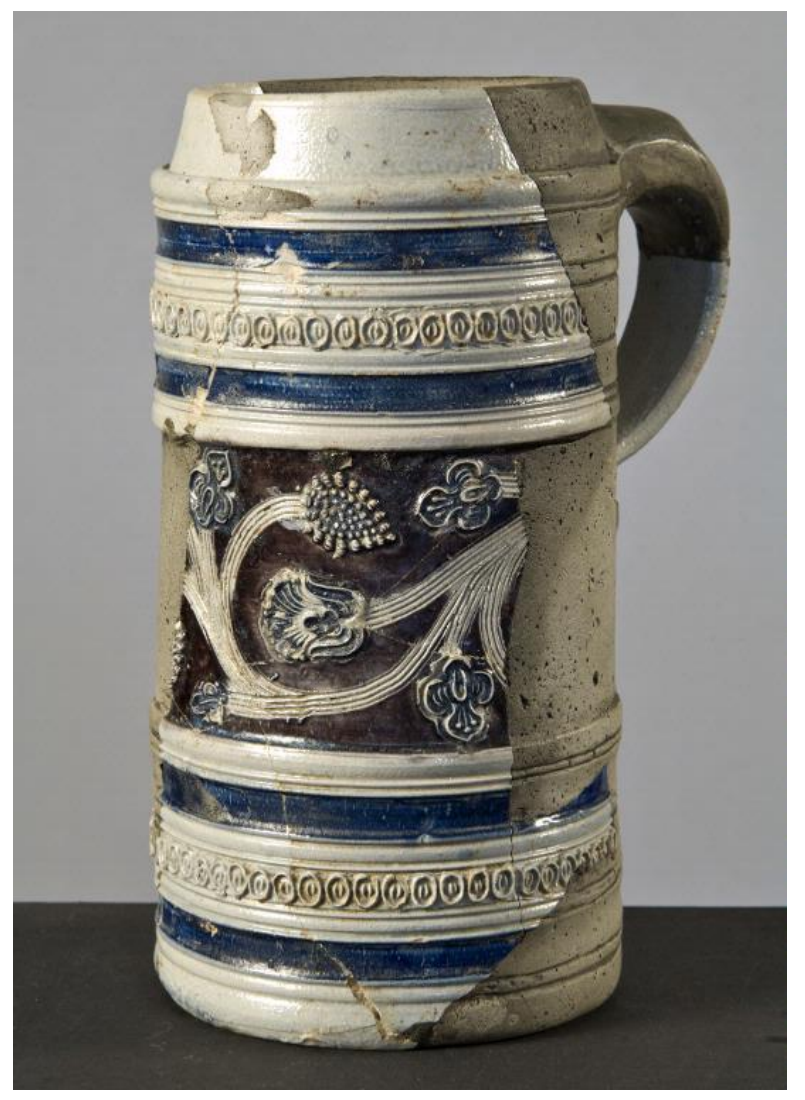

Figure 27: Westerwald stoneware jug, mid-1600s (797-27). Helsingborgs museum.

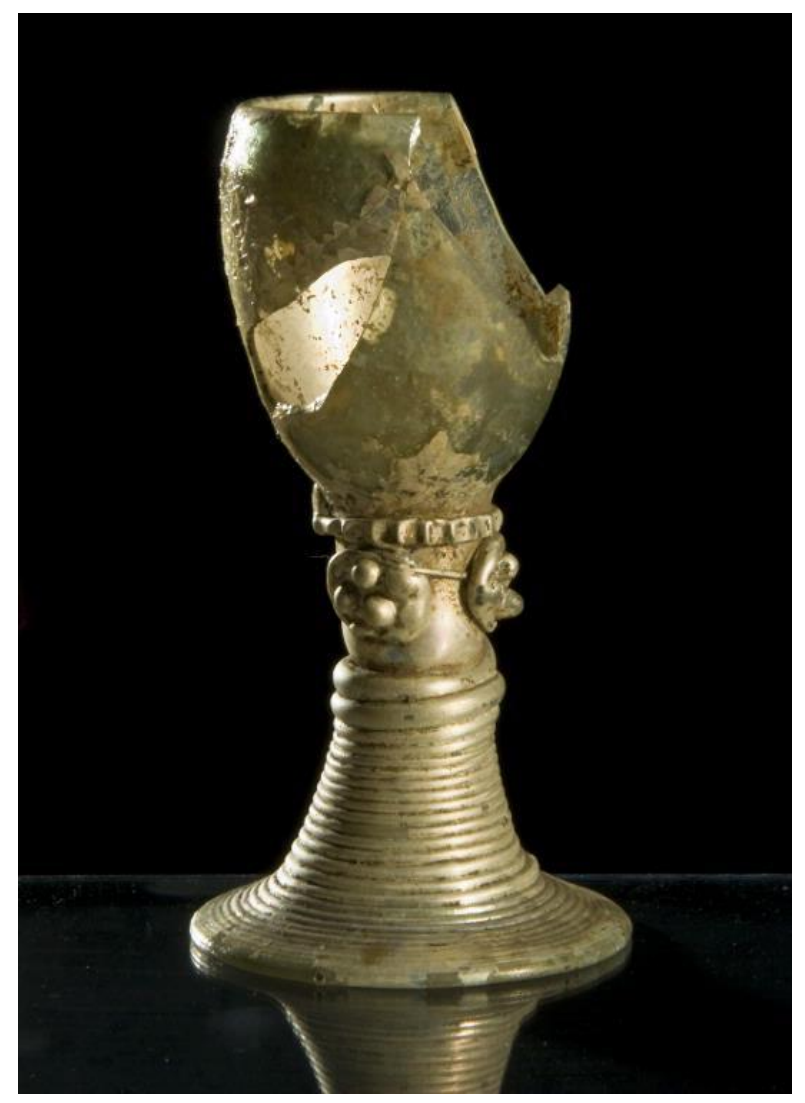

Figure 28: wine glass (römer), 1600s (794-27). Helsingborgs museum.

It is unclear if there are any non-ceramic finds from Norden 19 in the Helsingborg museum storage that have not yet been registered. In May 2020, I registered ceramic artefacts from Norden 19 in the Carlotta database with inventory numbers 1695-2020 to 1755-2020. More than half (56.5\%) of the ceramic finds from Norden 19 comprise post-medieval redware, with $66 \%$ of it most likely of either local or Danish origin. Among the finds were also two sherds of either Weser or Werra ware, four sherds of possibly German or Dutch light red wares, and 22 sherds of Dutch redware. The stoneware finds comprise almost exclusively 1800 s stoneware jugs and bottles, made locally in Helsingborg area, with the addition of three stoneware sherds from German mineral water bottles (1700-1800s) as well as three older Siegburg stoneware sherds, possibly dating to the 1400-1500s. Several non-ceramic finds were mixed in the storage box with the ceramic finds, for example, two rawhide hammer inserts (1712-2020) (Figure 33), two leatherworking bone tools (1713-2020) and a buckle casting mold (1721-2020) (Figure 34), all of unknown date. 
Table 2. Ceramic finds from Norden 19.

\begin{tabular}{|c|c|c|c|c|c|}
\hline Type & & & Weight & Count & Percentage \\
\hline blackware & & & 360 & 10 & $5.30 \%$ \\
\hline medieval redware & & & 195 & 3 & $2.90 \%$ \\
\hline \multirow[t]{6}{*}{ post-medieval redware } & & & 3855 & 83 & $56.50 \%$ \\
\hline & local or Danish & & 2630 & 55 & \\
\hline & imported & & 1225 & 28 & \\
\hline & & Weser/Werra ware & & 2 & \\
\hline & & Dutch redware & & 22 & \\
\hline & & German or Dutch light ware & & 4 & \\
\hline \multirow[t]{5}{*}{ stoneware } & & & 2230 & 88 & $32.70 \%$ \\
\hline & local, 1800s & & 2100 & 82 & \\
\hline & imported & & 130 & 6 & \\
\hline & & Siegburg stoneware & 55 & 3 & \\
\hline & & German, 1700--1800s & 75 & 3 & \\
\hline Dutch tin-glazed ware & & & 30 & 1 & $0.44 \%$ \\
\hline 1800s faience & & & 155 & 4 & $2.30 \%$ \\
\hline Total & & & 6825 & 189 & $100 \%$ \\
\hline
\end{tabular}

Post-medieval redware origin, Norden 19

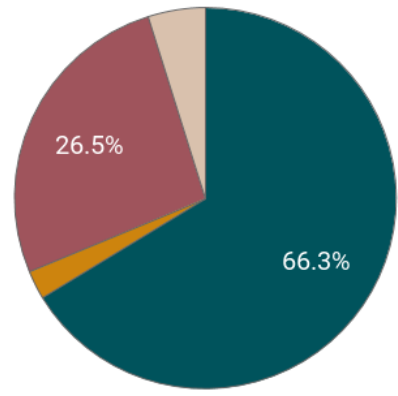

- Local or Danish

- Weser/Werra ware

- Dutch redware

- German or Dutch
Ceramic type by weight, Norden 19

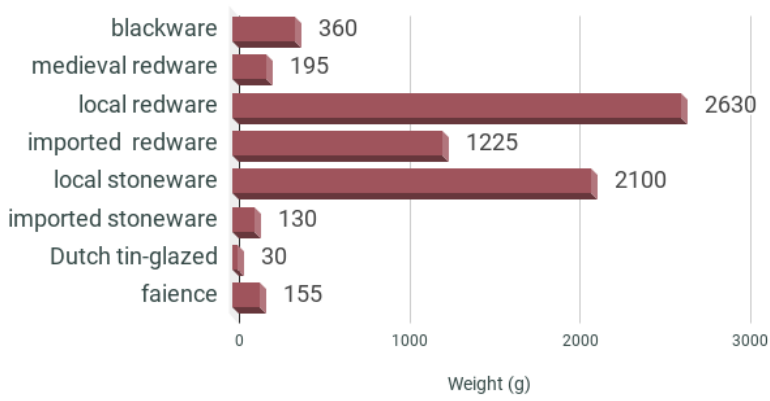

Figure 29: post-medieval redware origin, Norden 19.

Figure 30: ceramic finds from Norden 19. 


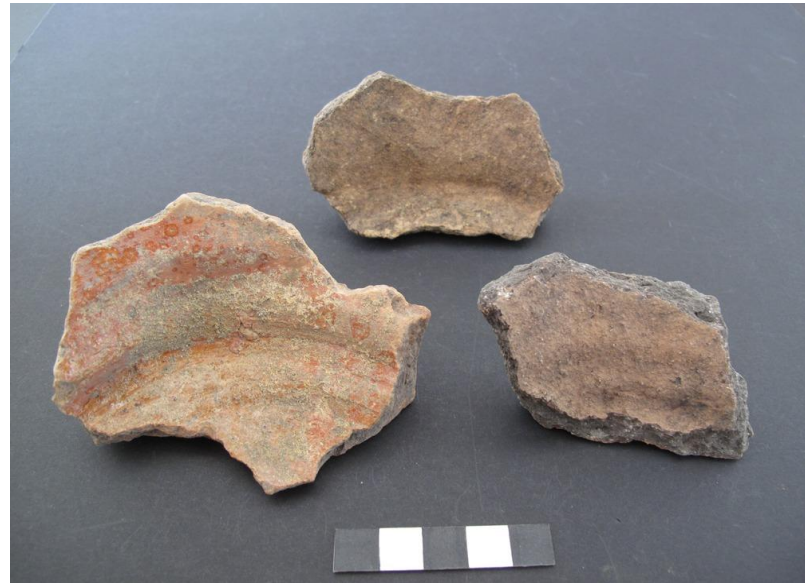

Figure 31: medieval redware fragments (1724-2020).

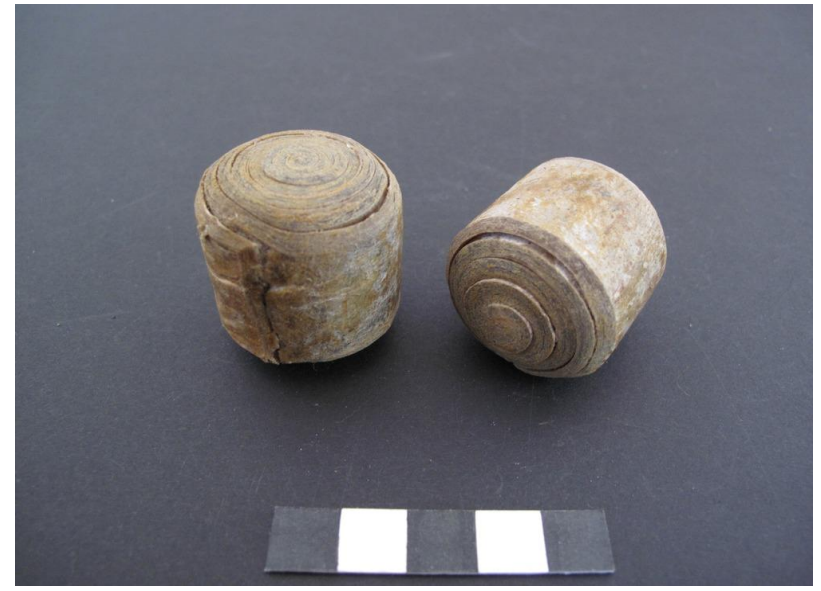

Figure 33: rawhide hammer inserts (1712-2020).

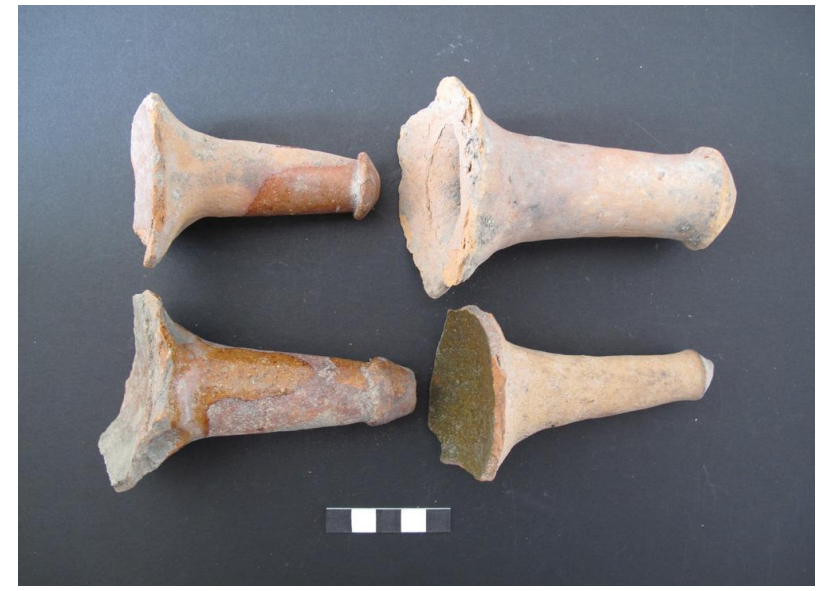

Figure 32: 1500-1600s cooking pot handles (1739-2020).

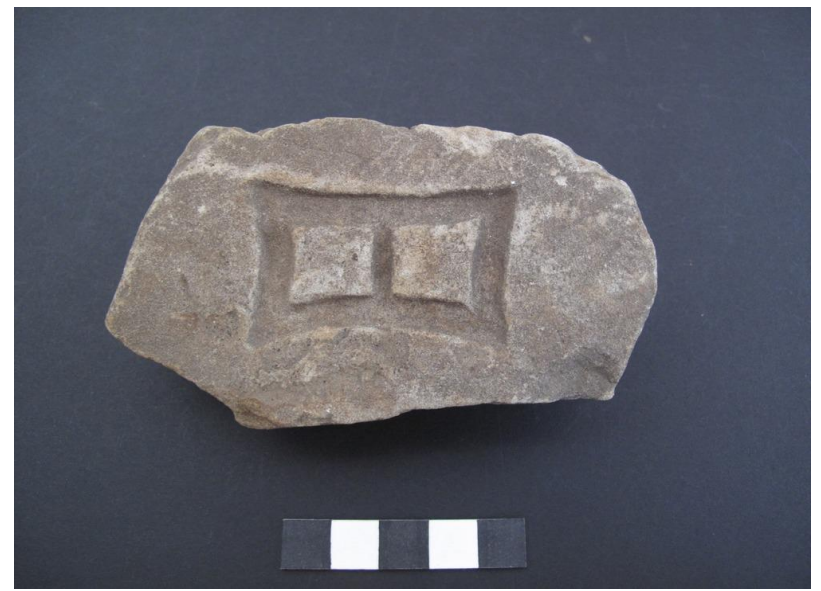

Figure 34: a buckle casting mold (1721-2020).

\section{Coin hoards from Norden block}

The site at Norden 19 is notable for a treasure hoard found under the cellar floor of an outbuilding in the yard of Kullagatan 3 . The object with inventory number 200-2002 comprises 41 artefacts found inside a wooden box. The box was fragmented and was not collected. Among the artefacts are two fragmented silver spoons, a silver book decoration, four gold coins, 29 silver coins and fragments of a silver chain. The coins date to between 1622 and 1676 and originate in Denmark, Sweden, Netherlands, Germany and one gold coin from the Ottoman Empire, from Murad IV's reign 1623-1640 (Figure 35) (Jonsson, 2018). The objects are on display in the "På gränsen" exhibition at Dunkers Culture House.

The Ottoman Empire coin is not the only golden coin with an Arabic inscription found in Helsingborg. In 1870, an "Eastern" golden coin with Arabic text on both sides was found in Helsingborg, at Långvinkeln block 8 and was registered at the National Historical Museum in Stockholm with inventory number 4434. It was one among eight foreign gold coins and 20 small Danish silver coins dating to the 1600 s found by Adolf Borg on his property in October 1870. 

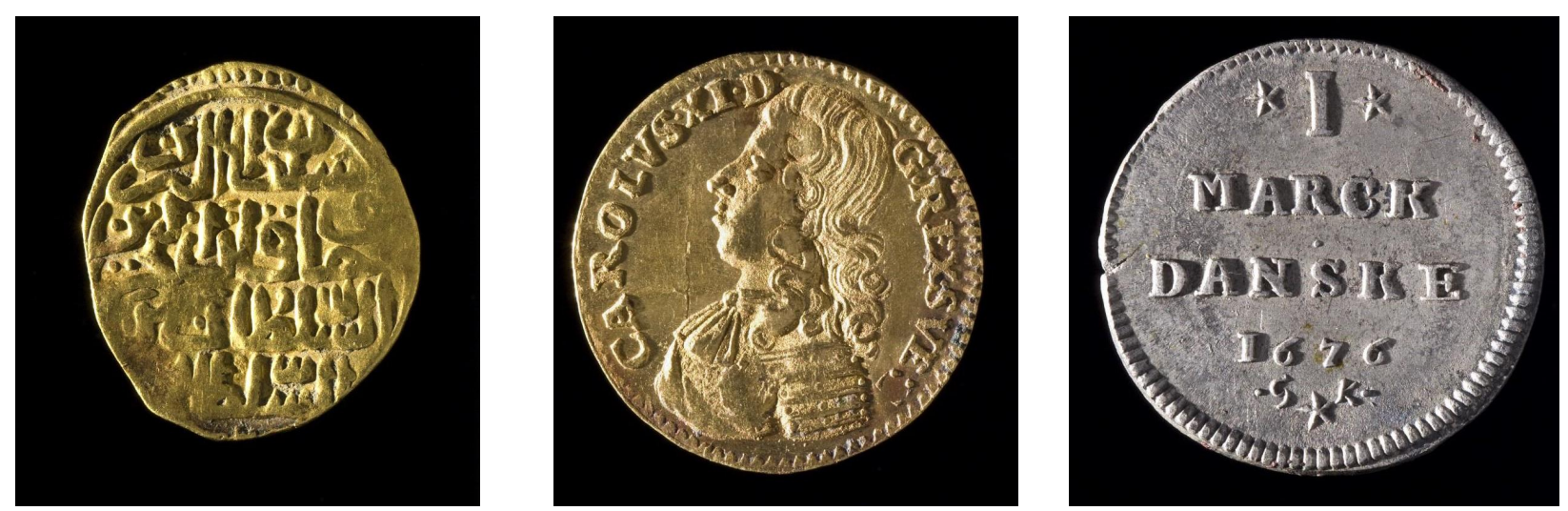

Figure 35: coins from the Kullagatan 3 hoard. Left to right: gold coin, Murad ibn Ahmad, Ottoman empire, 1623--1640; gold coin, Karl XI, Sweden, 1676; silver coin, 1 Danish mark, 1676. Helsingborgs museum.

A similar hoard was buried in the yard of the neighbouring property and found during road works along the northern edge of Stortorget in 1949. Knud Olsen Vognmand's hoard, named for the owner of the property demolished in 1679 , consists of a ceramic pot with a decorated lid from a different vessel which contained 192 silver coins, dating between 1617 and 1676. It was found dug into the clay floor of an outbuilding at the depth of $95 \mathrm{~cm}$ below the 1949 street level. The objects with inventory number 198-2002 are on display at Dunkers Culture House.

It is a rare occasion when a coin hoard can be almost certainly connected to a well-known historical person. Knud Olsen Vognmand was a wealthy guesthouse owner, a native of Helsingborg, who had previously participated in the war on the Danish side but had returned to Helsingborg during the subsequent Danish occupation. He was documented as present in Helsingborg in March 1679 but died in Helsingör in 1680, never having returned to collect his buried treasure (Johannesson, 1969d, p. 274). Of the coins, six are German, 119 Danish and 66 Swedish, including two coins minted in Swedish Estonia.

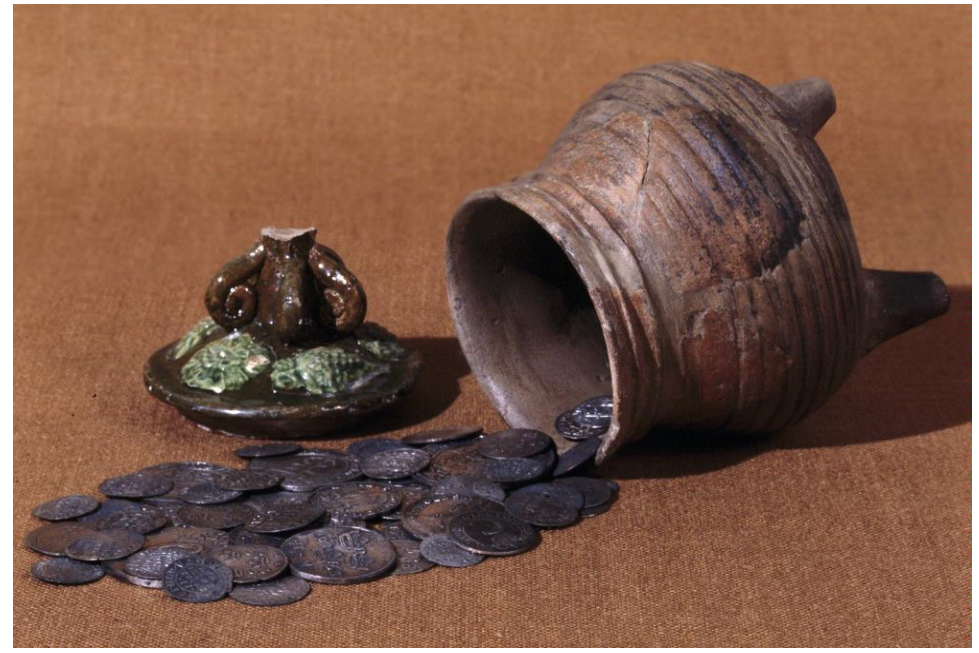

Figure 36: Knud Olsen Vognmand's hoard. Helsingborgs museum.

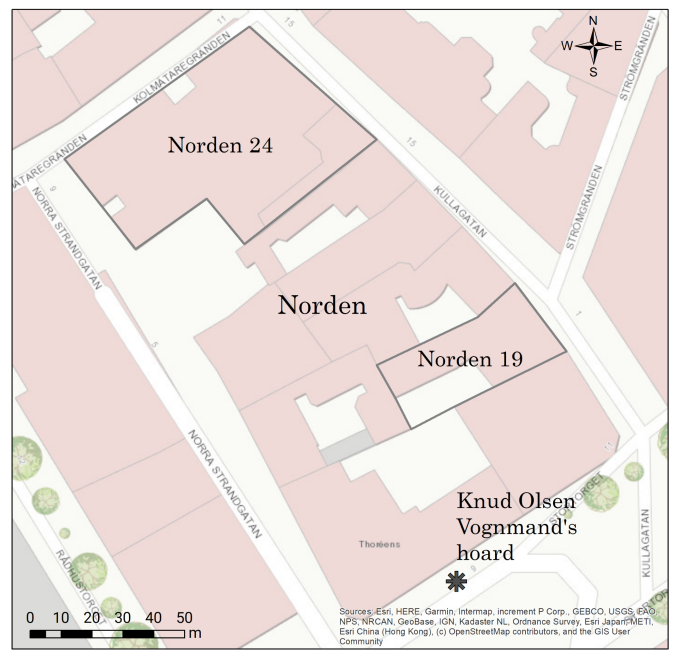

Figure 37: location of Knud Olsen Vognmand's hoard find in Norden block. 


\section{Karl XI Södra 20}

Karl XI Södra 20 block is located in the oldest part of the town, on the corner of Södra Storgatan and Karlsgatan. Already on the 1679 map of Helsingborg the shape of the buildings with an alley leading into a yard is the same as it remained until the early 1900 s. The southern buildings of the property (Södra Storgatan 18) were left standing in 1679 when the rest of the lower town was demolished. Södra Storgatan is the medieval road leading out of town towards Landskrona. The earliest town market was located along the street south and north of St. Maria church, where the street was wider than usual (Johannesson, 1969a).

Block Karl XI was split into north and south by building a street in 1905 . The new street Karlsgatan (older spelling Carlsgatan) bisecting Carl Christian Trapp's tannery was planned by Trapp's son, businessman and consul Oscar Trapp, who lived at Köpmannens house at Södra Storgatan 18, built in 1886. Karlsgatan was the first street in the town to use wooden blocks as pavement to minimise traffic noise. However, the durability of such road surface was poor (Helsingborgs stadslexikon). The 1700s property then known as "Trappska gården" was split into two, with the new street running diagonally across it in the middle. The only surviving buildings of Trappska gården are at Södra Storgatan 14, the two-storey house built around 1750 and the one-storey building around 1770. The old buildings at Södra Storgatan 16 were demolished in 1930. An excavation of the site is mentioned in the Helsingborg museum annual report for 1930 but no excavation report exists. A site on the opposite side of Karlsgatan at Karl XI Norra 18 was excavated by UV-Syd in 1981 and 1984, finding clay floors related to fish processing from the 1100-1200s as well as a medieval and post-medieval cultural layer (Wihlborg, 1992).

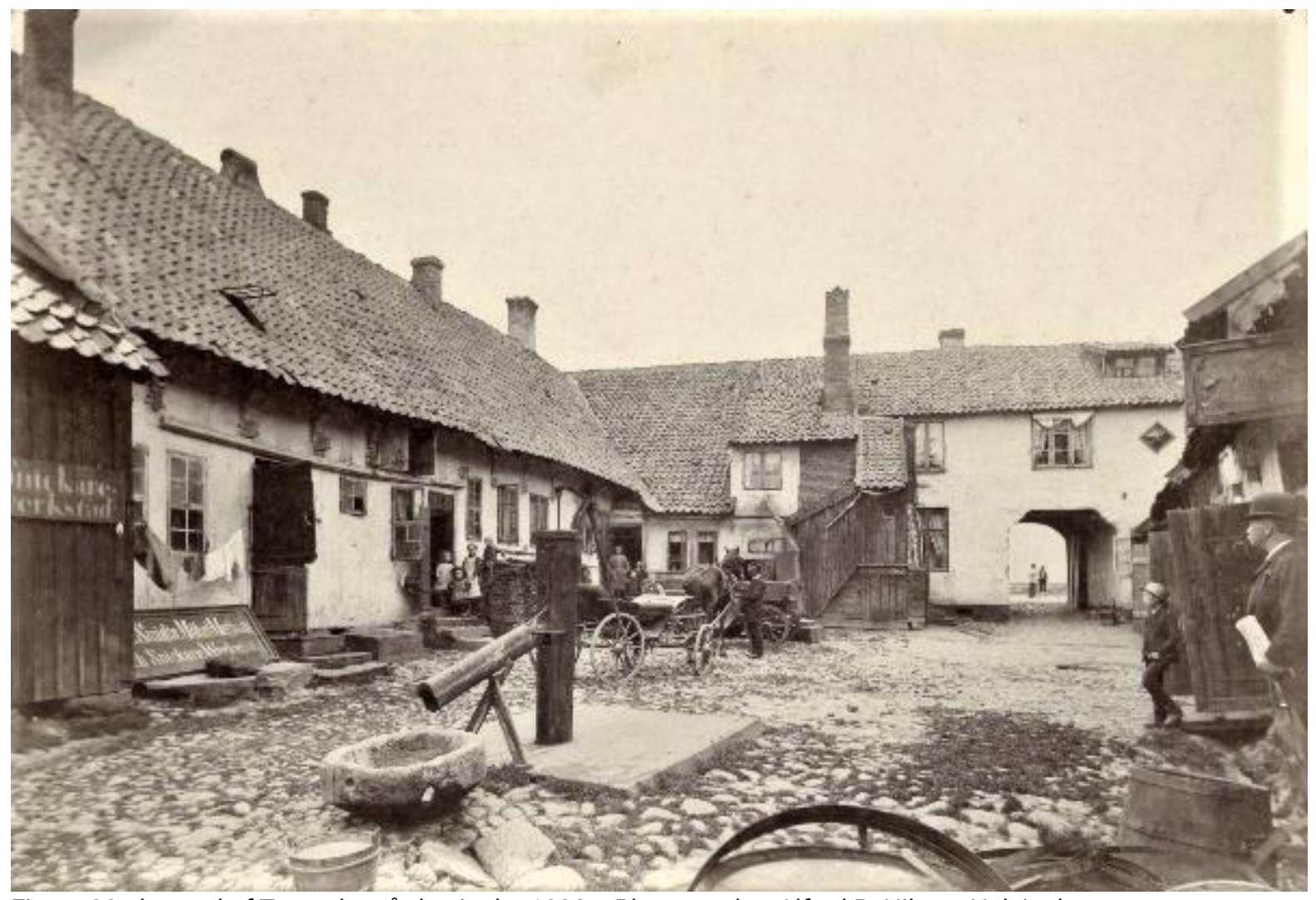

Figure 38: the yard of Trappska gården in the 1890s. Photographer Alfred B. Nilson. Helsingborgs museum. 


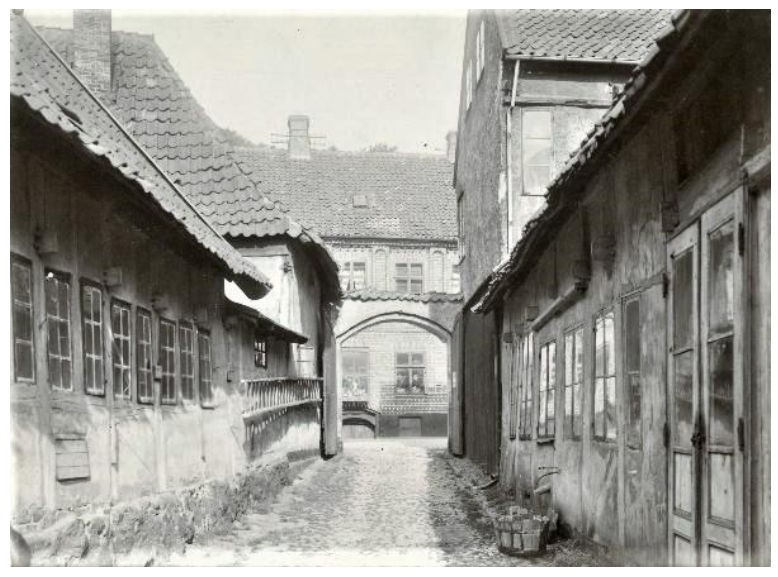

Figure 39: the alley between Södra Storgatan 16 and 18 in the 1890s. Helsingborgs museum.

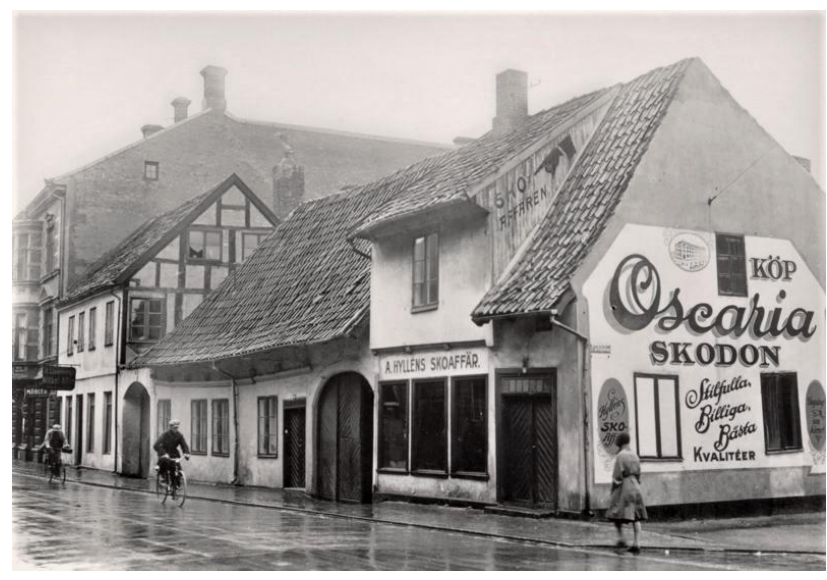

Figure 40: Södra Storgatan 16 with A. Hyllen's shoe shop in the 1920s. Helsingborgs museum.

\section{Finds from Karl XI Södra 20}

Helsingborg museum's annual report for 1930 briefly mentions a few outstanding finds from Södra Storgatan, a beautiful sculpted wooden beam from the early 1600 s from Johan Andersen's house at Södra Storgatan 18 and several decorative sandstone elements of a mantelpiece in Renaissance style from Söfren Nielsen's house at Södra Storgatan 16 (Figure 45 and 46). The Helsingborg museum collections hold 53 registered ceramic finds from Karl XI Södra 20, dating to 1300-1800s, with inventory numbers 893-922-2020 and 1277-1300-2020.

The majority of ceramic finds are post-medieval redware (91\%) with $72 \%$ of it of local or Danish origin, among them a significant number of tripod pipkin handles and feet dating to the 1500-1600s. Imported post-medieval redware is represented by fragments of Weser or Werra ware plates, Dutch redware pots and porringers, German or Dutch light wares and 19 sherds of undetermined origins. Stoneware includes one bottom fragment of a Siegburg Jakobakanne dating to the 1400-1500s and three sherds of 1600s Westerwald jugs. Among the finds are also several faience and porcelain sherds, likely dating to the late 1700 s or 1800 s.

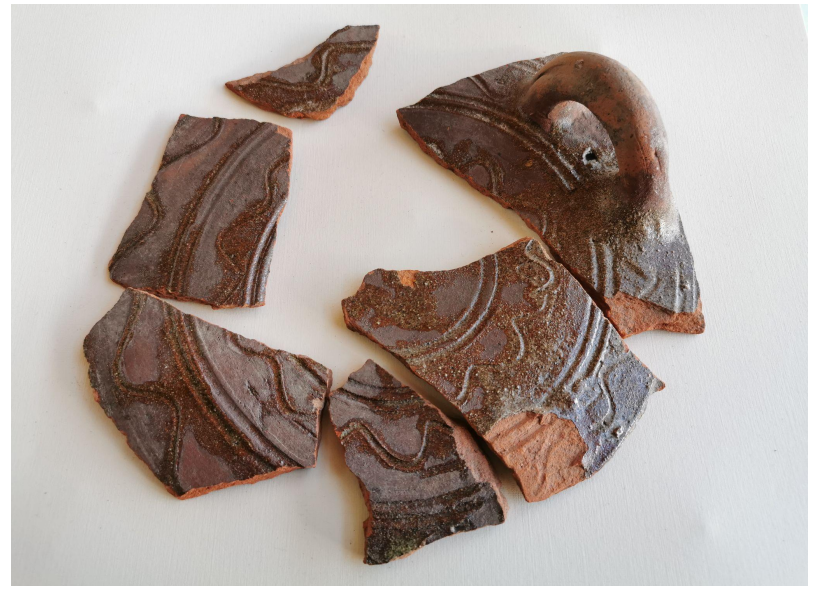

Figure 41: a "mystery" post-medieval redware lid with incised wave pattern and a handle on one side (1298-2020), its use could not be determined.

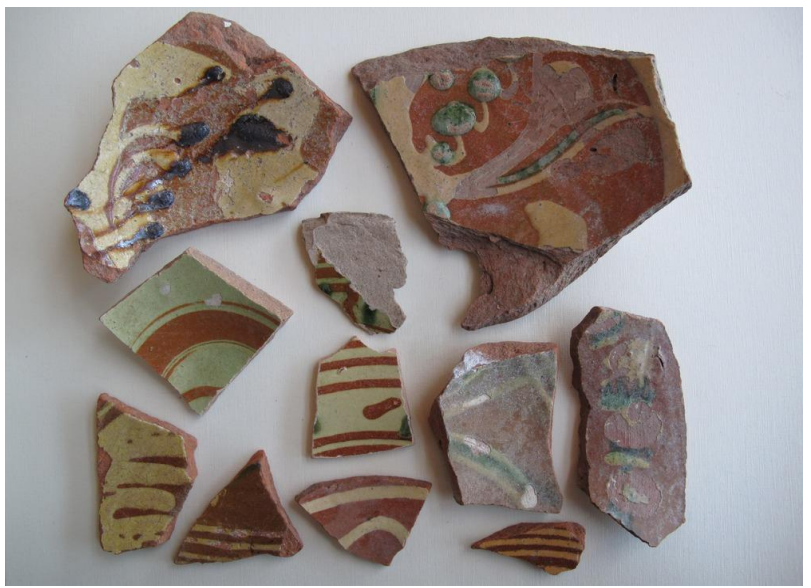

Figure 42: a sample of 1500--1600s plate fragments, Weser and Werra ware and Danish slipware. 
Table 3. Ceramic finds from Karl XI Södra 20.

\begin{tabular}{|c|c|c|c|c|c|}
\hline Type & & & Weight & Count & Percentage \\
\hline blackware & & & 500 & 4 & $2.90 \%$ \\
\hline medieval redware & & & 295 & 4 & $1.70 \%$ \\
\hline \multirow[t]{6}{*}{ post-medieval redware } & & & 15570 & 222 & $91 \%$ \\
\hline & local & & 12650 & 160 & \\
\hline & imported & & 2920 & 62 & \\
\hline & & Weser/Werra ware & & 14 & \\
\hline & & Dutch redware & & 22 & \\
\hline & & German or Dutch light ware & & 7 & \\
\hline \multirow[t]{4}{*}{ stoneware } & & & 440 & 12 & $2.60 \%$ \\
\hline & & Siegburg & 155 & 1 & \\
\hline & & Westerwald & 25 & 3 & \\
\hline & & Various German & 260 & 8 & \\
\hline faience & & & 275 & 18 & $1.60 \%$ \\
\hline porcelain & & & 35 & 4 & $0.20 \%$ \\
\hline Total & & & 17115 & 264 & $100 \%$ \\
\hline
\end{tabular}

Ceramic type by weight, Karl XI Södra 20

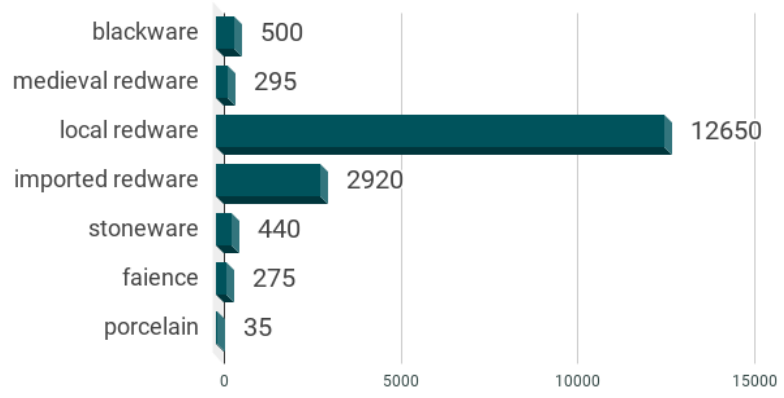

Post-medieval redware origin, Karl XI Södra 20

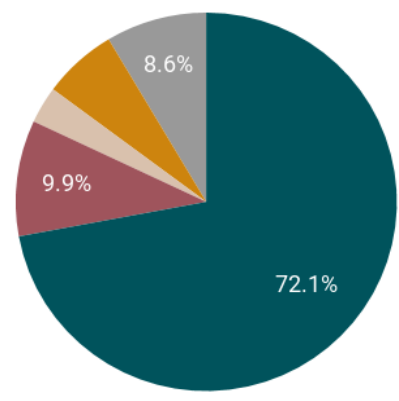

- Local or Danish

- Dutch redware

- German or Dutch

- Weser/Werra ware

- Other

Figure 43: ceramic finds from Karl XI Södra 20.

Figure 44: post-medieval redware origin, Karl XI Södra 20. 

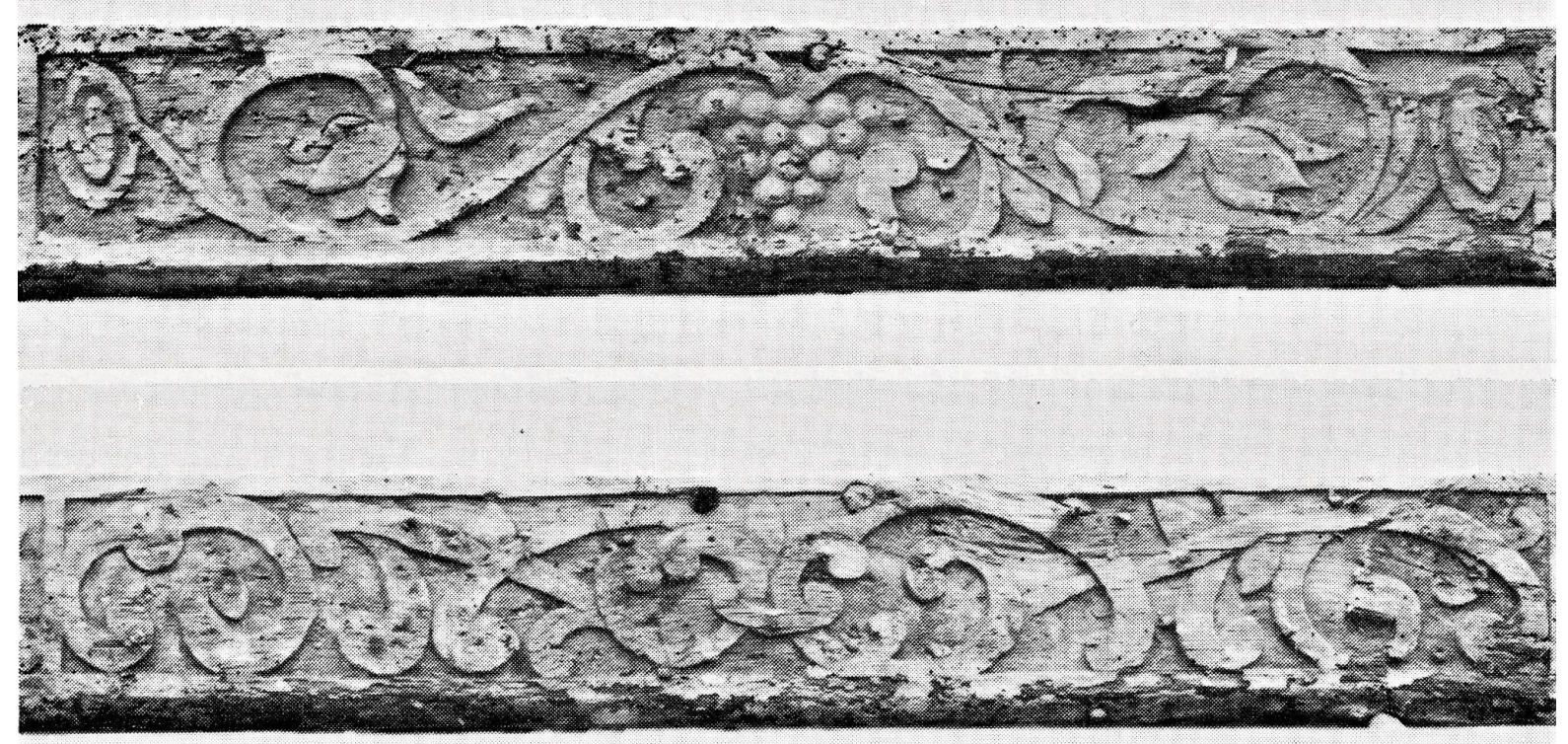

Figure 45: a wooden beam from Johan Andersen's house at Södra Storgatan 18. Andersen was an alderman (1605-1623) and traded in beer and wine. Helsingborgs museum.



Figure 46: mantelpiece fragments from merchant Söfren Nielsen's house at Södra Storgatan 16. Helsingborgs museum. 
The National Historical Museum in Stockholm holds in its collections a seal on a silver chain, previously owned by one Algotus Ryzia (or Reedtz), likely of the Mecklenburg family Reedtz and dating possibly to the 1300s. It was found in the ground in the middle of the Karl XI block number 4 (Trappska gården), on the third stone layer below the current one in 1899 and donated to the museum by Carl Christian Trapp.

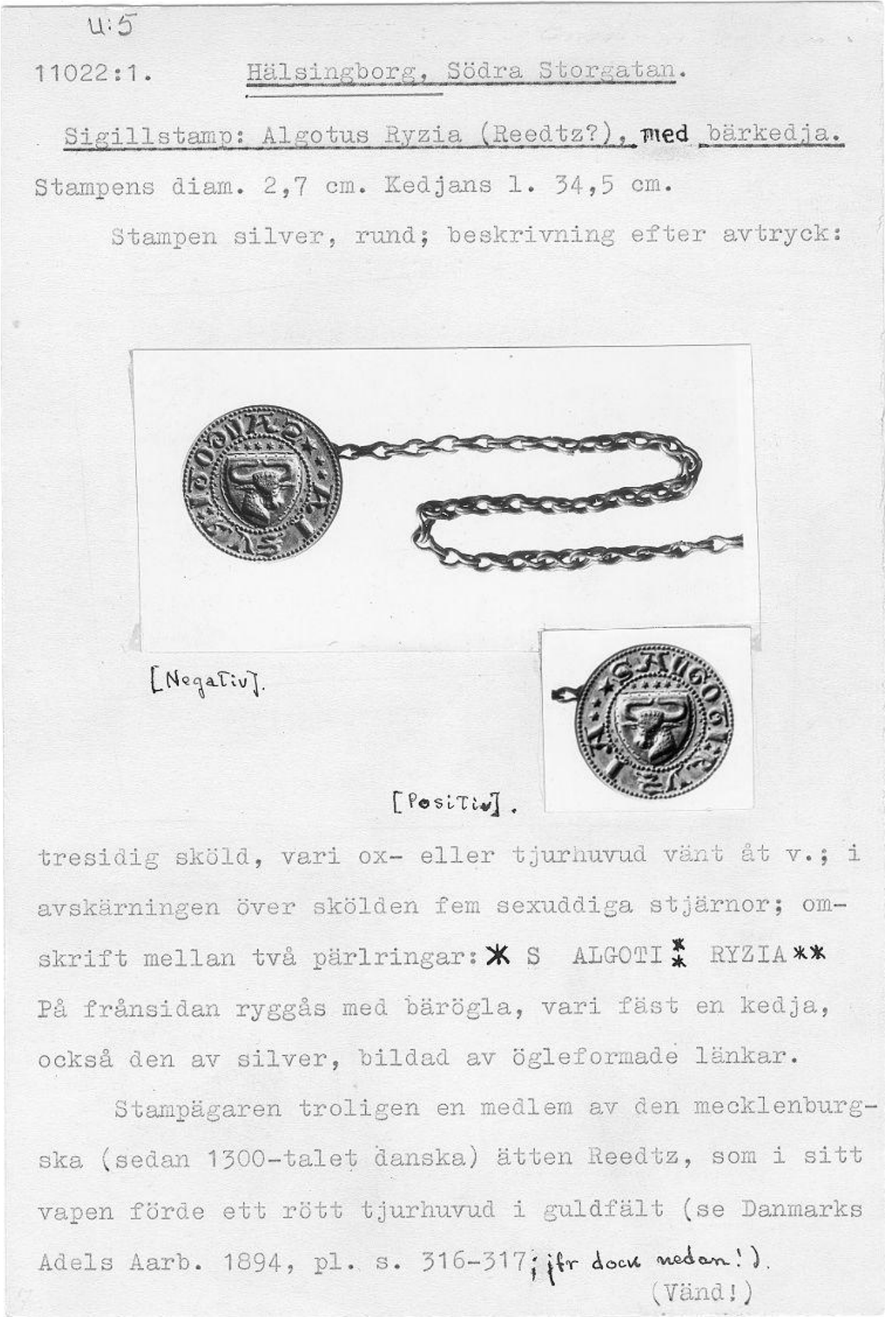

Figure 47: silver stamp of Algotus Ryzia, found at Karl XI in 1899. The National Historical Museum. 


\section{Färjan 4}

Färjan 4 block is chronologically the youngest site. The area was below the medieval shoreline and at least the western half of it was under water until the 1690s. There is no record of the exact dating of the first buildings in the block. On a 1788 map of Helsingborg, the eastern half of the block is built on and the western half extends to the shoreline, labelled as "Cobbler Nils Person's Field". The block to the east of it at the current location of Konsul Olsons Plats is labelled "Cobbler Nils Person's Plot". Previously the Färjan block was divided into Färjan 1, 2, and 3. A two-storeyed brick building stood along Norra Strandgatan and several small wooden buildings to the west of it. In 1929, the entire block was demolished and combined into Färjan 4 where the HD House was built. It is currently at the address Drottninggatan 20-22.

No excavation report from the site exists. We only know the year of excavation from the construction date of the HD House as well as archival photographs from the building site. However, there are 99 post-medieval ceramic objects from Färjan 4 in the Helsingborg museum collections with inventory numbers 1301-1306-2020, 1318-1347-2020, 1360-1410-2020, and 1681-1693-2020. Since the block did not physically exist until the late 1600s at the earliest, it cannot be said with any certainty whether all finds from this site were originally deposited there or if some of them were part of the 1680-1690s fill of the shoreline, likely containing rubble from buildings demolished elsewhere in town in 1679. A ground level measurement taken at the crossing of Norra Storgatan and Hästmöllegränden streets was $2.5 \mathrm{~m}$ above the sea level with a $1.5 \mathrm{~m}$ cultural layer (Wihlborg, 1981).

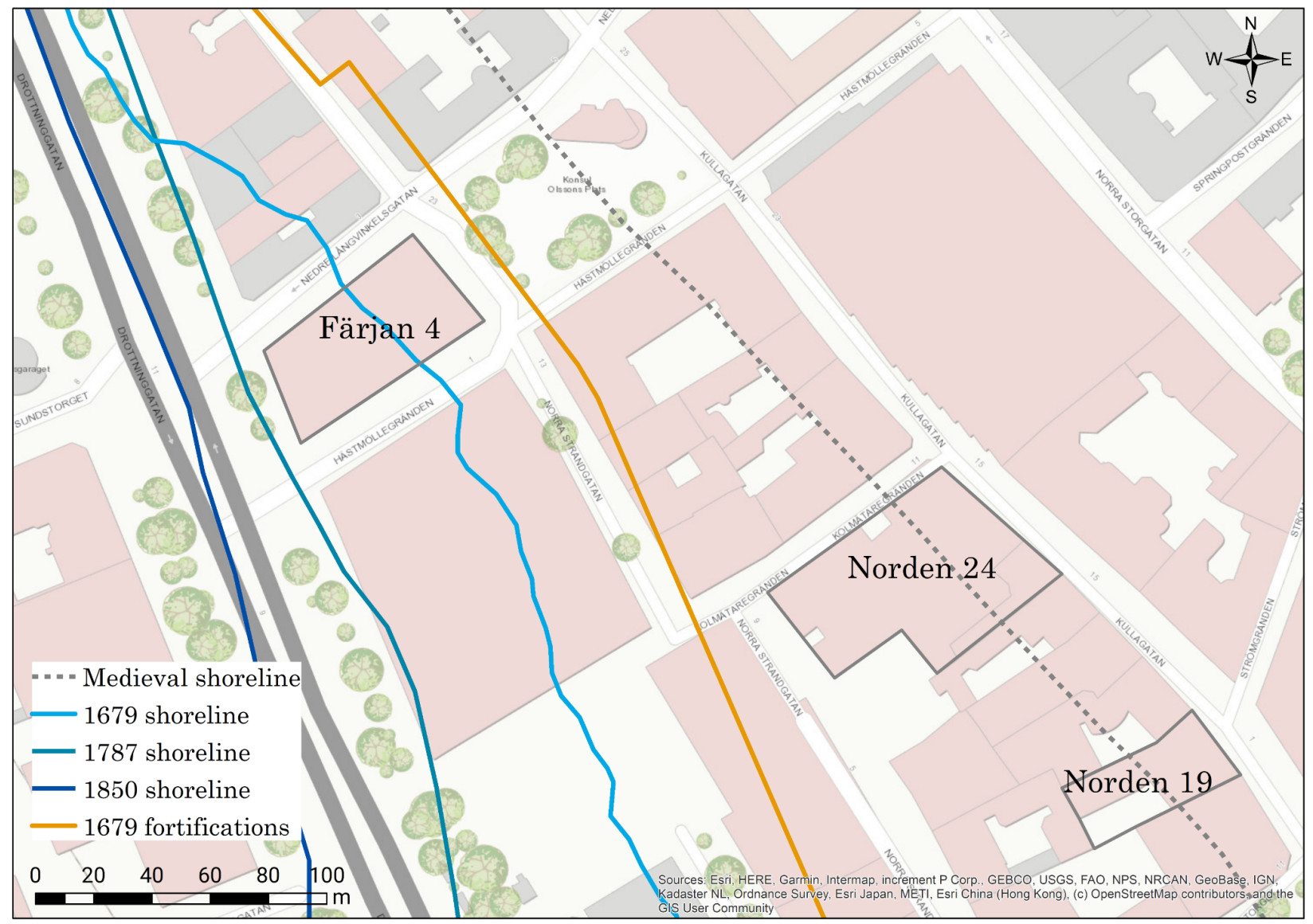

Figure 48: map showing Färjan 4 block in relation to historical shoreline and the 1600 s city fortifications. 


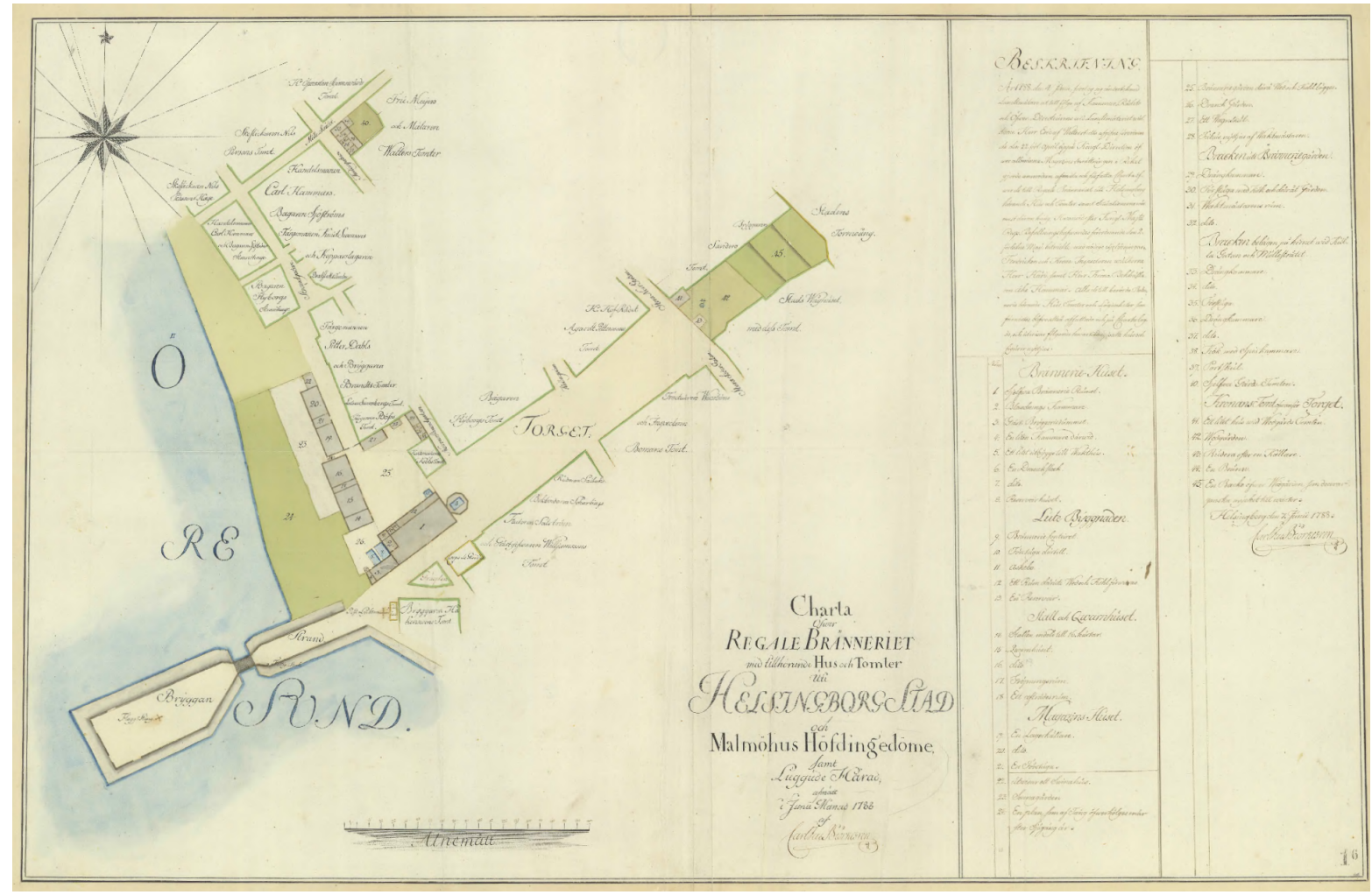

Figure 49: a 1788 map of Helsingborg marking the modern day Färjan block as cobbler Nils Person's property. Lantmäteriets historiska kartarkiv.

\section{Finds from Färjan 4}

More than two thirds of the ceramic finds from the site consist of post-medieval redware, with $43 \%$ of it made locally or in Denmark. Imported redware is represented by Dutch and German vessels, including cooking pot and porringer handles and a variety of slipware plate sherds, as well as several yet unidentified pottery fragments. Tin-glazed wares are present as both 1600 s Dutch majolica and Italian Berettino ware fragments. Among the more unusual objects are fragments of three decorated Delft tiles (1385-2020), a Qianlong porcelain platter (1384-2020), and two sherds of Capuchin ware (1403-2020). Stoneware finds consist predominantly of 1700s German bottle fragments.

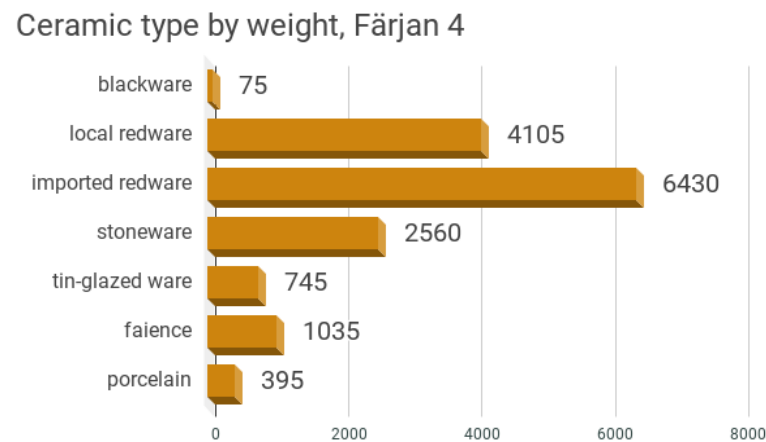

Figure 50: ceramic finds from Färjan 4.

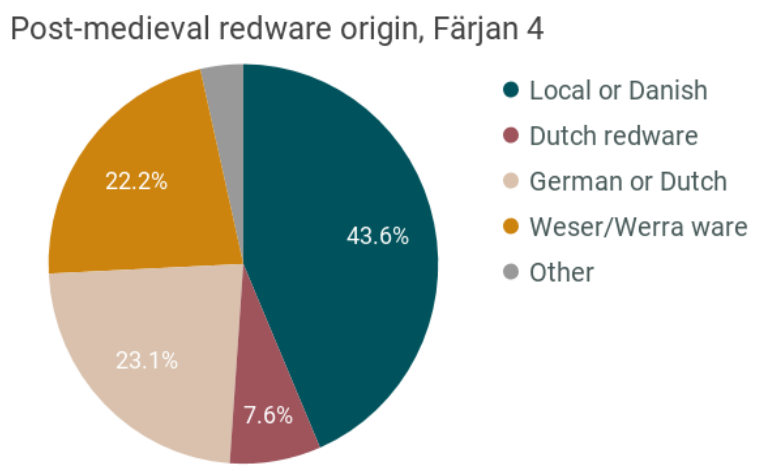

Figure 51: post-medieval redware origin, Färjan 4. 
Table 4. Ceramic finds from Färjan 4.

\begin{tabular}{|c|c|c|c|c|c|}
\hline Type & & & Weight (g) & Count & Percentage \\
\hline blackware & & & 75 & 1 & $0.49 \%$ \\
\hline \multirow[t]{7}{*}{ post-medieval redware } & & & 10535 & 255 & $68.70 \%$ \\
\hline & local & & 4105 & 98 & \\
\hline & imported & & 6430 & 127 & \\
\hline & & Weser/Werra ware & & 50 & \\
\hline & & Dutch redware & & 17 & \\
\hline & & German or Dutch light ware & & 52 & \\
\hline & & Other & & 8 & \\
\hline \multirow[t]{6}{*}{ stoneware } & & & 2560 & 42 & $16.70 \%$ \\
\hline & local & & 250 & 1 & \\
\hline & imported & & 2310 & 41 & \\
\hline & & Westerwald & & 2 & \\
\hline & & German mineral water bottle & & 23 & \\
\hline & & German other & & 16 & \\
\hline \multirow[t]{4}{*}{ tin-glazed ware } & & & 745 & 58 & $4.90 \%$ \\
\hline & & Dutch tin-glazed & & 43 & \\
\hline & & Berettino ware & & 3 & \\
\hline & & Other & & 12 & \\
\hline faience & & & 1035 & 48 & $6.70 \%$ \\
\hline porcelain & & & 395 & 8 & $2.60 \%$ \\
\hline Total & & & 15345 & 412 & $100 \%$ \\
\hline
\end{tabular}

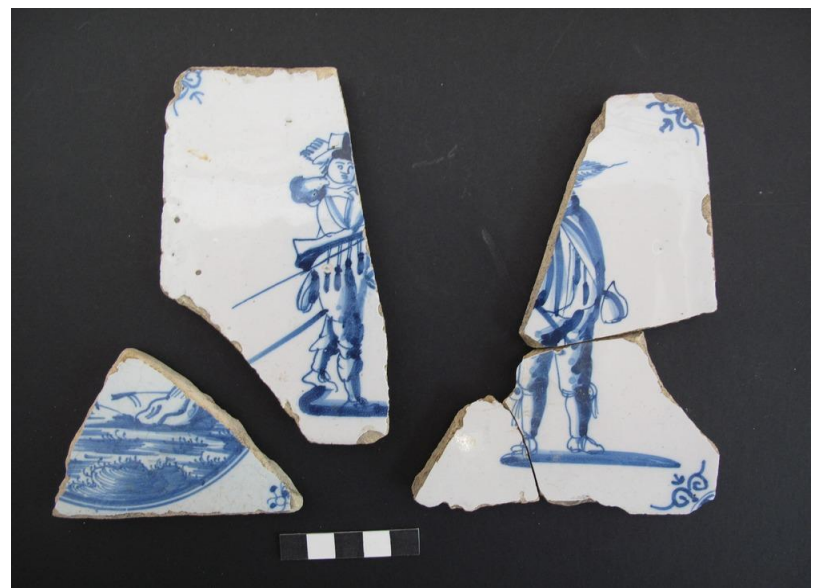

Figure 52: Delft tile fragments.

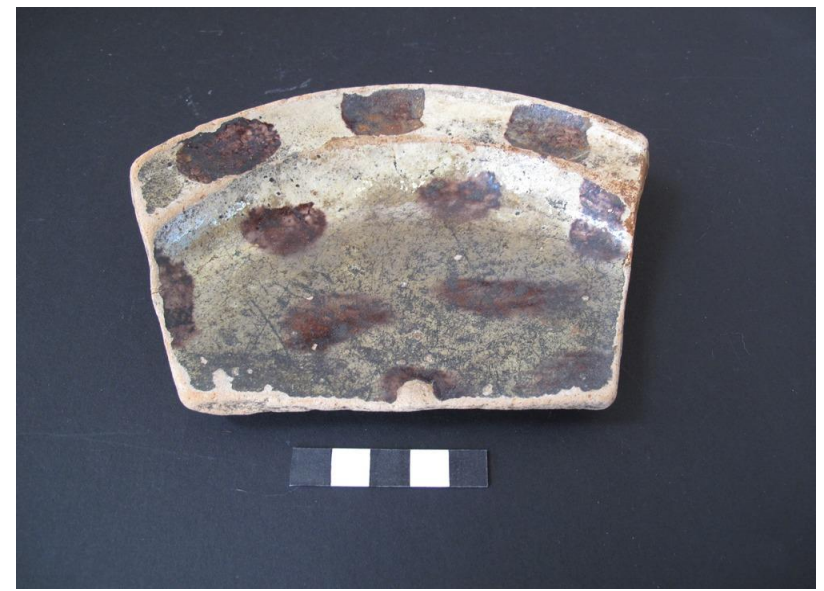

Figure 53: an imported redware fragment with an unusual glaze. 


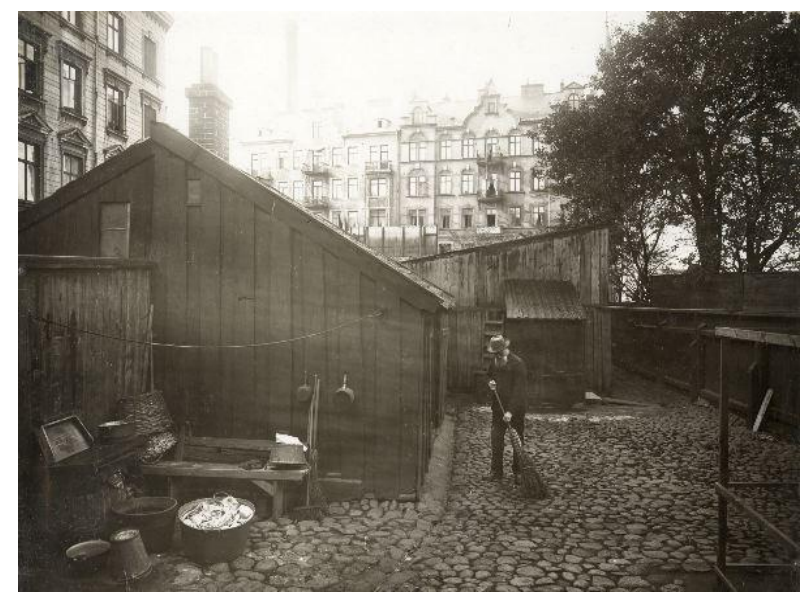

Figure 54: the owner of Färjan 1 (Drottninggatan 22), sea captain Carl Bohle in his back yard, in 1909. Photographer Alfred B. Nilson. Helsingborgs museum.

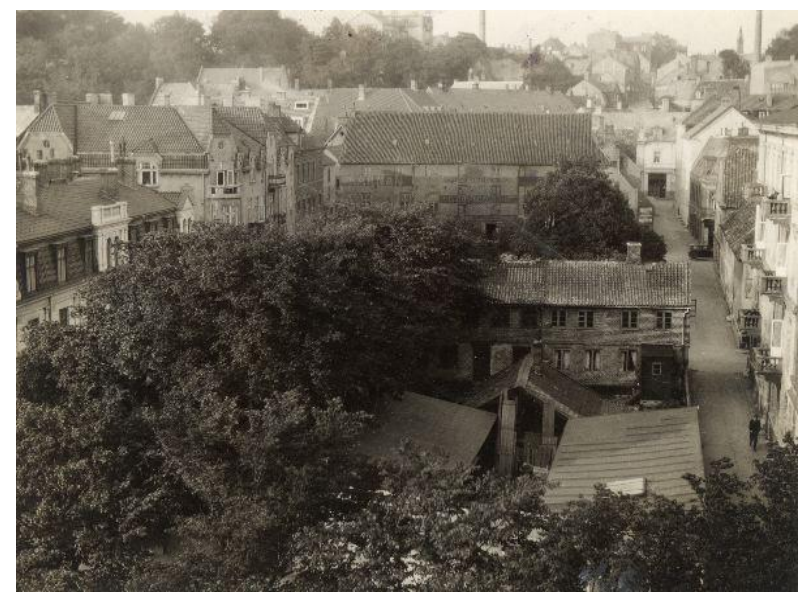

Figure 55: a view over Quarter Färjan in the late 1920s. Helsingborgs museum.

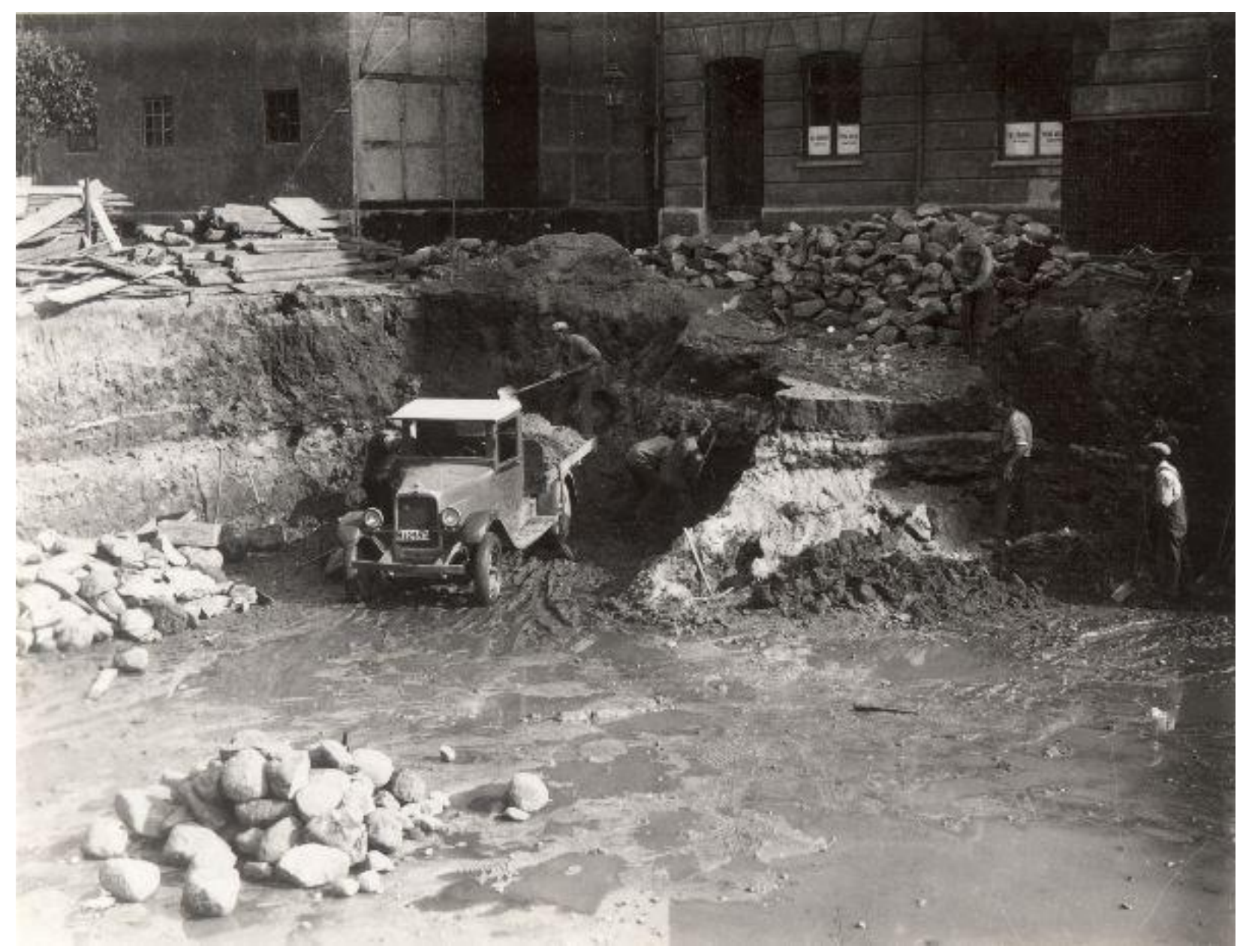

Figure 56: excavation of the foundations for the HD House, 1929. Helsingborgs museum. 


\section{Thalia 8}

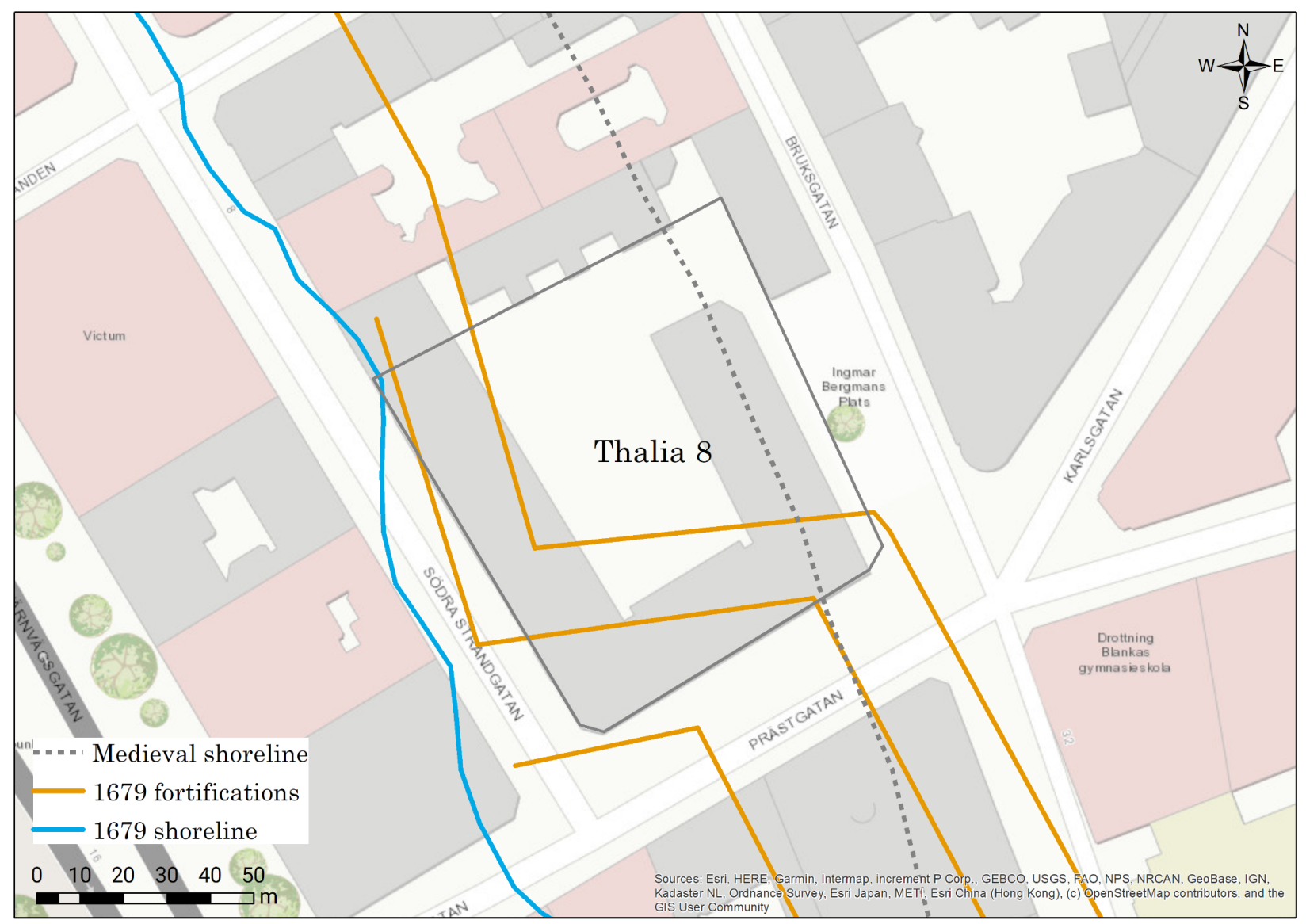

Figure 57: map of Thalia 8 block.

Thalia 8, the southern half of the modern day Thalia 20 block, is the site of the former Helsingborg city theatre. The first theatre at this location was a simple wooden structure known as teaterladan, built in 1817 on the corner of Prästgatan and Bruksgatan. At first its facade faced Bruksgatan but in the 1850s the whole building was moved several metres to face Prästgatan (Helsingborgs stadslexikon). Teaterladan was in use until 1875. The new theatre construction began in 1875 and was finished in 1878. Its first season opened in September 1877. In 1976, the theatre building was demolished, despite large public protests. The current apartment block on the site was built in 1985-1987.

In the medieval period, the area was directly on the shore of Öresund and was used for fishing and fish processing. An excavation in the 1980s to the south of Thalia block located a medieval boat landing (Löfgren, 1992). The shoreline was gradually filled in to the line west of the block in the 1600 s. When the city fortifications were built in the 1650 s, the Landskrona bastion was constructed directly over the Thalia 8 block. From 1798 to 1932, the Thalia block was next to the Ruuthska bruket ceramic factory, which was located over the current Ruuth and John Ericsson blocks. 

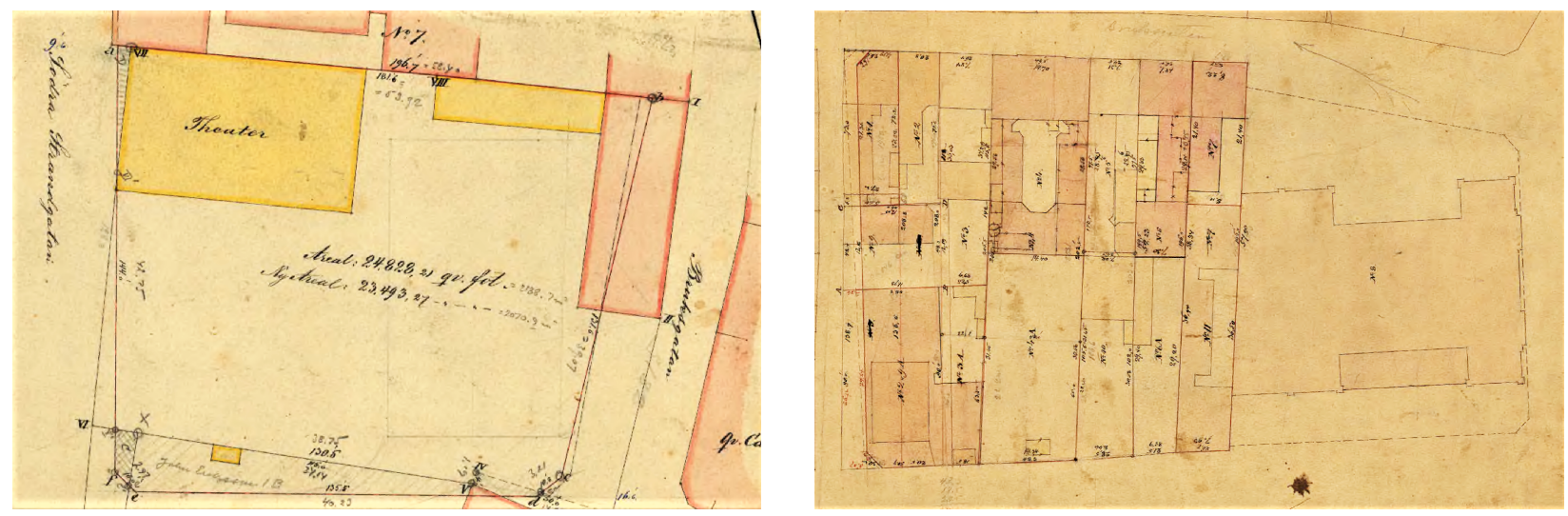

Figure 58: map of Thalia with the old theatre building, 1877. Lantmäteriets historiska kartarkiv.

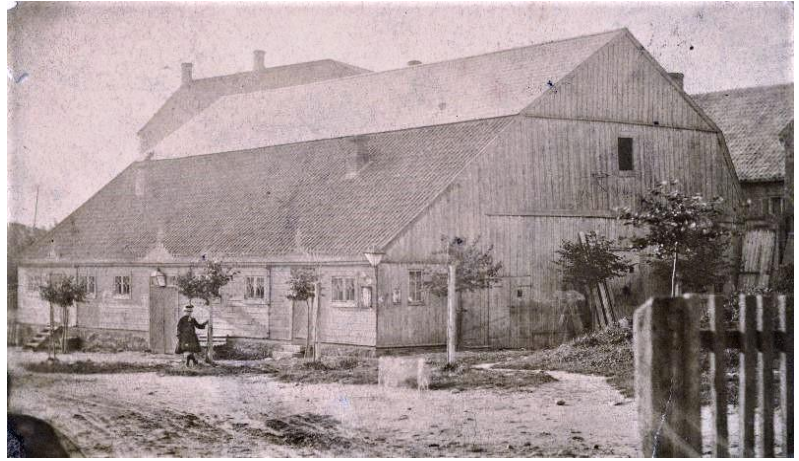

Figure 59: map of Thalia with the new theatre building 1898. Lantmäteriets historiska kartarkiv.

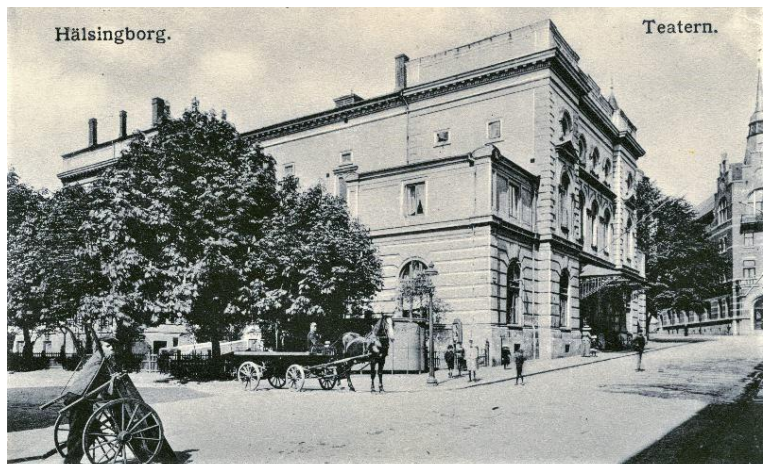

Figure 60: teaterladan in the 1870s. Photographer Hanna Nodermann. Helsingborgs museum.

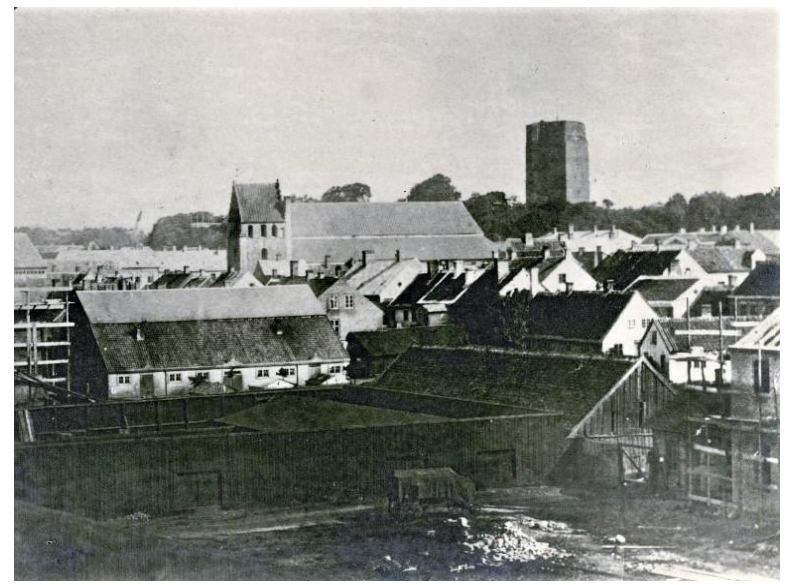

Figure 61: Helsingborg theatre in 1910. Helsingborgs museum.

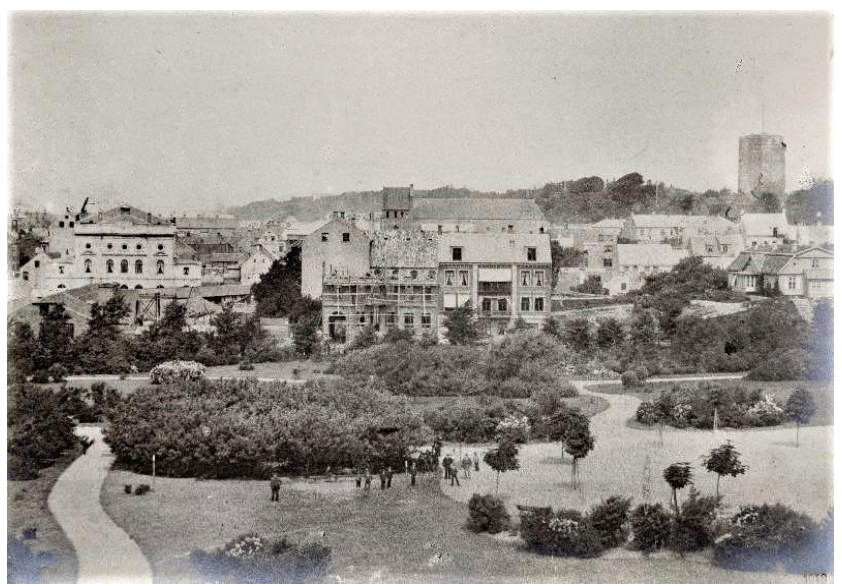

Figure 62: a view over Helsingborg with teaterladan on the left, St. Maria church center, Kärnan on the right in with Kärnan on the right and the
the background, and Ruuthska bruket in the foreground. 1883 . Helsingborgs museum.

Figure 63: view from the city park towards Trädgårdsgatan 1870s. Helsingborgs museum. 
An excavation of the site was conducted in 1984 and 1985 (RAÄ dnr. 3858/84 and 985/88) by UV-Syd (Löfgren, 1992). In October 1984, five test trenches with the total length of $58.5 \mathrm{~m}$ were excavated across the site. The western half of the site was found to be under the medieval sea level, but the eastern half contained a medieval cultural layer. An additional three test trenches $45.5 \mathrm{~m}$ in length were excavated in 1985 , to complete the layout of the site and to determine the extent of the pre-1600s shoreline. The excavation determined that the shoreline was gradually filled from medieval times up until the 1600s.

The 1985 excavation focussed on a $360 \mathrm{~m}^{2}$ area along Bruksgatan on the eastern side of the site which was earlier determined to have been above the medieval shoreline. The cultural layer was found to consist of four distinct phases.

Phase 1: medieval use of the shoreline, with finds of charcoal, sherds of older blackware, proto-stoneware, and medieval redware, three unidentifiable coins, two bone combs and postholes indicating a simple structure with the same orientation as the later buildings. Ceramic fragments date the phase to 1200-1300s.

Phase 2: several 1300s buildings, one of them with a wooden floor made out of boat planks. The building, which was destroyed in a fire, contained a large number of rivets. Next to it was a 40 $\mathrm{m} 2$ dwelling with a kitchen with brick floor and oven. A ceramic spindle whorl was found in the corner of the house. North of this building were a stone paved yard and another dwelling with a wooden floor and an oven, however most of it extended beyond the excavation trench. The majority of the finds were stoneware with $43 \%$ of the total ceramic finds. Three coins were found in this phase of which one could be identified and dating to 1241-1377.

Phase 3: a building in place of the previous building from phase 2 with remains of charred wood at the floor level and a stone paved area. The house contained another 1241-1377 coin. Several ceramic sherds date the building to the late 1300s-1400s.

Phase 4: the newest layers from 1400-1600s were for the most part dug away in the mid-1600s with the construction of Landskrona bastion in this location. The finds contained a coin dating to $1633-1654$, a drinking glass fragment, tiles, tobacco pipes and post-medieval redware.

\section{Finds from Thalia 8}

The finds list contains 253 objects, of which 221 are from the main excavation and the rest from the preliminary excavations. The 221 listed objects consist of 737 finds. The largest group of finds is younger blackware ceramic sherds. The majority of ceramic finds were found in phase 1 , despite the absence of any permanent buildings during this phase. A total of nine coins were found, of which four could be identified: two from the Danish civil war 1241-1377, one Swedish $1 / 4$ Öre from Queen Christina's reign 1633-1654, and one Swedish $1 / 4$ shilling from 1806 . Among the finds were also two iron keys from phase 1, a decorated bone comb in phase 1 dating to the late 1200s, another comb, a spindle whorl and a double buckle in phase 2, as well as a medieval horseshoe, two knives, and other metal objects such as rivets and fittings. Phase 4 contained 16 tobacco pipes and six tile fragments. 
Table 5. Ceramic finds from Thalia 8.

\begin{tabular}{|c|c|c|c|}
\hline Type & Weight (g) & Count & Percentage \\
\hline blackware & 3009 & 146 & $30.60 \%$ \\
\hline medieval redware & 1450 & 113 & $14.70 \%$ \\
\hline post-medieval redware & 3890 & 217 & $39.50 \%$ \\
\hline proto-stoneware & 360 & 36 & $3.70 \%$ \\
\hline stoneware & 1091 & 65 & $11.10 \%$ \\
\hline faience & 42 & 5 & $0.40 \%$ \\
\hline Total & 9842 & 582 & $100 \%$ \\
\hline
\end{tabular}

Ceramic type by weight, Thalia 8

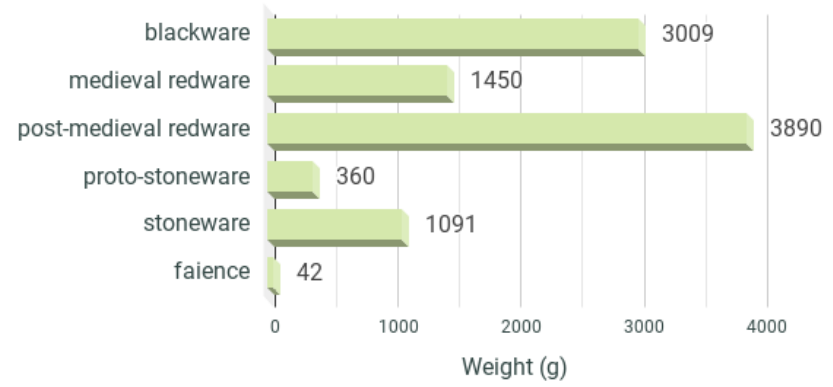

Figure 64: ceramic finds from Thalia 8.

Ceramic type by count of sherds, Thalia 8

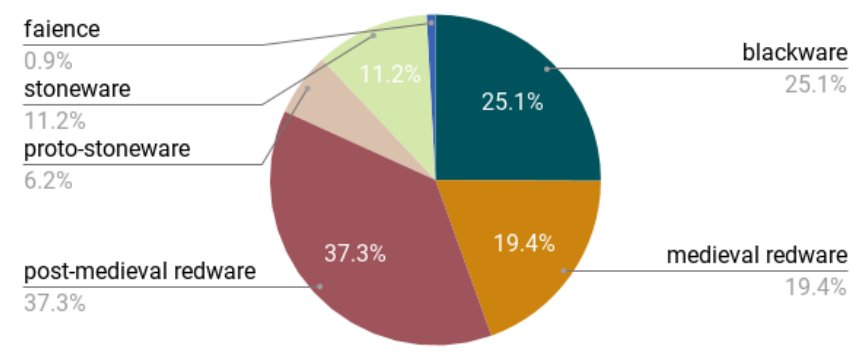

Figure 65: ceramic finds from Thalia 8. 


\section{Kärnan Mellersta 9}

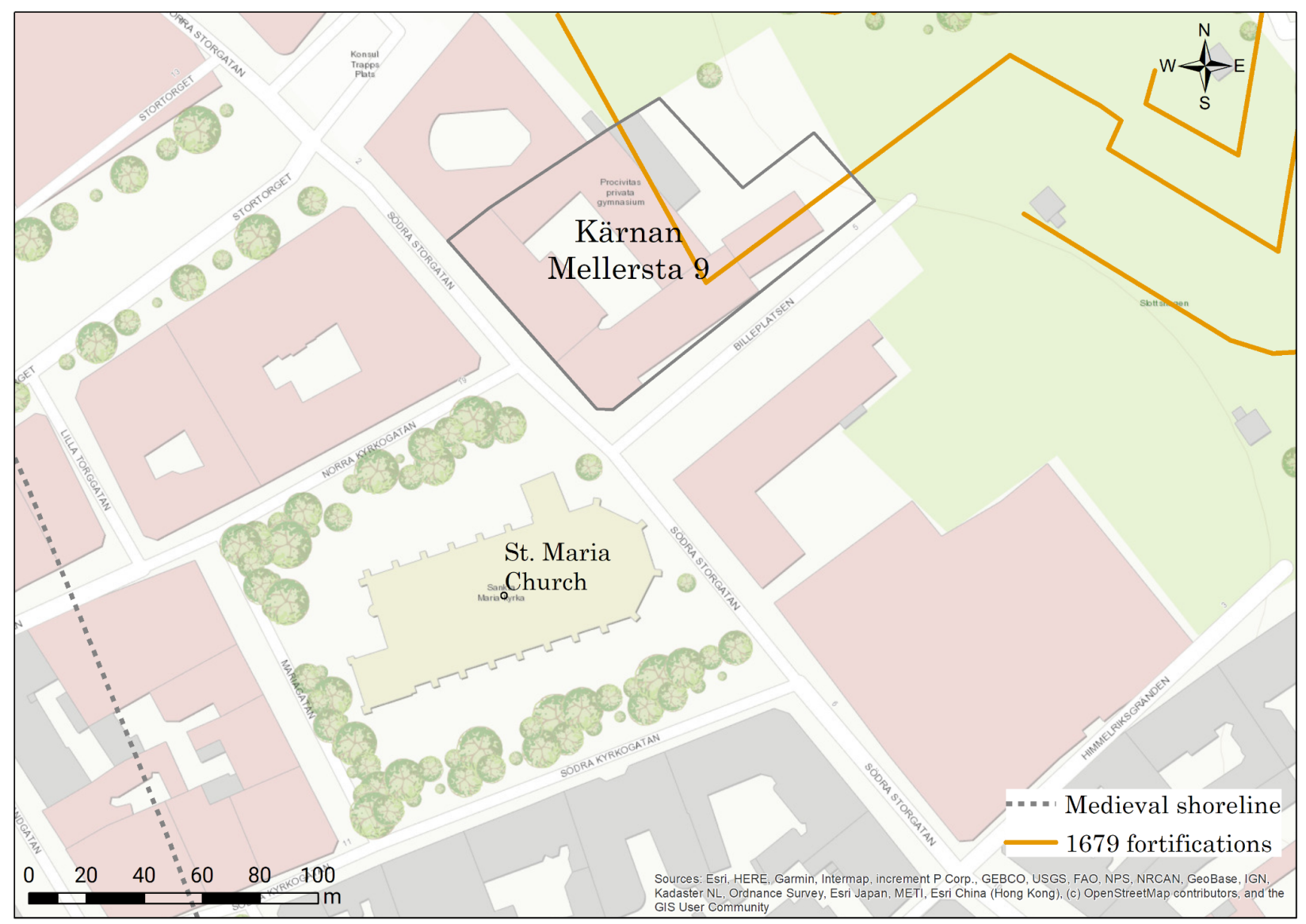

Figure 66: map of Kärnan Mellersta 9 block.

Kärnan Mellersta block is likely the oldest built up area in the lower town, directly under Landborgen, where the main road from the upper town with its medieval castle, churches, and monastery led down towards St. Maria church and the shore. The neighbourhood around St. Maria church was the late medieval centre of the town. The older town hall, which was demolished and burnt down in 1679, stood directly south of the church, in the modern day Tor block. Storgatan, which during the Danish period was called Adelgade, was the major transport artery entering the town from the south, from Landskrona, Lund, and Malmö. Until the 1600s, the town market was held along Storgatan to the north and south of St. Maria church.

Between 1651 and the early 1690s, the Kärnan Mellersta block and Billeplatsen were the site of Axeltorg, one of the main markets in the city (Wihlborg, 1981). The southwestern fortification bastion, Carl Gustaf, was situated above the block. The two timber frame buildings along Billeplatsen are part of a merchant house from the late 1700s. The building on the corner of Billeplatsen and Södra Storgatan is from 1827, with additions built in 1885-91.

Archaeological excavations in the street of Billeplatsen have taken place in 1914, 1939-40, 1955-57, 1975 (Wihlborg, 1981), 1979-82, and 2017 (Bolander and Larsson, 2017). In 1988 (RAÄ dnr. 3334/88) and 1991 (RÄ̈ dnr. 3406/91), UV-Syd conducted excavations at Kärnan Mellersta 9 due to the construction of a basement and a parking garage, which would involve 
dismantling and reassembling parts of the timber frame buildings. The excavations found remains of house foundations and packed stone layers, the oldest of them dating to the 1200s, brick walls, a 1600s cellar and two human burials near the western edge of the site, belonging to the St. Maria church medieval cemetery (Löfgren, 1992a; Bolander and Larsson, 2017).

\section{Finds from Kärnan Mellersta 9}

The Lund University Historical Museum lists 297 finds from Kärnan Mellersta 9 with inventory number 30046. Of those, 136 are medieval and early modern ceramic objects, six are coins, 49 are metal objects and 43 are human or animal bone.

Due to the lack of other data about these finds such as weight, sherd count, dating, or type of vessel, it is not possible to directly compare them with the other Helsingborg sites until the opportunity arises to visit LUHM collections in person. However, I chose to include this site as an example of an older lower town location, with finds dating possibly back to the 1200 s, which is a century earlier than any of the other sites analysed in this thesis. For the finds table below, I have used the count of registered objects, rather than their weight or count of sherds; therefore the actual percentage of ceramic types when measured by weight may not match the numbers displayed here.

Table 6. Ceramic finds from Kärnan Mellersta 9.

\begin{tabular}{|c|c|c|c|}
\hline Type & & Count & Percentage \\
\hline \multirow[t]{5}{*}{ blackware } & & 34 & $26.60 \%$ \\
\hline & older blackware & 5 & \\
\hline & younger blackware & 26 & \\
\hline & Baltic ware & 2 & \\
\hline & jydepotta & 1 & \\
\hline medieval whiteware & & 1 & $0.80 \%$ \\
\hline medieval redware & & 23 & $18.00 \%$ \\
\hline \multirow[t]{3}{*}{ post-medieval redware } & & 41 & $32.00 \%$ \\
\hline & unglazed & 24 & \\
\hline & glazed & 17 & \\
\hline proto-stoneware & & 12 & $9.40 \%$ \\
\hline stoneware & & 14 & $10.90 \%$ \\
\hline faience & & 3 & $2.30 \%$ \\
\hline Total & & 128 & $100 \%$ \\
\hline
\end{tabular}



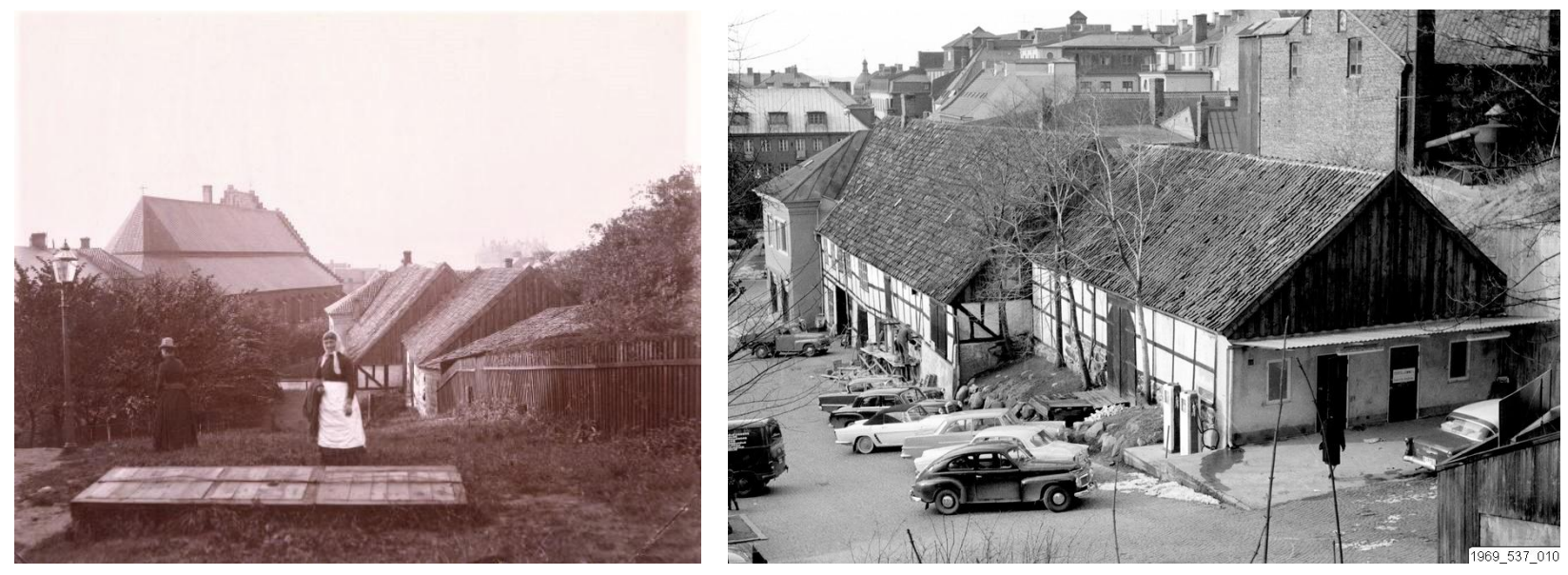

Figure 67: Billeplatsen and Kärnan Mellersta 9 looking Figure 68: Billeplatsen in the 1960s. Photographer Otto from Hallbergs trappor in the 1890s. St. Maria church onHolmström. Helsingborgs museum. the left in the background. Helsingborgs museum.

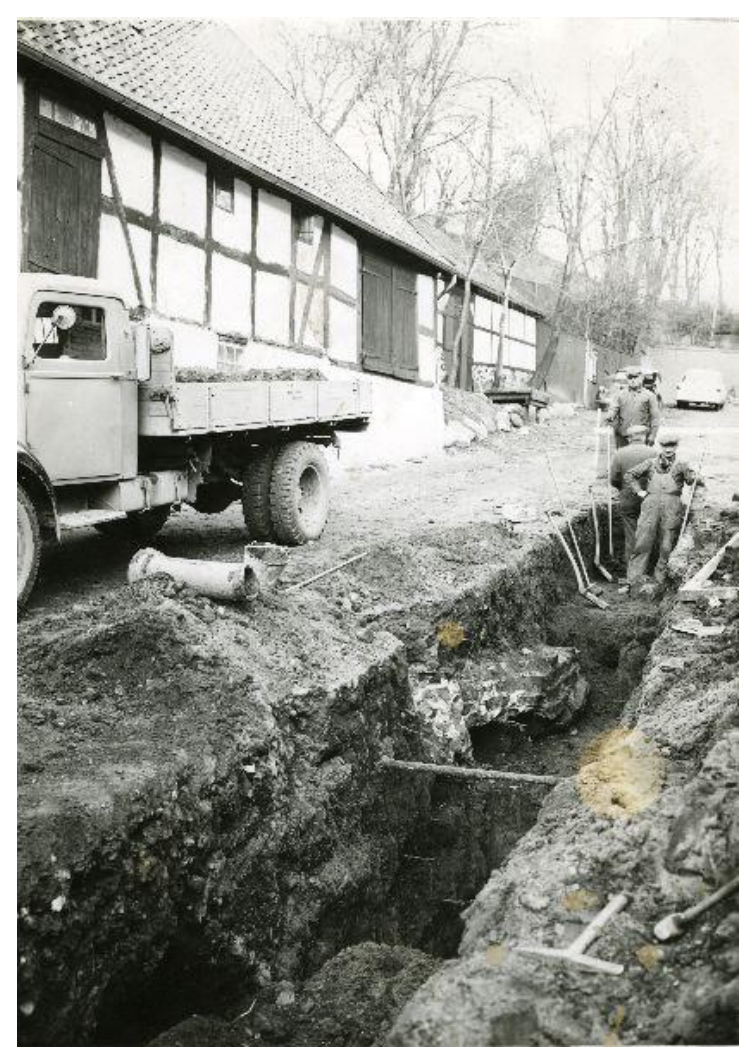

Figure 69: excavations at Billeplatsen in the 1940s. Helsingborgs museum. 


\section{Results and discussion}

Ceramic material from six sites in Helsingborg was analysed for the purposes of this thesis. One of the sites, Kärnan Mellersta 9, did not have data on the count and weight of the artefacts. Therefore, only the other five sites have been included in the totals of ceramic finds, i.e., Norden 24 and 19, Karl XI Södra 20, Färjan 4 and Thalia 8. The material from these five sites comprises 1726 sherds with the total weight 57,422 g (Table 7). The finds from Norden 19, Karl XI Södra 20 and Färjan 4 are kept at Helsingborg's Kulturmagasinet while the finds from Norden 24, Thalia 8 and Kärnan Mellersta 9 are stored at the Lund University Historical Museum. The data on the latter three sites was obtained from finds lists in the archaeological reports. The finds at Kulturmagasinet were analysed by me, in person. For these finds, the data on sherd count, weight, dimensions, glaze, decor, geographical origin and date, where identifiable, and images are available in the museum database. The data from the archaeological reports consists of keyword (e.g., jug or plate), type (e.g., BIl:4), sherd count and weight and has no information on geographic provenance of the finds.

Most finds lists contain both sherd count and weight of an object, where an object can be one or several artefacts, either fragmented or whole. The preference for using weight or sherd count in ceramic analysis could be discussed further if not for the restraints imposed by the absence of weight information for specific sherds. Only the number of sherds was used for certain imported ceramics where the weight could not be distinguished from other sherds registered with the same inventory number. When using sherd count, the result tends to be biased towards objects broken into multiple small pieces. Meanwhile, when using weight, the significance of lightweight sherds such as porcelain is diminished in favour of heavier redware and blackware finds. In this chapter I have conveyed the data available on all finds to the best of my knowledge and interpreted the results accordingly.

Post-medieval redware is the most common ceramic type in all sites, 1018 sherds with the total weight 41,319 g. 313 sherds weighing 19,385 g were identified as made either locally in Scania or Halland or elsewhere within Denmark. 217 sherds weighing 10,575 g were classified as imported, and another 488 sherds weighing 11,359 $\mathrm{g}$ had no identification of geographical origin. The ratio of identified sherds is $59 \%$ of local or Danish provenance and $41 \%$ imported goods. Among the identified imported post-medieval redware we have 66 sherds of Weser or Werra ware from Germany, 61 sherds of Dutch redware and 63 sherds of either German or Dutch light red wares, making the ratio of imported redware from the Netherlands and Germany approximately equal.

The second most common type of ceramics is stoneware, 216 sherds weighing $6525 \mathrm{~g}$. A large portion of them, 83 sherds, represent late 1700s to late 1800s brown salt-glazed stoneware made locally in Helsingborg. Fifty-nine sherds are German stoneware, ranging from 4 sherds of medieval Siegburg stoneware to fragments of 1700-1800s German mineral water bottles; 74 stoneware sherds were not identified.

The third most common type is blackware, which due to difficulties with identification includes both medieval and post-medieval blackware, possibly Baltic greyware, as well as a small number of Danish jydepotta sherds. There are a total of 179 blackware sherds weighing $3974 \mathrm{~g}$. Medieval finds are also represented by medieval redware, 120 sherds (1940 g), proto-stoneware, 36 sherds $(360 \mathrm{~g})$ and 10 sherds $(228 \mathrm{~g})$ identified on a finds list as medieval whiteware. 
Table 7. Ceramic finds from Norden 24 and 19, Karl XI Södra 20, Färjan 4 and Thalia 8.

\begin{tabular}{|c|c|c|c|c|}
\hline Type & & & Weight (g) & Sherd count \\
\hline blackware & & & 3974 & 179 \\
\hline medieval whiteware & & & 228 & 10 \\
\hline medieval redware & & & 1940 & 120 \\
\hline \multirow[t]{8}{*}{ post-medieval redware } & & & 41319 & 1018 \\
\hline & local or Danish & & 19385 & 313 \\
\hline & unidentified & & 11359 & 488 \\
\hline & imported & & 10575 & 217 \\
\hline & & Weser/Werra ware & & 66 \\
\hline & & Dutch redware & & 61 \\
\hline & & German or Dutch light ware & & 63 \\
\hline & & unidentified & & 27 \\
\hline proto-stoneware & & & 360 & 36 \\
\hline \multirow[t]{7}{*}{ stoneware } & & & 6525 & 216 \\
\hline & local, 1800s & & & 83 \\
\hline & unidentified & & & 74 \\
\hline & imported & & & 59 \\
\hline & & Siegburg stoneware & & 4 \\
\hline & & Westerwald & & 5 \\
\hline & & Other German & & 50 \\
\hline \multirow[t]{4}{*}{ tin-glazed ware } & & & 1135 & 59 \\
\hline & Dutch tin-glazed ware & & & 44 \\
\hline & Berettino ware & & & 3 \\
\hline & unidentified & & & 12 \\
\hline faience & & & 1511 & 76 \\
\hline porcelain & & & 430 & 12 \\
\hline Total & & & 57422 & 1726 \\
\hline
\end{tabular}


Total ceramic finds

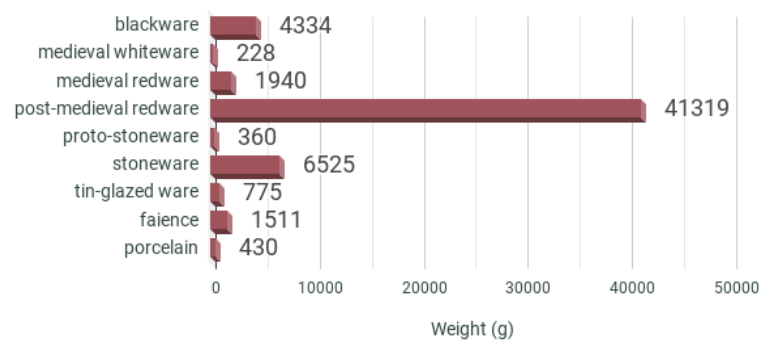

Figure 70: total ceramic finds by weight in grams.

Local redware vs. imported redware

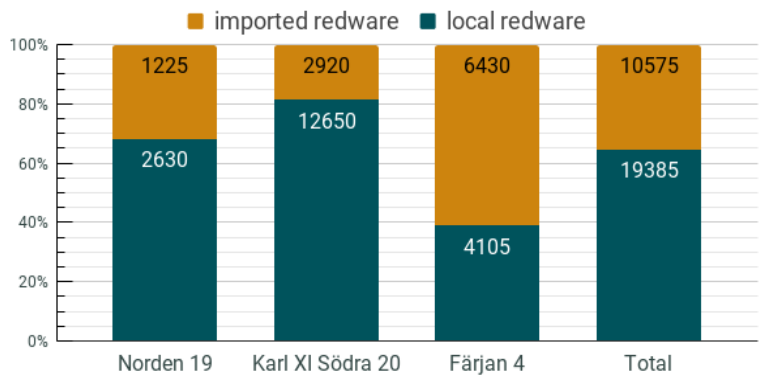

Figure 72: ratio of imported vs local post-medieval redware, by site and total of the three sites.

Norden 19 ceramics origin

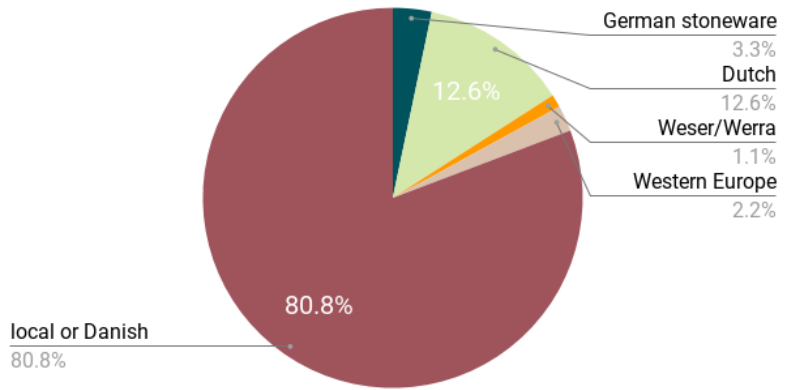

Figure 74: Norden 19 ceramics origin.
Norden 24, Norden 19, Karl XI Södra 20, Färjan 4 and Thalia 8

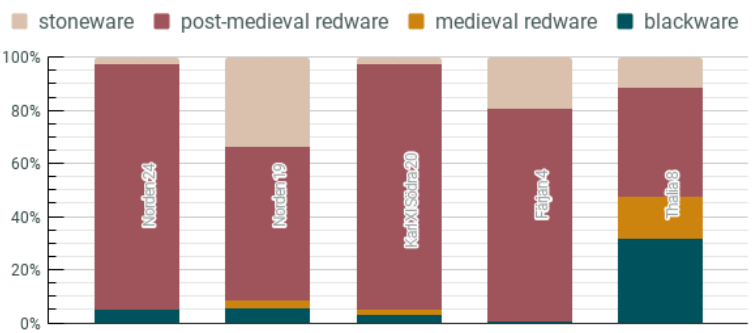

Figure 71: comparison of stoneware, post-medieval redware, medieval redware and blackware ratios by site.

Färjan 4 ceramics origin

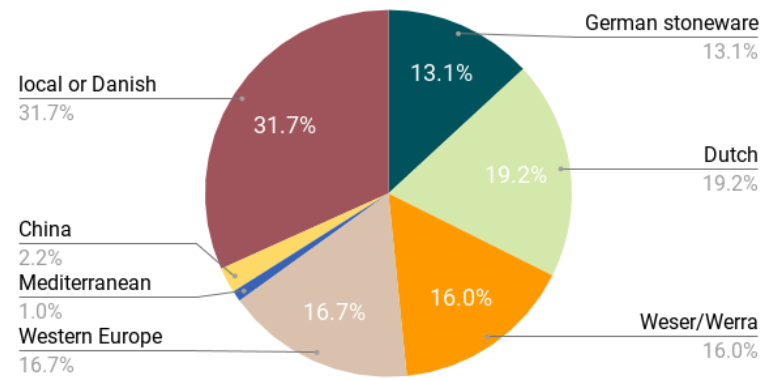

Figure 73: Färjan 4 ceramics origin.

Karl XI Södra 20 ceramics origin

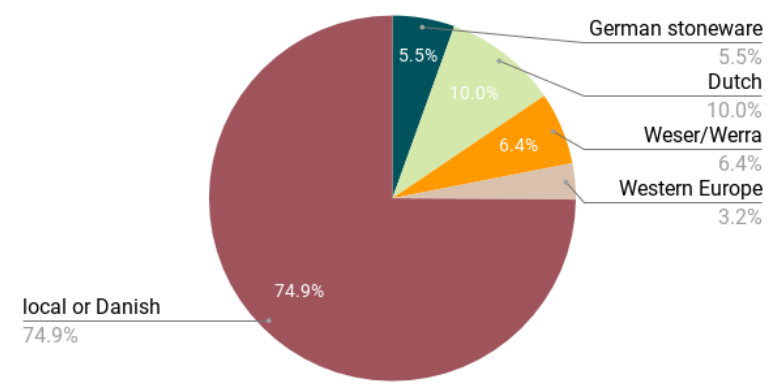

Figure 75: Karl XI Södra 20 ceramics origin. 
1500-1600s tin-glazed wares ( 59 sherds, $1135 \mathrm{~g}$ ) include 44 sherds of Dutch majolica and 3 sherds of Italian Berettino ware, as well as 12 unidentified sherds. There are no porcelain finds dating to the 1600s but the twelve fragments of porcelain include seven sherds of mid-1700s Chinese imports, one of the objects an octagonal Qianlong platter from 1736-1795 as well as fragments of Capuchin ware. The majority of faience finds are later industrial transferware and creamware and are of less relevance to the temporal scope of this research.

On a site by site basis, Thalia 8 has significantly higher proportions of both blackware and medieval redware finds (Figure 71). It is likely related to excavation methods - the $360 \mathrm{~m}^{2}$ trench was excavated for archaeological research purposes down to sterile soil level, resulting in a complete assemblage of artefacts from all excavation phases, including the oldest, medieval phase. Karl XI Södra 20 and Norden 19 had a small number of blackware and medieval redware sherds, whereas the amount of blackware at Norden 24 was similar to Norden 19 but had no medieval redware, and Färjan had one blackware sherd of unknown date and no medieval finds.

Färjan 4 presents the widest variety of ceramics in terms of their provenance as well as vessel types (Figure 73). This site is an outlier and I had significant difficulty interpreting its finds assemblage due to the uncertain dating of the site and the possibility that the majority of the finds were from a secondary or tertiary deposition. In the 1600 s the block does not appear on any of the maps of Helsingborg as containing buildings. In fact, if the early maps were accurate it was for the most part under sea level or part of the sandy shore. The 1650s coastal fortifications go either over its eastern half or directly to the east of the block. The finds from Färjan 4 contain ceramics made in the 1500-1600s, such as Weser and Werra ware plates, a fragment of a Westerwald jug, Berettino ware and early Dutch tin-glazed ware. The easiest explanation is that the finds come from demolition rubble from the buildings torn down in 1679 to the east of Färjan block which was then used as fill to expand the coastline in the late 1600s, before these blocks were built on again. However, the fill could be of a later date from any time up to the 1780s, as there is no convincing documentary evidence that the block was built up before 1788. The Färjan 4 assemblage also contains the largest amount of German mineral water bottles from the 1700-1800s which implies that the owner of the property was sufficiently wealthy to purchase imported luxury goods. The imported mid- to late $1700 \mathrm{~s}$ porcelain and faience vessels are consistent with this assessment. Färjan 4 is also the only site with a higher ratio of imported post-medieval redware. However, this data cannot be interpreted without information on the deposition circumstances of the pre-1700s finds.

If we exclude Färjan 4 from the totals when comparing geographic origins of the ceramic finds, assemblages from the two remaining sites, Norden 19 and Karl XI Södra 20, are very similar in their composition. Although, when looking at the weight of the sherds rather than their count, Karl XI Södra site has four times the amount of post-medieval redware, $15,570 \mathrm{~g}$ against $3855 \mathrm{~g}$ at Norden 19. In terms of sherd count, the assemblage from Norden 19 consists of $80.8 \%$ local or Danish wares, $12.6 \%$ Dutch, 3.3\% German stoneware, 2.2\% other Western European ceramics and $1.1 \%$ Weser or Werra ware. The results from Karl XI Södra 20 are $74.9 \%$ local/Danish, 10\% Dutch, $6.4 \%$ Weser/Werra, 5.5\% German stoneware, and 3.2\% other Western European. Combining the sherd count from both sites, the result is $77.6 \%$ local/Danish, $11.2 \%$ Dutch, $4.5 \%$ German stoneware, $4 \%$ Weser/Werra, and $2.7 \%$ other Western European wares.

This ratio is very similar to the provenance of pottery from Helsingör comprising $79 \%$ local wares, $6 \%$ Dutch ceramics, $3 \%$ German stoneware, $4 \%$ Weser or Werra ware, $1 \%$ Mediterranean ceramics, and 7\% other Western European wares (Linaa, 2020, p. 336). The sample size from 
Helsingborg is much smaller with only two of the sites offering sufficient data for this type of comparison. A further study of additional assemblages would be necessary to confirm these findings. However, for the current Helsingborg ceramics sample the similarity to Helsingör assemblage is significant. The breakdown of finds from Nya Lödöse in western Sweden is rather different, comprising only $17 \%$ locally made pottery and higher ratios of imports (Linaa, 2020, $p$. 337). The main difference from the Helsingör assemblage is the relative absence of Danish jydepotta in Helsingborg. There are 9 sherds identified as jydepotta among the finds from Thalia 8 and 18 sherds from Norden 24, as well as one find from Kärnan Mellersta 9.

The results of a ceramics comparison with Helsingör indicate that the two towns in the early modern period were indeed parts of a common market spanning the Sound. The absence of jydepotta in Helsingborg fits the pattern of a core-periphery relationship between the two towns where the bulk goods network consisting of grain, cattle and other agricultural produce moved westwards from Helsingborg to Helsingör and the prestige goods were exchanged in the opposite direction. Thus, the burghers of Helsingborg would have imported higher status cooking wares from western Europe and not rural Danish pottery. The large percentage of ceramics from the Netherlands and Germany in Helsingborg suggests that household pottery was mainly imported to Helsingborg by road and across the Sound from Helsingör. Among the finds dating to the 1600 s, there were few objects with a geographic origin that would have required shipping by sea; such ceramics appear starting in the 1700s. Transport as a service can also be considered a bulk good offered by Helsingborg in exchange for lowered taxes and additional income from the movement of goods and passengers.

To answer my second research question, I could not identify a specific change in the consumption pattern related to the transfer of power to Sweden in 1658. In fact, the earliest significant change in ceramic types appears only in the mid-1700s with faience made in Sweden and the early 1800s with the influx of stoneware vessels made at the Ruuthska bruket factory in Helsingborg. The greatest amount of local stoneware comes from the Norden 19 site. The majority of the imported 1500-1600s ceramics appear to date to before the middle of the 1600s. However, it is difficult to date the otherwise unremarkable, undecorated, brown-glazed household redwares; it would require a specialist's insight. The absence of notable change in goods traded and used by the residents of Helsingborg after 1658 hints at human agency as the deciding factor in the status of the town in relation to its core region, if preserving the material culture was, in fact, a matter of choice. On the other hand, the absence of change can also indicate that access to new goods was limited. When Helsingborg as a periphery switched its political core from Copenhagen to Stockholm, its residents continued to maintain their lifestyles, either despite restricted movement and change of trade routes or because of it.

The evidence of war and destruction is clearly visible in the archaeological record, namely, the destruction of buildings, both in relation to the construction of fortifications and the large scale demolition of the town centre in March 1679. The coin hoards from Norden block add to the picture of life in Helsingborg during the war. The burghers who deposited silver and gold in their yards had seen their hometown change hands several times in the past three decades. Their intent was to leave behind some savings in several currencies, accounting for whichever empire would be in power when they next returned because it did not yet occur to them that this last change was final and their former status could not be retained. Questions that arise from my observations are whether the attitudes of long-term residents of Helsingborg towards their property were affected by the cycle of loss, destruction and uncertainty and whether a 
consumption pattern can be identified that differs from locations untouched by wars and changes of power.

The complete destruction of Helsingborg in 1679 marked the end of an era. The town that was rebuilt and repopulated afterwards was already a different Helsingborg, more stable politically and more isolated economically. It would appear that the current focus of the history of early modern Helsingborg is on this later period, post-Swedish acquisition. The pre-1658 nature of Helsingborg, both as a sister town to Helsingör with a common market and as a major transport link between Scandinavia and the continent, has received little to no mention in archaeological literature in Sweden and Denmark. Early modern Helsingborg deserves to be brought out of obscurity in regional comparative studies, particularly regarding the rich post-medieval archaeological material from the 20th-century excavations.

\section{Conclusion}

In this thesis I have looked at the history of Helsingborg in the 1600 s, focusing on events that affected the daily lives of its population and highlighting Helsingborg as a market town and an important transport hub on the Öresund. Additionally, I have emphasised the relationship between Helsingborg and Helsingör which until 1658 were essentially two parts of the same town with a shared market whose residents were closely connected with business and family ties. I observed how the recurrent warfare between Denmark and Sweden and multiple changes of the ruling power destabilised the town and prevented its growth.

In the second part of this thesis, I presented case studies of six archaeological sites in Helsingborg and analysed the ceramic finds from excavations at these locations. A number of artefact assemblages from excavations in Helsingborg town centre in the 1920s and 1930s remain unregistered and are stored at Helsingborg's Kulturmagasinet. These finds offer a possibility for a future project to expand our knowledge on post-medieval Helsingborg and its material culture as well as to conduct a more in-depth investigation into the provenance of early modern ceramics. A future project could also connect the ceramic finds from known sites in town with other non-ceramic finds excavated and stored in various museum locations in the previous century for a more complete picture of household consumption patterns in Helsingborg. 


\section{References}

Aarhus Universitet (2011) Knud den Helliges gavebrev, 1085, danmarkshistorien.dk. Available at: https://danmarkshistorien.dk/leksikon-og-kilder/vis/materiale/knud-den-helliges-gavebrev-1085

Åberg, A. (1969) 'Den politiska historien 1658-1718', in Hälsingborgs historia IV:1

Försvenskningen. Helsingborgs Stad.

Appel, L. (2020) 'The archaeology of Elsinore and the Sand', in Urban diaspora. The rise and fall of diaspora communities in early modern Denmark and Sweden. Jutland Archaeological Society (Jutland Archaeological Society Publications, 112).

Appel, L. and Linaa, J. (2020) 'The townscape of Elsinore', in Urban diaspora. The rise and fall of diaspora communities in early modern Denmark and Sweden. Jutland Archaeological Society (Jutland Archaeological Society Publications, 112).

Arcini, C., Jacobsson, B. and Persson, B. (2006) Pestbacken. Riksantikvarieämbetet.

Augustsson, J.-E. (1985) Keramik i Halmstad ca. 1322-1619. Produktion - Distribution Funktion. Lund.

Bolander, A. and Larsson, S. (2017) Helsingborg, Gamla Staden 8:1. Rapport 2017:158. Arkeologisk förundersökning och undersökning i form av schaktningsövervakning 2017. 2017:158. Arkeologerna.

Carlsson, K. and Rosén, C. (2002) Stadsbornas kärl: Keramik i västsvenska städer från 1400-tal till 1700-tal. Göteborg University.

Chase-Dunn, C. and Hall, T. D. (1997) Rise And demise: Comparing world systems. Westview Press (New Perspectives in Sociology).

Cline, E. H. (2000) "Contested Peripheries" in world systems theory: Megiddo and the Jezreel Valley as a test case', Journal of World-Systems Research, VI(1), pp. 7-16. doi: 10/qinqq5.

Dalhede, C. (2018) 'Foreign merchants in early modern Sweden: A case of intermarriage, trade and migration', in Facing otherness in early modern Sweden: Travel, migration and material transformations, 1500-1800. The Boydell Press. 
Demuth, V. (2015) 'If sherds could tell: imported ceramics from the Hanseatic hinterland in Bergen, Norway. Producers, traders and consumers: who were they, and how were they connected?', in Everyday products in the middle ages: Crafts, consumption and the individual in Northern Europe c. AD 800-1600. Oxbow Books, p. 22.

Elfwendahl, M. (2018) 'Commodities, consumption and Forest Finns in central Sweden', in Facing otherness in early modern Sweden: Travel, migration and material transformations, 1500-1800. The Boydell Press.

Ersgård, L. (2018) 'Medieval and early modern towns in Sweden in a long-term perspective', in Urban variation: Utopia, planning and practice. Göteborg University, pp. 73-95.

Fagerlund, S. (2003) 'Smörkonor och rendekierlinger: Kvinnors handel mellan Helsingborg och Helsingör under försvenskningsperioden', in Da Østdanmark blev Sydsverige: Otte studier $i$ dansk-svenske relationer i 1600-tallet. Skippershoved (Skånsk senmedeltid och renässans, 19), pp. 81-90.

Frandsen, K.-E. and Johansen, J. Chr. V. (eds) (2003) Da Østdanmark blev Sydsverige: Otte studier i dansk-svenske relationer i 1600-tallet. Skippershoved (Skånsk senmedeltid och renässans, 19).

Gaimster, D. (1997) German stoneware 1200-1900: Archaeology and cultural history. British Museum Press.

Galaty, M. L. (2011) 'World-systems analysis and anthropology: A new détente?', Reviews in Anthropology, 40(1), pp. 3-26. doi: 10/ftrv2r.

Gosden, C. (2004) Archaeology and colonialism: Cultural contact from 5000 BC to the present. Cambridge University Press.

Gustaffson, H. (2003a) 'Att göra svenskar av danskar? Den svenska integrationspolitikens föreställningsvärld 1658-1693', in Da Østdanmark blev Sydsverige: Otte studier i dansk-svenske relationer i 1600-tallet. Skippershoved (Skånsk senmedeltid och renässans, 19), pp. 31-60.

Gustaffson, H. (2003b) 'Integration, interaktion och identiteter i den östdanska övergången till Sverige', in Da Østdanmark blev Sydsverige: Otte studier i dansk-svenske relationer i 1600-tallet. Skippershoved (Skånsk senmedeltid och renässans, 19), pp. 7-10. 
Hall, T. D., Kardulias, P. N. and Chase-Dunn, C. (2011) 'World-systems analysis and archaeology: Continuing the dialogue', Journal of Archaeological Research, 19(3), pp. 233-279. doi:

10/b7q6kt.

Hansen, K. (2020) Medeltida stadsaristokrati: Världsligt frälse i de skänska landskapens städer. Lund University (Lund studies in medieval archaeology, 21).

Helsingborgs stadsteater (no date) Helsingborgs stadslexikon. Available at: https://stadslexikon.helsingborg.se/helsingborqs-stadsteater/.

Jennbert, K. (2010) 'Helsingborgstraktens förhistoria', in Ulfsparre, A. C., Helsingborgs historia VIII:2 Landsbygden. Helsingborgs Stad (Helsingborgs historia, VIII).

Johannesson, G. (1969a) 'Förvaltningen', in Hälsingborgs historia III:2 Dansktidens slutskede. Helsingborgs Stad.

Johannesson, G. (1969b) 'Näringslivet', in Hälsingborgs historia III:1 Dansktidens slutskede. Helsingborgs Stad.

Johannesson, G. (1969c) 'Politisk historia', in Hälsingborgs historia III:2 Dansktidens slutskede. Helsingborgs Stad.

Johannesson, G. (1969d) 'Stadens näringsliv och ekonomi', in Hälsingborgs historia IV:2 Försvenskningen. Helsingborgs Stad.

Johannesson, G. (1969e) 'Stadens styrelse och förvaltning', in Hälsingborgs historia IV:1 Försvenskningen. Helsingborgs Stad.

Johannesson, G. (1979) 'Frihetstiden och gustavianska tiden (1718-1809): Näringslivet', in Helsingborgs historia V:1 Perioden 1718-1862. Helsingborgs Stad.

Johansson, M. and Århem, B. (2015) 'Medeltidens, renässansens och barockens keramik', in Keramik \& porslin i Sverige genom 7000 år. Carlsson Bokförlag.

Johnson, M. (1996) An archaeology of capitalism. Blackwell Publishers.

Jonsson, K. (2018) ‘Myntmetaller som ståndsmarkörer’, Myntstudier, 2018(1), pp. 1-17.

Kardulias, P. N. and Hall, T. D. (2008) 'Archaeology and world-systems analysis', World Archaeology, 40(4), pp. 572-583. doi: 10/djz6mv. 
Karlsgatan (no date) Helsingborgs stadslexikon. Available at:

https://stadslexikon.helsingborg.se/karlsgatan/.

Kriig, S. (1992) Rapport. Slutundersökning. Kv Norden 24, Helsingborg, Skåne, 1988. 4168/88.

Riksantikvarieämbetet, Byrån för arkeologiska undersökningar.

Kristensen, R. S. (2014) 'Made in China: Import, distribution and consumption of Chinese porcelain in Copenhagen c. 1600-1760', Post-Medieval Archaeology, 48(1), pp. 151-181. doi: 10/giwfpd.

Kruse, T. (ed.) (2020) Kärnan: Från dansk riksborg till svenskt kulturarv. Helsingborgs museer (Kring Kärnan, 41).

Kuusela, J.-M., Nurmi, R. and Hakamäki, V. (2018) 'Unhierarchical and hierarchical core-periphery relations: North fennoscandian trade network from the middle ages to the post-sixteenth century', American Anthropologist, 120(4), pp. 765-780. doi: 10/gf5vgq.

Linaa, J. (2016) Urban consumption: Tracing urbanity in the archaeological record of Aarhus C. AD 800-1800. Jutland Archaeological Society (Jutland Archaeological Society Publications, 94).

Linaa, J. (2020) Urban diaspora. The rise and fall of diaspora communities in early modern Denmark and Sweden. Jutland Archaeological Society (Jutland Archaeological Society Publications, 112).

Linder, K. (2015) 'Ostindisk porslin i Sverige', in Keramik \& porslin i Sverige genom 7000 år. Carlsson Bokförlag.

Lindquist, G. (2015) 'Krukmakarnas lergods', in Keramik \& porslin i Sverige genom 7000 år. Carlsson Bokförlag.

Löfgren, A. (1986) 'Arkeologiska underökningar i kvarteren Thalia, Tor och Ruuth', in Kring Kärnan 16. Helsingborgs museer (Kring Kärnan, 16).

Löfgren, A. (1992a) Rapport. Förundersökning medeltid-nyare tid. Kv Kärnan mellersta 9, Helsingborg, Skåne, 1991. 589/92. Riksantikvarieämbetet, Byrån för arkeologiska undersökningar.

Löfgren, A. (1992b) Rapport. Kv Thalia 8 m fl, Helsingborg, Skåne, 1984. Arkeologiska förundersökningar och slutundersökning. 2372/92. Riksantikvarieämbetet, Byrån för arkeologiska undersökningar. 
Mårtensson, T. (1969a) 'Efterskörd från ett fältslag', in Hälsingborgs historia IV:1 Försvenskningen. Helsingborgs Stad.

Mårtensson, T. (1969b) 'Fästningen', in Hälsingborgs historia III:2 Dansktidens slutskede. Helsingborgs Stad.

Mårtensson, T. (1969c) 'Hälsingborgs befästning under svensk tid', in Hälsingborgs historia IV:1 Försvenskningen. Helsingborgs Stad.

Nordin, J. M. (2020) The Scandinavian early modern world: A global historical archaeology. Routledge. doi: 10.4324/9780429328176.

Nyström, B. (ed.) (2015) Keramik \& porslin i Sverige genom 7000 år. Carlsson Bokförlag. Ohlsson, K. (ed.) (2009) Museum i 100 år: Helsingborgs museum från 1909. Helsingborgs museer (Kring Kärnan, 37).

Poulsen, B. (2004) 'Trade and consumption among late medieval and early modern Danish peasants', Scandinavian Economic History Review, 52(1), pp. 52-68. doi: 10/fzhz88.

Rosén, C. (2004) Stadsbor och bönder: Materiell kultur och social status i Halland från medeltid till 1700-tal. Stockholm: Almqvist \& Wiksell International (Lund studies in medieval archaeology, 35).

Roth, T. (2020) 'Helsingborgs befästningar: Modernisering och rasering under 1600-talet', in Kärnan: Från dansk riksborg till svenskt kulturarv. Helsingborgs museer (Kring Kärnan, 41).

Tagesson, G. (2018) 'Houses of wood, houses of stone: On constructing a modern town in early modern Kalmar', in Facing otherness in early modern Sweden: Travel, migration and material transformations, 1500-1800. The Boydell Press.

Tagesson, G. and Jeppsson, A. (2015) 'Varmt och skönt - och iögonfallande modernt: Kakelugnar som social konsumtion i det tidigmoderna Sverige', Förnvännen, 110(2), pp. 111-125.

Tegnér, A. (2015) 'Blommande fajanser och stramt flintgods', in Keramik \& porslin i Sverige genom 7000 år. Carlsson Bokförlag.

Thomasson, J. (1997) 'Private life made public: Aspects of the emergence of burghers in medieval Denmark', in Visions of the past: Trends and traditions in Swedish medieval archaeology. (Lund studies in medieval archaeology, 19). 
Wallerstein, I. (2004) World-systems analysis: An introduction. Duke University Press.

Wihlborg, A. (1981) Helsingborg. Riksantikvarieämbetet och Statens Historiska Museer (Medeltidsstaden, 32).

Wihlborg, A. (1992) Kv Karl XI norra 9-16, Helsingborg, Förnlämning 42, Skåne, 1981 och 1984. Arkeologisk förundersökning och slutundersökning. Riksantikvarieämbetet, Byrån för arkeologiska undersökningar.

Wolf, J. L. (1654) Encomion Regni Daniæ. Det er: Danmarckes Riges Lof, oc dets høyloflige Konge Riges tilhørige Provinciers, Øers, Kongelige Slotters oc Festningers, Herre-Sæders, oc andre prectige Bygningers Beskrifvelse. Copenhagen. Available at:

https://www.digitale-bibliothek-mv.de/viewer/resolver?urn=urn:nbn:de:gbv:9-g-4888463. 